GERLANE DE MEDEIROS COSTA

Estudo histomorfológico e análise dos perfis celulares do rim cefálico, fígado, baço e timo do Piaractus mesopotamicus (Holmberg, 1887, Teleósteo, Characidae), pacu

São Paulo 


\section{Estudo histomorfológico e análise dos perfis celulares do rim cefálico, fígado, baço e timo do Piaractus mesopotamicus (Holmberg, 1887, Teleósteo, Characidae), Pacu}

Dissertação apresentada ao Programa de Pós-Graduação em Anatomia dos Animais Domésticos e Silvestres da Faculdade de Medicina Veterinária e Zootecnia da Universidade de São Paulo para obtenção do título de Mestre em Ciências

Departamento:

Cirurgia

Área de concentração:

Anatomia dos Animais Domésticos e Silvestres

Orientador:

Prof. Dr. José Roberto Kfoury Junior

SÃO PAULO 
Autorizo a reprodução parcial ou total desta obra, para fins acadêmicos, desde que citada a fonte.

DADOS INTERNACIONAIS DE CATALOGAÇÃO-NA-PUBLICAÇÃO

(Biblioteca Virginie Buff D’Ápice da Faculdade de Medicina Veterinária e Zootecnia da Universidade de São Paulo)

\section{Costa, Gerlane de Medeiros}

Estudo histomorfológico e análise dos perfis celulares do rim cefálico, fígado, baço e timo do Piaractus mesopotamicus (Holmberg, 1887, Teleósteo, Characidae), pacu / Gerlane de Medeiros Costa. - São Paulo:

G. M. Costa, 2007. $133 \mathrm{f}$ : : il.

Dissertação (mestrado) - Universidade de São Paulo. Faculdade de Medicina Veterinária e Zootecnia. Departamento de Cirurgia, 2007.

Programa de Pós-Graduação: Anatomia dos Animais Domésticos e Silvestres.

Área de concentração: Anatomia dos Animais Domésticos e Silvestres.

Orientador: Prof. Dr. José Roberto Kfoury Junior.

1. Células hematopoiéticas. 2. Piaractus mesopotamicus. 3. Órgãos linfóides. I. Título. 


\section{UNIVERSIDADE DE SÃO PAULO \\ Faculdade de Medicina Veterinária e Zootecnia \\ Comissão Bioética}

\section{CERTIFICADO}

Certificamos que o Projeto intitulado "Estudo histomorfológico e análise dos perfis celulares do rim cefálico, fígado, baço e timo do Piaractus mesopotamicus (Holmberg, 1887, Teleosteo, Characidae), pacu", protocolado sob o n894/2006, utilizando 30 (trinta) pacus, sob a responsabilidade do Prof. Dr. José Roberto Kfoury Júnior, está de acordo com os princípios éticos de experimentação animal da Comissão de Bioética da Faculdade de Medicina Veterinária e Zootecnia da Universidade de São Paulo e foi aprovado em reunião do dia 17/05/2006.

(We certify that the Research "Histomorphologic study and analysis of head kidney, liver, spleen and thymus's cellular profiles of the Piaractus mesopotamicus (Holmberg, 1887, Teleosteo, Characidae), pacu", protocol number 894/2006, utilizing 30 (thirty) pacu, under the responsibility of Prof. Dr. José Roberto Kfoury Júnior, agree with Ethical Principles in Animal Research adopted by Bioethic Commission of the Faculty of Veterinary Medicine and Zootechny of University of São Paulo and was approved in the meeting on the 17th of May of 2006).

São Paulo, 18 de maio de 2006

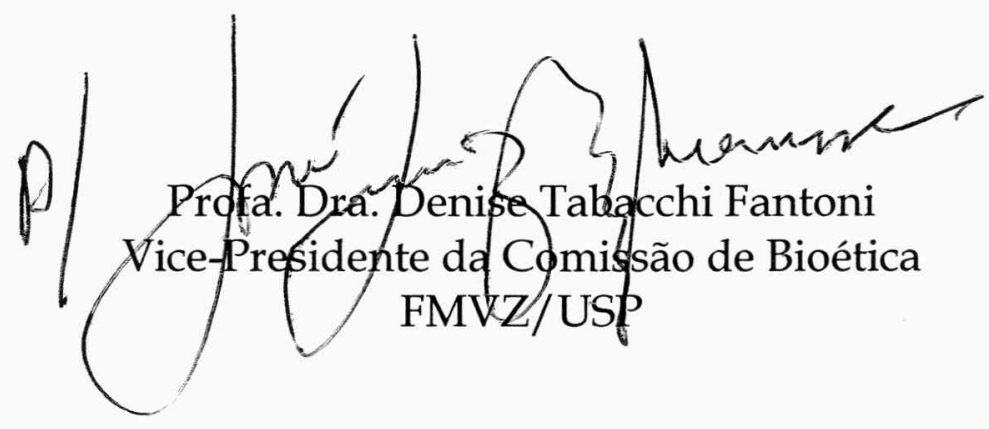




\section{FOLHA DE AVALIAÇÃO}

Nome: COSTA, Gerlane de Medeiros

Título: Estudo histomorfológico e análise dos perfis celulares do rim cefálico, fígado, baço e timo do Piaractus mesopotamicus (Holmberg, 1887, Teleósteo, Characidae), pacu

Dissertação apresentada ao Programa de PósGraduação em Anatomia dos Animais Domésticos e Silvestres da Faculdade de Medicina Veterinária e Zootecnia da Universidade de São Paulo para obtenção do título de Mestre em Ciências

Data:

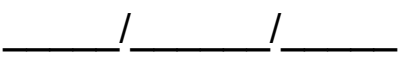

Banca examinadora

Prof. Dr.:

Assinatura:

Prof. Dr.:

Assinatura:

Prof. Dr.:

Assinatura:
Instituição:

Julgamento:

Instituição:

Julgamento:

Instituição:

Julgamento: 


\section{DEDICATÓRIA}

Às minhas três filhas Talita, Mariana e Iara, que são meu orgulho, alegria e os maiores tesouros da minha vida, por sempre me acompanharem e nunca terem, em nenhum momento, questionado ou cobrado a minha ausência.

Ao meu sogro e sogra, Edézio Barbosa de Lima e Magali Guerreiro de Lima, pela ajuda e apoio incondicional desde o inicio, para que eu pudesse realizar este sonho e dar este passo em minha vida.

Aos meus amigos de república Juliana Braz Freire e André Luiz Rezende Franciolli com os quais pude contar em todos os momentos bons e ruins, alegres e tristes, frios e quentes com muito bom humor e companheirismo. Eles foram demais.

A todos os meus amigos, e eles sabem quem são, que estiveram comigo durante esse tempo de USP me ajudando, acompanhando, apoiando, brigando, dando risada, ensinando, aprendendo, nunca esquecerei vocês. 


\section{AGRADECIMENTOS}

À FAPESP pelo apoio financeiro.

Ao meu professor, orientador e agora amigo Dr. José Roberto Kfoury Jr., o "meu Zezinho", por acreditar e confiar em mim desde o início, me apoiando e ajudando em todas as horas que precisei dele.

Às minhas colegas de laboratório Renatinha (Renata Stecca Iunes), Ana Maria Rita (Ana Rita Lima), Jana Maria (Janaína Munuera Monteiro) e Rose Maria (Rosemary Viola Bosch) que muito me ensinaram $e$ ajudaram em meus experimentos e em minha vida durante esse tempo. Sem vocês eu não teria chegado aqui.

Ao meu grande amigo e companheiro de sala de cubas, sala de aula prática, nas horas que as peças chegavam para preparar, na hora de arranjar peças $e$ principalmente na hora em que precisei de um amigo Edinaldo Ribas Farias (o Indio). Esse negão foi muito.

À Piscicultura XV de novembro - São João da Boa Vista-SP, por ter me cedido os exemplares de excelente qualidade de pacu, sem os quais eu não teria realizado a minha pesquisa.

Ao Jailton, funcionário responsável pelos tanques da piscicultura, por em nenhum momento ter deixado de me atender. Estando sempre com um sorriso no rosto e com extrema boa vontade, mesmo nas manhãs geladas dos finais de semana que 0 fiz entrar nos tanques. 
À professora Dra. Maria Angélica Miglino por ter criado este programa e eu poder ter estado, assim como muitos outros, em um dos melhores programas de pós-graduação do país.

Aos professores Dr. Francisco Javier Hernandez-Blazquez, Dr. Pedro Primo Bombonato, Dra. Tatiana Carlesso e a Dra. Ana Flávia de Carvalho, pela ajuda e esclarecimentos que me deram neste trabalho.

Aos amigos do departamento Maicon Barbosa da Silva, Jaqueline Martins de Santana, Diogo Palermo, Ronaldo Agostinho da Silva, Sandra F. Affonso, Maise Jesus de Oliveira, João do Carmo Freitas, Raimundo Leal de Sousa e Fátima de Lourdes Minare por ter podido sempre contar com eles.

A todos os meus colegas de pós-graduação que me acompanharam, em especial a Emerson T. Fioretto, que me ajudaram e apoiaram durante este período e neste trabalho.

A todos os que, de alguma forma me ajudaram e contribuíram para realização deste trabalho.

Muito obrigada. 


\section{RESUMO}

COSTA, G. M. Estudo histomorfológico e análise dos perfis celulares do rim cefálico, fígado, baço e timo do Piaractus mesopotamicus (Holmberg, 1887, Teleósteo, Characidae), pacu. [Histomorphologic study and analysis of the cellular profiles of the head kidney, liver, spleen and thymus of Piaractus mesopotamicus (Holmberg, 1887, Teleostei, Characidae), pacu]. 2007. 133f. Dissertação (Mestrado em Ciências) - Faculdade de Medicina Veterinária e Zootecnia, Universidade de São Paulo, São Paulo, 2007.

O pacu, Piaractus mesopotamicus, é um teleósteo da Família Characidae, intensivamente cultivado no Brasil por causa de sua rusticidade, crescimento rápido e fácil adaptação, além de seu excelente sabor. Para uma melhor produção de peixes, informações sobre seu sistema imunológico incluindo a histologia dos órgãos linfóides se faz necessária. Sendo assim, o objetivo deste estudo foi descrever histomorfologicamente os órgãos linfóides: rim cefálico, fígado, baço e timo do Piaractus mesopotamicus, analisando os perfis celulares de cada órgão. Foram utilizados 30 animais juvenis, com idade que variaram entre 5 meses a um ano, com peso médio de $588.1 \mathrm{~g}$ e comprimento total médio de $27,51 \mathrm{~cm}$. Os órgãos foram pós-fixados em solução de paraformaldeído 4\% e Karnovsky, depois desidratados, diafanizados em xilol e incluídos em parafina. Os cortes foram obtidos com uma espessura de $4 \mu \mathrm{m}$ e corados em hematoxilina-eosina. Os esfregaços sanguíneos foram corados em Giemsa-May Grünwald para microscopia de luz. Para microscopia eletrônica de transmissão as amostras fixadas em Karnovsky foram lavadas em sacarose e pósfixadas em tetróxido de ósmio 1\%, desidratadas e emblocadas em resina Spurr. 0 resultado da análise macroscópica mostra que a distribuição do rim, rim cefálico, timo, fígado e baço são as mesmas encontradas na maioria dos teleósteos. Quanto à forma desses órgãos, o fígado apresentou uma variação anatômica na forma e números de lobos, sendo constituído por três lobos. O rim apresentou uma forma em "H", onde a região central deste se expandia sobre a bexiga natatória. O rim cefálico, em animais com idade mais avançada, se apresentou como uma dilatação na região cranial do rim, se mostrando bem visível. O timo e o baço apresentaram localização e forma similares aos de outros teleósteos. A microscopia mostrou similaridades entre os órgãos do Piaractus mesopotamicus e outros teleósteos. Na microscopia 
eletrônica de transmissão foram observadas similaridades ultraestruturais das células encontradas no rim cefálico, fígado, timo e baço e as já descritas em peixes teleósteos. Hemácias, trombócitos, linfócitos, eosinófilos e células granulocíticas especiais encontrados no sangue periférico, tanto de animais jovens quanto dos animais com idade mais avançada, foram os mesmos tipos celulares descritos na literatura de teleósteos. Observando nossos resultados concluímos que histologicamente os órgão linfóides de Piaractus mesopotamicus são similares aos de outros teleósteos e comparando os resultados de microscopia de transmissão concluímos que as estruturas encontradas nas nossas análises são as mesmas das descritas em outras espécies. Os resultados das nossas observações macroscópicas mostraram que o pacu é uma espécie que apresenta algumas características morfológicas singulares e que podem estar ligadas ao tipo de alimentação e a adaptações evolutivas. Esses achados demonstram que a anatomia dos órgãos de peixes e suas variações precisam ser analisados e correlacionados com suas funções e forma de vida de cada espécie.

Palavras-chave: Células hematopoiéticas. Piaractus mesopotamicus. Órgãos linfóides. 


\begin{abstract}
COSTA, G. M. Histomorphologic study and analysis of the cellular profiles of the head kidney, liver, spleen and thymus of Piaractus mesopotamicus (Holmberg, 1887, Teleostei, Characidae), pacu. [Estudo histomorfológico e análise dos perfis celulares do rim cefálico, fígado, baço e timo do Piaractus mesopotamicus (Holmberg, 1887, Teleósteo, Characidae), pacu.]. 2007. 133 f. Dissertação (Mestrado em Ciências) - Faculdade de Medicina Veterinária e Zootecnia, Universidade de São Paulo, São Paulo, 2007.
\end{abstract}

Piaractus mesopotamicus (Pacu) is a fish from the Characidae Family, it is intensively culture in Brazil because of its rusticity, easy raising and adaptation, besides its excellent flavour. In order to produce a healthy fish, information on its immunological system, including the histology of the lymphoid organs is needed. Therefore, the objective of this study is to describe histomorphologicaly the lymphoid organs: head kidney, liver, spleen and thymus of the Piaractus mesopotamicus, analyzing the cellular profiles of each organ. Thirty young animals, with age varying between 5 months to a year, with average weight and total length of $588.1 \mathrm{~g}$ and a $27.51 \mathrm{~cm}$, respectively, were used. The organs were fixed in $4 \%$ paraformaldehyde solution, and Karnovsky, afterwards dehydrated, diafanized in xilol and included in paraffin. Four $\mu \mathrm{m}$ sections were obtained and stained with hematoxilin-eosin. Blood smears were stained with Giemsa-May Grünwald for light microscopy. Samples for transmission electric microscopy were fixed in Karnovsky, washed in sacarose and post-fixed with osmium tetroxide 1\%, dehydrated and embedded in resin Spurr. The macroscopic analysis show that the localization of the kidney, head kidney, thymus, liver and spleen are very similar to most of the teleosts. Some particularities were observed in the liver, which presented an anatomical variation in the shape and number of lobes, being constituted by three lobes. The kidney presented existe "H" shape, where the central region overlaps the swimming bladder. The head-kidney, in adult animals, presented an evident dilation in the cranial region of the kidney. The thymus and spleen presented a similar location and shape to that of the teleosts. The light microscopy studies showed similarities between the organs of the Piaractus mesopotamicus and other teleost fishes. The transmission electron microscopy studies showed ultrastructural similarities, of the cells from the head kidney, liver, thymus and spleen with the literature. Eritrocytes, trombocytes, lymphocytes, 
eosinophils and special granulocytic cells were found in peripheral blood of both juvenile and adult animals and were similar to the cellular profiles described in the literature to the other teleost fishes. Our studies were successful in describing the macro, micro and ultrastructure of Piaractus mesopotamicus organs and may be used as reference for further research aiming the improvement of fish health status in aquaculture.

Key-words: Hematopoietic cell. Piaractus mesopotamicus. Lymphoid organs. 


\section{LISTA DE FIGURAS}

Figura 1 - Fotografia em vista lateral do Piaractus mesopotamicus, evidenciando a disposição dos órgãos "in situ": rim (R), rim cefálico (circulo pontilhado), baço $(B)$, timo $(T)$ e fígado $(F)$.

Barra: $1 \mathrm{~cm}$. 56

Figura 2 - Fotografia dos órgãos "in situ" do Piaractus mesopotamicus. A: Visão lateral da região média do rim em forma de "H" (seta), dilatação do rim cefálico (círculo pontilhado). Animal com 8 meses de idade:fixado em formol 10\%,Barra: 1,5 cm B: Posição em decúbito dorsal, rim (circulo pontilhado) e rim cefálico (seta). Não é possivel observar uma clara distinção entre os dois órgãos. Animal com 4 meses de idade a fresco. Barra: $3 \mathrm{~cm}$. 58

Figura 3 - A: posição em decúbito dorsal nota-se a membrana que separa a cavidade celomática da cabeça (seta). Barra: $1,5 \mathrm{~cm}$. B: visão lateral do lobo dorsolateral direito do fígado $(F)$, dorsal a este lobo a bexiga natatória $(B N)$, observamos o lobo ventral evidenciando impressão do estômago (Est) e a expansão lateral do rim sobre a bexiga natatória (seta). Barra: $3 \mathrm{~cm}$. C: visão lateral esquerda do fígado evidenciando o lobo dorsolateral direito (LDD) e esquerdo (LDE) e lobo ventral (LV). Barra: $3 \mathrm{~cm}$

Figura 4 - Visão lateral direita do timo direito (círculo). Barra: $3 \mathrm{~cm}$ 62

Figura 5 - Vista lateral direita do baço (circulo pontilhado), caudalmente ao lobo dorsolateral direito (LDD), ventralmente a bexiga natatória $(B N)$ e dorsalmente a porção média da vesícula biliar (seta). Barra: $1,5 \mathrm{~cm}$. 
Figura 6 - Fotomicrografia A: no rim, glomérulos (G) e cápsula de Bowman (seta), vasos sangüíneos (V) e melanomacrófagos (círculo pontilhado) dispersos no citoplasma. Barra: $50 \mu \mathrm{m}$ B: túbulos contorcidos proximais, epitélio cúbico simples (seta) e túbulos contorcidos distais com epitélio cúbico baixo com luz central reduzida (*). Coloração HE. Barra: $40 \mu \mathrm{m}$.

Figura 7- Fotomicrografia A: região medular do rim cefálico $(R M)$ e

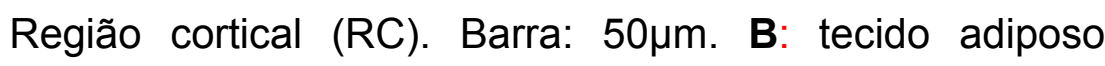
unilocular (TAU) e hemácias (círculo pontilhado). Coloração HE. Barra: $50 \mu \mathrm{m}$ 69

Figura 8 - Fotomicrografia do rim cefálico. Observar no vaso sangüíneo (seta vazia) hemácias; túbulos contorcidos proximais (estrela azul); linfócitos (seta preta); célula reticular (seta vermelha); trombócitos (seta verde); melanomacrófagos livres (seta amarela) e melano-macrófagos centrais (estrela vazia) Observar o parênquima constituído em sua maioria por células sangüíneas relativamente

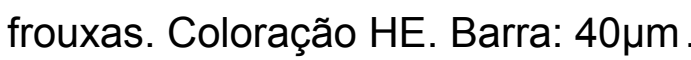

Figura 9 - Fotomicrografia do rim cefálico: Parênquima constituído na sua maioria por hemácias. Observar que a região cortical e medular são pouco distintas. Coloração HE. Barra: $40 \mu \mathrm{m}$

Figura 10 - Eletromicrografia do túbulo contorcido proximal em área de transição entre rim e rim cefálico. Na célula endotelial microvilosidades apicais (seta fina), um núcleo de formato irregular (estrela preta) com heterocromatina e eucromatina (seta azul), vacúolos eletro-densos (estrela branca) e muitas mitocôndrias $(\mathrm{m})$. Desmossomos interconectavam essas células (seta vermelha) e entre 
uma célula e outra pôde-se observar uma célula limitante (CL) Barra: $5 \mu \mathrm{m}$

Figura 11 - Eletromicrografia do parênquima do rim cefálico. Observar hemácias (seta laranja); trombócitos (seta vermelha); linfócitos (seta azul) e eosinófilos (seta preta) Barra: de $5 \mu \mathrm{m}$....... 73

Figura 12 - Eletromicrogafia de eosinófilo do rim cefálico. Observar a forma irregular da célula. Núcleo grande eucromático $(\mathrm{N})$ e um nucléolo evidente (seta branca fina). No citoplasma presença de grânulos (G), mitocôndria (seta pequena) e vacúolos (seta vermelha), Barra: $5 \mu \mathrm{m}$

Figura 13 - Eletromicrografia de protrombócito encontrado no rim cefálico. Esta célula apresentava um formato arredondado, núcleo eucromático grande em forma de ferradura (seta branca), vacúolos (seta vermelha). Barra: $2 \mu \mathrm{m}$ 75

Figura 14 - Eletromicrografia de mielócito. Observar o núcleo grande, excêntrico com eucromatina $(\mathrm{N})$. No citoplasma, presença de vacúolos (V), vesículas (seta azul), retículo endoplasmático rugoso (rer), mitocôndrias (m) e complexo de Golgi (seta larga). Barra: $2 \mu \mathrm{m}$ 76

Figura 15 - Eletromicrografia de linfócito no rim cefálico. Observar um núcleo grande $(\mathrm{N})$ com muita eucromatina. No citoplasma mitocôndrias $(m)$, alguns vacúolos (seta pequena) e material granular. Barra: $2 \mu \mathrm{m}$

Figura 16 - Eletromicrografia de uma célula tronco no rim cefálico. Observar a o formato arredondado da célula com pequenas projeções da membrana. Seu núcleo grande com reentrâncias (estrela) e um nucléolo central (n). No citoplasma complexo de Golgi (CG), vesículas (V), 
vacúolos (seta vermelha), retículo endoplasmático (seta pequena) mitocôndrias $(\mathrm{m})$ e ribossomos livres (seta verde). Barra: $2 \mu \mathrm{m}$

Figura 17 - Eletromicrografia de monócito no rim cefálico. Observar a forma irregular da célula com projeções citoplasmáticas (seta larga branca), núcleo grande $(\mathrm{N})$ com reentrâncias e heterocromatina e eucromatina (seta branca). No citoplasma presença de complexo de Golgi (CG), grânulos $(G)$, vesículas (seta vermelha), mitocôndrias $(m)$ e vacúolos (v). Barra: $2 \mu \mathrm{m}$

Figura 18 - Eletromicrografia de plasmócito no rim cefálico (seta larga). Célula caracterizada pela grande quantidade de reticulo endoplasmático rugoso em seu citoplasma (seta vermelha). Núcleo grande central com heterocromática na periferia $(\mathrm{N})$, algumas mitocôndrias $(\mathrm{m})$, vacúolos $(\mathrm{V})$, vesículas (seta azul) e material eletro-denso (seta verde) disperso pelo seu citoplasma. Barra: $2 \mu \mathrm{m}$

Figura 19 - Fotomicrografia A: Parênquima do fígado constituído por hepatócitos (círculo pontilhado), artéria hepática $(A)$, um ducto biliar (seta) e um ramo da artéria (V). Barra: $50 \mu \mathrm{m}$ B: Veia central (V) associada a um ducto. Coloração HE. Barra: $50 \mu \mathrm{m}$ 82

Figura 20 - Fotomicrografia do parênquima do fígado. Observar um parênquima formado por hepatócitos em forma de cordões e entre eles um pequeno vaso sinusóide (setas finas). Células dendriticas ou endoteliais (seta larga) aparecem entrem os hepatócitos. No interior dos hepatócitos observar a presença de gotículas amarronzadas e espaços vazios. Aumento Coloração HE. Barra: $20 \mu \mathrm{m}$ 
Figura 21 - Eletromicrografia do hepatócito.. Esta célula apresentou um núcleo grande com cromatina condensada na periferia e dispersa pelo núcleo $(\mathrm{N})$. No citoplasma grânulos $(\mathrm{G})$, mitocôndrias $(m)$, complexo de Golgi $(\mathrm{cg})$ e reticulo endoplasmático rugoso (seta). Barra: $2 \mu \mathrm{m}$

Figura 22 - Eletromicrografia de estruturas do hepatócito. Observar a presença de um complexo de Golgi (seta larga) bem desenvolvido, mitocôndrias $(\mathrm{m})$ e vacúolos $(\mathrm{V})$ onde poderia estar contido gordura. Barra: $2 \mu \mathrm{m}$

Figura 23 - Fotomicrografia. A: timo constituído pelo Corpúsculo de Hassall (circulo pontilhado), vasos sangüíneos (seta) Barra: $50 \mu \mathrm{m}$ B: no tecido conjuntivo presença de vaso sangüíneo (V) e infiltrado mononuclear (circulo). Coloração Tricromo de Masson. Barra: 50 $\mu \mathrm{m}$

Figura 25 - Fotomicrografia de luz de parênquima tímico sem definição de zona cortical e medular. Parênquima constituído por hemácias (h), timócito (seta amarela), eosinófilo (seta branca) e células imaturas (ci). Coloração HE. Barra: $20 \mu \mathrm{m}$. 89

Figura 26 - Eletromicrografia de célula tronco do timo. Observar o formato irregular, com núcleo grande com cromatina heterogênea $(N)$, nucléolo excêntrico $(n)$ e disperso no citoplasma mitocôndrias, Complexo de Golgi e vacúolos. Barra: $2 \mu \mathrm{m}$ 90

Figura 27 - Eletromicrografia de eosinófilo encontrado no timo de Piaractus mesopotamicus. Célula com formato irregular, núcleo excêntrico e grânulos dispersos em seu citoplasma. Barra: $2 \mu \mathrm{m}$ 
Figura 28 - Eletromicrografia de trabécula (tr) encontrada no timo. Constituída por células achatadas com núcleo pequeno no ápice celular (seta), vaso sangüíneo $(\mathrm{V})$, no parênquima fibras colágeno $(F C)$, células reticulares $(C R)$, células limitantes (CL) e grânulos (G). Barra: 10 $\mu \mathrm{m}$

Figura 29 - Eletromicrografia de timócito. Célula com núcleo grande de formato irregular $(\mathrm{N})$, hetrorocromatico (estrela). Apresentando projeções na membrana citoplasmática (seta larga), vacúolos (V) e Complexo de Golgi (CG) no citoplasma. Barra: $2 \mu \mathrm{m}$.

Figura 30 - Eletromicrografia de célula limitante no timo. Observar a forma irregular da célula (CL) com extensões citoplasmáticas (seta larga). Seu núcleo irregular acompanha a forma da célula $(\mathrm{N})$. Barra: $2 \mu \mathrm{m}$

Figura 31 - Eletromicrografia de "nurse-cells". Observar vacúolos (V), vesículas com material flocular (seta larga) e pequeno complexo de Golgi (seta vermelha) dispersos no citoplasma. Barra: $2 \mu \mathrm{m}$ 95

Figura 32 - Fotomicrografia. A: baço constituído por polpa branca (PB) e polpa vermelha (PV). Barra: $50 \mu \mathrm{m}$ B: trabécula $(\mathrm{T})$ dividindo o parênquima, constituída por tecido conjuntivo (seta), artérias (A) e veias (V). Coloração HE. Barra: 50 $\mu$ m. 98

Figura 33 - Fotomicrografia de luz do parênquima do baço. Foram observados dispersos pelo parênquima vasos sanguineos (V), melano-macrófagos livres (seta branca), eosinófilos (seta amarela) e linfócitos (seta azul). Coloração HE. Barra: $20 \mu \mathrm{m}$ 
Figura 34 - Eletromicrografia de célula reticular do baço. Célula de formato irregular e pequenas projeções citoplasmáticas (seta azul), com núcleo grande heterocromático $(\mathrm{N})$. Observar no citoplasma mitocôndrias (m) e material eletrodenso (seta branca). Barra: $2 \mu \mathrm{m}$

Figura 35 - Eletromicrografia de esplenócito. Observar a forma arredondada da célula, núcleo com cromatina condensada na membrana $(\mathrm{N})$ e citoplasma granular $(\mathrm{G})$. Observar extensões celulares de células limitantes $(\mathrm{CL})$ conectandoas (seta). Barra: $2 \mu \mathrm{m}$

Figura 36 - Eletromicrografia de célula limitante no baço. Célula com forma irregular $(\mathrm{CL})$ e núcleo heterocromático acompanhando a forma da célula (seta). Observar que a célula envolve uma "nurse cells"' (CN). Barra: $2 \mu \mathrm{m}$ 102

Figura 37- Fotomicrografia das células sangüíneas encontradas no sangue periférico de Piaractus mesopotamicus. A: eosinófilos (eo), trombócitos ( $\mathrm{t}$ ), hemácia (seta) e linfócito (I). B: célula granulocítica especial (cge). C: célula imatura (ci) e neutrófilo (n). D: monócito (m). Coloração de Panótico rápido. Barra: $20 \mu \mathrm{m}$ 


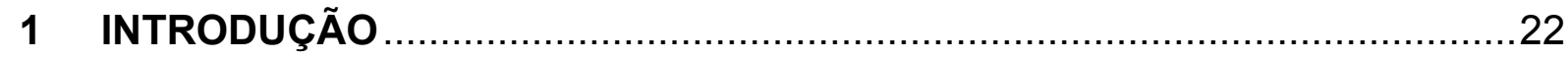

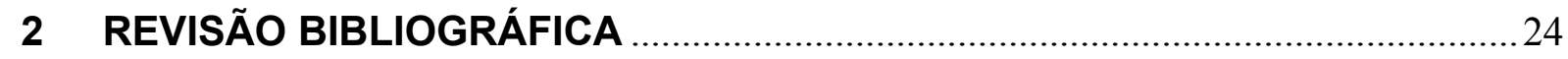

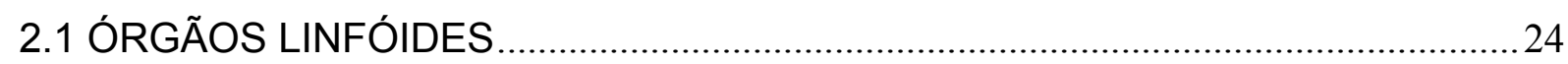

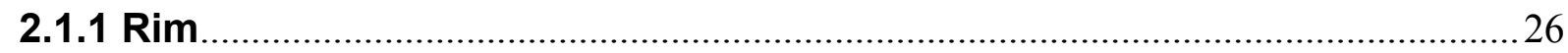

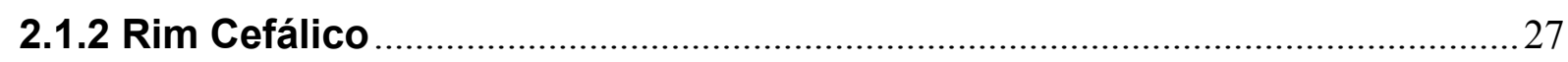

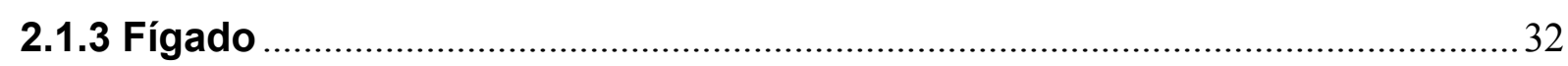

2.1.4 Timo

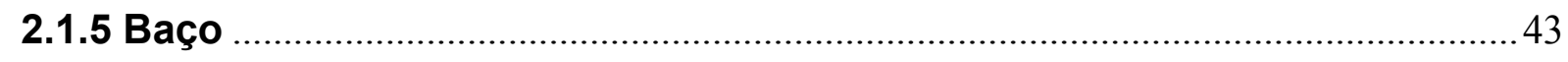

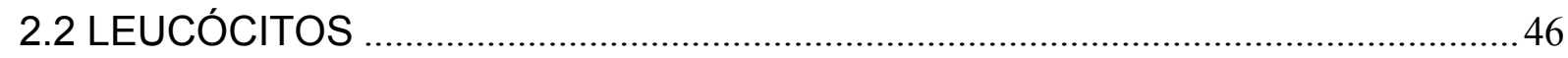

2.2.1 Monócitos-Macrófagos .................................................................................. 47

2.2.2 Melano-Macrófagos Centrais …………………........................................... 47

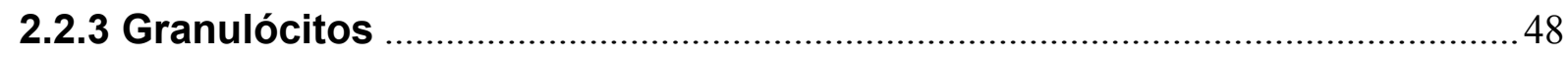

2.2.4 Linfócitos

2.2.5 Células Granulocíticas Especiais ……………….........................................4

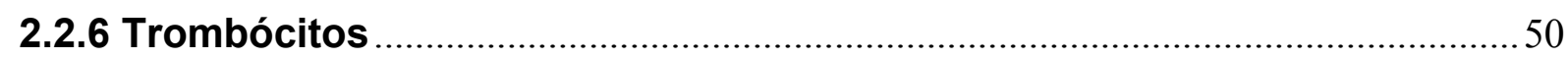

2.2.7 Eosinófilos 


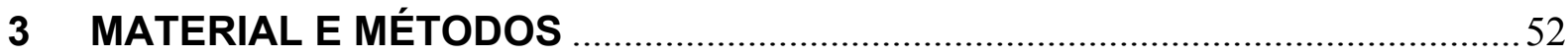

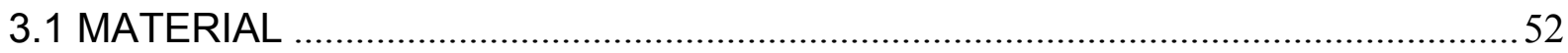

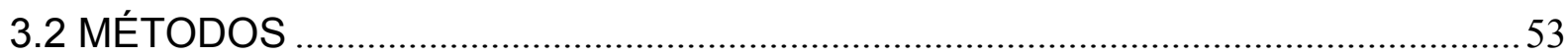

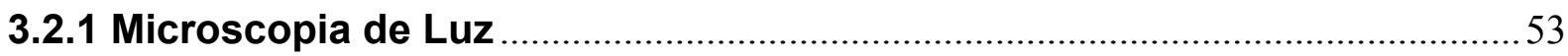

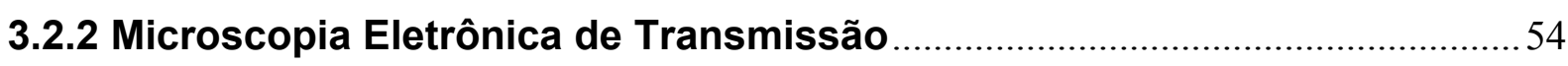

4 RESULTADOS

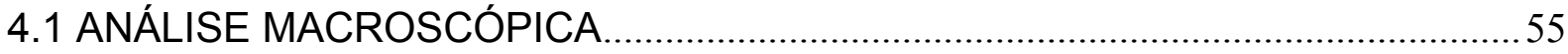

4.1.1 $\operatorname{Rim}$

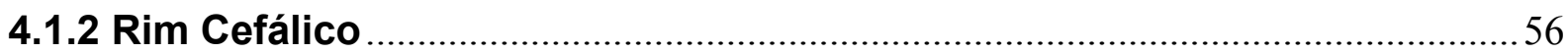

4.1.4 Timo

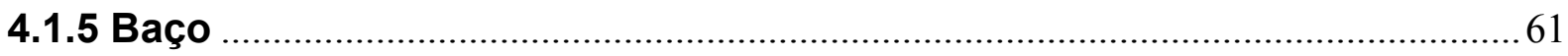

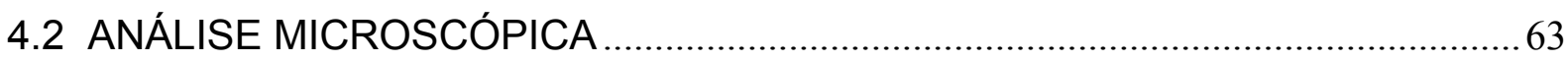

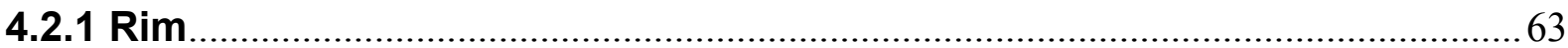

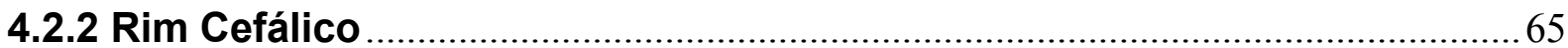

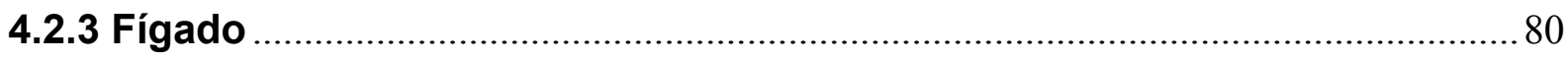

4.2.4 Timo 


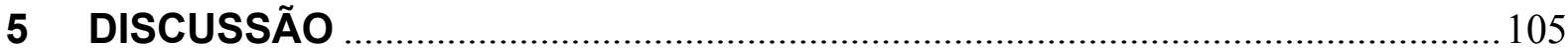

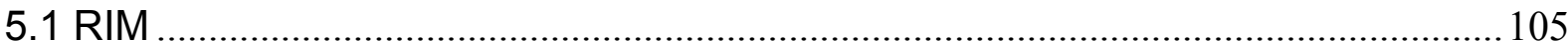

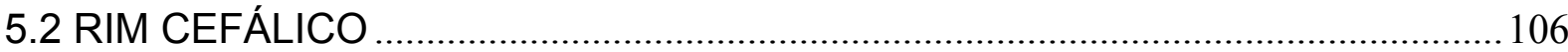

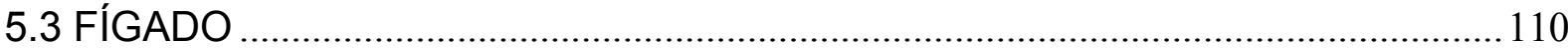

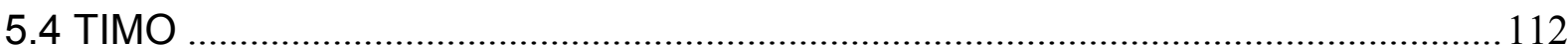

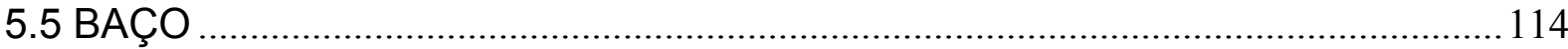

5.6 SANGUE

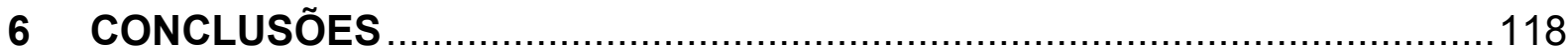

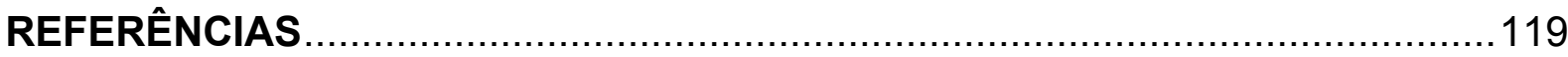




\section{INTRODUÇÃO}

O Brasil possui grande potencial hídrico e climático, possibilitando o cultivo de diversas espécies de peixes. Contudo, a piscicultura ainda apresenta resultados modestos de desenvolvimento devido aos processos de produção adotados e à falta de informações sobre as espécies nativas (BEERLI; LOGATO; FREITAS, 2004).

O pacu, Piaractus mesopotamicus (HOLMBERG, 1887), é um teleósteo da Família Characidae, a qual engloba a maior parte dos peixes de água doce do Brasil, com cerca de 400 espécies (BRITSKI, 1970; FERRAZ DE LIMA, 1993). É uma espécie endêmica da bacia dos rios Paraná-Paraguai, de grande importância econômica, sendo a mais cultivada da região neotropical (SEREVI, 2000). Entretanto, Petreri Jr. (1989) descreveu sua distribuição como sendo uma espécie originária do Rio Prata e do Pantanal do Mato Grosso, sendo morador habitual dos rios Paraná, Mogi-guaçu, Paraíba e baixo Tietê.

O pacu é um peixe de escamas, com corpo rombóide e achatado, possuindo uma coloração uniforme, variando do castanho ao cinza escura, com o ventre amarelado. Os dentes são do tipo molariforme (BRITSKI, 1970). Apresenta respiração branquial obrigatória, sobrevivendo tanto em ambiente natural quanto em viveiros de criação. Quando submetido à baixa tensão de oxigênio dissolvido, desenvolve a formação de uma expansão temporária do lábio inferior, vulgarmente chamada de beiço (FERRAZ DE LIMA et al., 1995).

No ambiente natural sua maturação sexual ocorre por volta dos quatro anos de idade, com cerca de $34 \mathrm{~cm}$ de comprimento total. Para sua comercialização seu tamanho ideal para captura é de $40 \mathrm{~cm}$ de comprimento (ALMEIDA, 2003).

Esta espécie é migratória, onívora, apresenta hábito alimentar especificamente frugívoro-onívoro, do tipo podador e de caráter oportunista. Tem como principais características, alta capacidade de aproveitamento de alimentos de origem vegetal, carne firme e com excelente sabor, resistente, de fácil crescimento, desova completa e de fácil adaptação para a produção em confinamento (CESTAROLLI et al., 1984; SILVA, 1985; CASTAGNOLLI; CYNIRO, 1986; CASTAGNOLLI, 1992). 
Das espécies nativas mantidas em estabelecimentos de pesca esportiva no Estado de São Paulo, os peixes "redondos" (pacu, tambaqui e seus híbridos) são os que ocorrem com maior freqüência (VENTURIERI, 2002). É uma espécie de importância econômica por ter uma grande aceitação pelo mercado consumidor. $\mathrm{O}$ pacu é uma das espécies brasileiras mais estudadas nas áreas da biologia, ecologia, nutrição e aqüicultura. Apesar disso, muitas dúvidas ainda persistem sobre as exigências nutricionais e fisiológicas desta espécie dada a grande diversidade de sistemas de cultivo, ambientes ocupados, ingredientes e aditivos para rações, manejo do cultivo e outros fatores que determinam diferentes respostas dos animais (ALMEIDA, 2003).

Apesar de já haver o aprimoramento das técnicas de reprodução, alimentação e manejo na piscicultura, muitos problemas ainda precisam ser resolvidos (BEERLI; LOGATO; FREITAS, 2004), principalmente em relação ao conhecimento do seu sistema imune para se garantir a qualidade da higidez do animal e, desta forma, ter uma produção satisfatória e saudável dos peixes nestes sistemas de cultivo.

Considerando a grande diversidade de espécies de peixes teleósteos e a conseqüente variação morfofisiológica, o sistema linfóide permite uma grande área de estudos. Apesar de, nas últimas décadas, vários estudos terem sido realizados, pouco se conhece, havendo pouca informação sobre estruturas e função dos órgãos linfo-hematopoiéticos de teleósteos (ROCHA et al., 2001).

Conhecendo a importância econômica do pacu (Piaractus mesopotamicus) e considerando a pouca informação sobre a morfologia dos órgãos do seu sistema imune, este trabalho objetivou o estudo histomorfológico e a análise de seus componentes celulares pela microscopia de luz e eletrônica de transmissão do rim cefálico, fígado, timo e baço, visando o melhor entendimento da funcionabilidade e produção celular dos mesmos. 


\section{REVISÃO BIBLIOGRÁFICA}

Esta revisão procura apresentar sucintamente o estudo da histomorfologia dos órgãos linfóides de peixes e suas características ultraestruturais.

\section{1 ÓRGÃOS LINFÓIDES}

Em mamíferos o sistema de defesa é constituído pelo Sistema Linfático e o Vascular, formando o Sistema hematolinfático, o qual é constituído pelo baço, timo, linfonodos e nódulos linfáticos (BANKS, 1992).

Tizard (2002) separa os órgãos do Sistema Imune de vertebrados maiores em dois grupos: órgãos linfóides primários, constituídos pelo timo, pele, placas de Peyer, glândulas linfoepiteliais, medula óssea e bursa de Fabricius em aves. Têm por função regular a produção e a diferenciação dos linfócitos, de modo que os linfócitos maduros, por sua vez, se encaixem em duas populações principais, as células T e B, dependendo do órgão linfóide primário de sua maturação. Os órgãos linfóides secundários são constituídos pelos linfonodos, nódulos hemolinfáticos e baço, e são responsáveis pela resposta e estimulação antigênica produzindo células de defesa e são ricos em macrófagos, células dendítricas e linfócitos $T$ e $B$, os quais medeiam as respostas imunes.

De acordo com Zapata, Chibá e Varas (1996), em peixes modernos, incluindo condrictes e osteictes, o sistema linfo-hematopoiético compõe-se por timo, baço e um fígado em desenvolvimento, que apresentam agregados linfóides, além de um grande número de diferentes órgãos que vão, desde uma meninge primitiva até o rim, contendo tecido linfo-hematopoiético, condição típica de vertebrados que possuem pouca medula óssea. Esses três autores relataram também que os peixes primitivos não possuem medula óssea linfo-hematopoiética, sendo a formação de células sanguíneas provenientes de órgãos distintos, cujas estruturas e funções são semelhantes às da medula óssea de vertebrados maiores. 
Em teleósteos de água doce os órgãos linfóides são constituídos pelo timo, rim (pro- e mesonefron) e baço. O timo é o primeiro órgão a se desenvolver e o rim contém progenitores hematopoiéticos não linfóides. Nos teleósteos marinhos ocorre o inverso, onde o maior órgão linfóide é o rim, depois o baço e finalmente o timo, ressaltando-se que o baço da larva teria uma função mais eritropoiética do que linfopoiética (ZAPATA et al., 2006).

Segundo Fishelson (2006) os teleósteos da Família Apogonidae, possuem timo, baço, rim cefálico e fígado formando o sistema linfo-hematopoiético principal.

Para Stoskopf (1993) os peixes são desprovidos de medula óssea, fonte de células mielóides de anuros e vertebrados maiores. Não apresentam linfonodos e o tecido linfóide e mielóide estão associados ao rim em teleósteos e esturjões, e ao fígado em elasmobrânquios e hagfish.

Segundo Chilmonczyk (1984) e Fange e Pulsford (1985) o timo nos peixes representa o mais primitivo dos tecidos linfóides. Os linfócitos são a população celular predominante, entretanto, não estão organizados num córtex distinto, como ocorre na medula de mamíferos.

Os órgãos linfóides são constituídos principalmente por linfócitos, monócitos, trombócitos, granulócitos e eritrócitos. A intensidade das atividades hematopoiéticas dos órgãos linfóides difere entre as diferentes espécies de peixes teleósteos (TAVARES-DIAS; MORAES, 2004). Além disso, existe ainda uma séria de tipos celulares descritos de diferentes formas por diferentes autores que também fariam parte dos órgãos do sistema imune e que se diferenciam entre as varias espécies de peixes teleósteos (BIELEK, 1981; ZAPATA, 1983; ZUASTI; FERRER, 1988; MESEGUER; ESTEBAN; AGULLEIRO, 1991; ROCHA et al., 2001).

O tecido hematopoiético está associado ao fígado em lampréias, tubarões e raias. A válvula espiral dos cartilaginosos é rica em tecido mielóide, que também está associado ao órgão epigonal e ao órgão de Leydig (STOSKOPF, 1993), sendo também o baço um importante órgão linfomielóide nestas classes, produtor de eritrócitos, linfócitos e trombócitos (WALSH; LUER, 1998).

Nos peixes teleósteos o tecido hematopoiético localiza-se no interstício renal, estroma esplênico, nos espaços periportais hepáticos, submucosas intestinais, no peritônio e no timo (QUENTEL; OBACH, 1992). 
O processo de renovação das células do sistema imune é realizado através da hematopoiese, onde ocorre à diferenciação de células tronco multipotentes em células progenitoras na medula óssea (BARREDA; NEUMANN; BELOSEVIC, 2000).

Em mamíferos a hematopoiese é desencadeada em resposta a fatores estimulantes da colônia exógena de macrófagos e outros fatores de crescimento (STAFFORD et al., 2001), enquanto nos peixes a produção de macrófagos se deve a fatores de crescimento endógenos, responsáveis por regularem sua diferenciação e proliferação, eventos pouco conhecidos em vertebrados menores como os teleósteos (NEUMANN; BARREDA; BELOSEVIC, 1998).

\subsubsection{Rim}

O rim em vertebrados maiores é uma glândula tubular composta, formada por túbulos renais, apresentando em algumas espécies apenas um lobo, embora, em outras, a lobação possa persistir ou fundir-se secundariamente. Este lobo é formado por componentes medulares e corticais exercendo um papel central na criação e manutenção de um ambiente interno, no qual as células constituintes são capazes de prosperar e, em contrapartida, funcionar como um órgão endócrino, secretando renina, fator eritropoiético renal e metabólitos ativos da vitamina D. O rim e as vias urinárias filtram o sangue, removendo os produtos residuais, recuperando os metabólicos úteis, armazenando os resíduos líquidos e transportando os produtos residuais para o exterior (BANKS, 1992).

Ellis e Souza (1974) e Zapata $(1979,1981)$ e Hibiya (1982) relataram que o rim de teleósteos apresenta função excretora e é um importante órgão linfóide composto de dois segmentos distintos: um anterior cefálico, rim cefálico ou pronefron e o médio ou posterior, tronco do rim ou protonefron, embora estruturalmente similares. Essas regiões mostram capacidade hematopoiética, sendo maior no rim cefálico, cuja função renal desapareceu.

A função excretora do rim de peixes é observada, primeiramente, no rim caudal. O rim cefálico contém uma variedade de tecidos que não têm função no sistema urinário (STOSKOPF, 1993). 
Segundo alguns autores, nos peixes, o rim cefálico ou protonéfron é um órgão muito complexo, que realiza diversas funções e é formado por uma variedade de células e tecido epitelial (MESSEGUER et al., 1991; ESTEBAN; MESSEGUER, 1994; FISHELSON, 1996; BECKER; FISHELSON; AMSELGRUBER, 2001).

De acordo com Fergunson (1995) o rim de teleósteos é um órgão fundido que se encontra localizado retroperitonealmente na região dorsal da cavidade celomática, ventralmente à coluna vertebral, frequentemente aderido nestes processos.

Histologicamente, o rim de peixes é extremamente variável. O glomérulo é estruturalmente similar ao glomérulo de mamíferos, composto por um corpúsculo renal completo, com cápsula de Bowman, arteríolas aferentes e células justaglomerulares. O tamanho dos glomérulos é altamente variável entre as espécies: os peixes de água doce têm glomérulos maiores e mais numerosos que peixes marinhos, e algumas espécies marinhas apresentam rim aglomerular (STOSKOPF, 1993). Fergunson (1995) descreveu o rim contendo nefrons com variadas quantidades de tecido hematopoiético e linfóide no interstício e Hibiya (1982) observou que este era constituído por muitos nefrons e por tecido linfóide e o rim cefálico composto por tecido linfóide.

Ainda segundo Stoskopf (1993), os peixes não apresentam alça de Henle e o túbulo contorcido distal ocorre apenas no rim de peixes de água doce. A diferença entre o túbulo contorcido distal do túbulo contorcido proximal é a presença de células epiteliais que são menos eosinofílicas e sem borda em escova.

\subsubsection{Rim cefálico}

O rim cefálico representa o principal órgão formador de células sangüíneas em teleósteos (ZUASTI; FERRER, 1988; BIELEK, 1981).

Segundo Powell (2000) o rim cefálico em peixes teleósteos, primariamente é formado por tecido hematopoiético, contendo células hematopoiéticas e fagocíticas. $\mathrm{Na}$ sua porção posterior contém túbulos e glomérulos do sistema excretor, parecendo ser um órgão multifuncional, porém não possuindo função excretora e osmorregulatória. 
De acordo com Fergunson (1995), este órgão apresenta tecido hematopoiético e linfóide e elementos endócrinos, células de cromatina e tecido interrenal podem ser localizados ao redor de vasos sanguíneos maiores, relativo à medula e córtex na adrenal de mamíferos.

Foi observado por Rocha et al. (2000) que o rim cefálico apresenta um parênquima composto por uma glândula interrenal formada por grupos, celulares; tecido cromafin formado por pequenos grupos de células cromafin e melanomacrófagos centrais adicionados ao tecido linfóide e hematopoiético.

No rim cefálico cada linhagem de células hematopoiéticas parece ser diferenciada a partir de células progenitoras (AL-ADHAMI; KUNS, 1976) com uma importante capacidade linfo e plasma-citopoiética (SMITH et al., 1967). A atividade hematopoiética no rim cefálico de teleósteos varia entre uma espécie e outra, podendo ser considerado um órgão linfopoiético ou exclusivamente eritropoiético, entretanto este órgão pode, em algumas espécies, ter uma função exclusivamente linfo ou eritropoiética, enquanto em outras pode apresentar uma função hematopoiética plena (ELLIS et al., 1976; ZAPATA, 1980).

Fishelson (1996) descreveu que durante a ontogênese o rim cefálico, inicialmente funciona como órgão hematopoiético parenquimatoso, função que mais tarde desaparece e o órgão passa a ter predominantemente funções de excreção e endócrinas.

Rocha et al. (2001) descreveu o rim cefálico de Brycon cephalus composto por lobos bilaterais fundidos, localizados anteriormente a bexiga natatória e ventrolateralmente a coluna espinhal. Apresenta a superfície ventral recoberta por peritônio parietal e o lobo direito ligeiramente maior que o lobo esquerdo.

Conforme Hibiya (1982), no rim cefálico o tecido linfóide e o intertubular, tecidos hematopoiéticos de teleósteos, são compostos de tecido reticular, células reticulares e muitos capilares, podendo ser encontrados no interior destes tecidos, mastócitos e células maduras do sangue, observando-se ainda mitoses que indicariam o processo de formação de células sanguíneas.

Já para Stoskopf (1993) o tecido linfóide é completamente proeminente no rim cefálico, que é altamente vascularizado, contendo células maduras do sangue no interior de seus capilares como as células hematopoiéticas. A atividade mitótica deste tecido apresenta-se normalmente elevada. 
Histologicamente o rim cefálico é recoberto por uma cápsula de tecido conjuntivo fibroso denso (ROCHA et al., 2001), constituído por uma rede reticular de células estromais, macrófagos livres e elementos linfóides, além de células granulopoiéticas, trombopoiéticas e eritropoiéticas (MESEGUER; ESTEBAN; AGULLEIRO, 1991).

Tecido linfóide e hematopoiético formados por uma variedade de tipos celulares, glândula interrenal, tecido cromafin, grupos de melano macrófagos centrais e livres, células vermelhas em diferentes estágios de maturação adicionados ao tecido hematopoiético e linfóide foram observados constituindo o parênquima do rim cefálico de Sea bass (MESEGUER; ESTEBAN; AGULLEIRO, 1991), Clarias gariepinus (VERMEULEN et al., 1995), Sparus auratus (ZUASTI; FERRER, 1988, 1989) e Hoplias malabaricus, (MELA et al., 2006). Entretanto, foi relatado por Vermeulen et al. (1995) em Clarias gariepinus, que o tecido interrenal desta espécie está localizado em outros órgãos e em Hoplias malabaricus, a maior parte das células que constituem o rim cefálico são de leucócitos e células vermelhas em diferentes estágios de maturação (MELA et al., 2006).

Para Zuasti e Ferrer (1988) o rim consiste de ambos os tecidos, excretor e hematopoiético, sendo que o tecido hematopoiético é encontrado principalmente na porção anterior do rim (rim cefálico) e todos os tipos celulares encontrados no rim cefálico são originadas de uma única célula tronco.

Ultraestruturalmente as células encontradas no rim cefálico de algumas espécies de peixes teleósteos estudados como Brycon cephalus (ROCHA et al, 2001), Dicentrarchus labrax (ESTEBAN et al., 1989; MESEGUER et al., 1990), Sparus auratus (ZUASTI; FERRER, 1988,1989) entre outras, as mais comumente encontradas e descritas foram macrófagos, melano-macrófagos, células estromais, células reticulares, linfócitos e células granulopoiéticas. Entre estas descrições, diferentes autores relataram diferenças estruturais relativas ao tamanho do núcleo, granulação e forma e os colocaram em séries dentro de grupos.

Os melano-macrófagos podem ser encontrados livres ou agrupados como melano-macrófagos centrais. Estas células continham grânulos ou hemossiderina e estavam frequentemente associadas aos lisossomos (MESEGUER; ESTEBAN; AGULLEIRO, 1991). São células pigmentadas com material heterogêneo ou granular, com coloração que vai do amarelo ao marrom escuro. Quando há o aumento no número destas células no rim cefálico, indica o aumento da atividade 
fagocítica no órgão (RABITTO et al., 2005; MELA et al., 2006). O tamanho, número e conteúdo são altamente variáveis, estando este fato relacionado à espécie, idade e status de saúde (AGIUS, 1980).

Os macrófagos são células grandes de formato irregular, com um núcleo excêntrico de margem irregular, ocasionalmente apresentam nucléolos. Em seu citoplasma encontram-se dispersos lisossomos de variados tamanhos, mitocôndrias com cristas escassas, vesículas, um complexo de Golgi pequeno, ribossomos e reticulo endoplasmático rugoso e pode haver a presença de debris (ELLIS, 1976; FERGUNSON, 1976; BIELEK, 1980; HAWKINS et al., 1981).

Entre as células estromais estão inclusas as células sinusóides, que formam uma parede entre o tecido hematopoiético e o sangue. Apresentam um formato achatado, estando conectadas por interdigitações celulares e junções intercelulares. O seu citoplasma apresenta pequenas vesículas, microfilamentos, microtúbulos, um pequeno complexo de Golgi, ribossomos livres, lisossomos, peroxissomos e glicogênio (ZAPATA, 1983; FÄNGE; NILSSON, 1985; CROCKER; MORRIS; GORDON, 1988; MESEGUER; ESTEBAN; AGULLEIRO, 1991).

Células reticulares formam uma rede de tecido hematopoiético. São células grandes com processos de filamentos citoplasmáticos e se ligam por desmossomos. Apresentam um núcleo redondo heterocromático, algumas mitocôndrias, ribossomos livres, complexo de Golgi e numerosas vesículas arredondadas de variados tamanhos, algumas contendo material moderadamente denso, homogêneo ou granular. Estas células também foram classificadas como células reticulares tipo macrófagos. Seus processos celulares circundavam eritroblastos ou outro tipo de célula hematopoiética. Apresentavam um núcleo lobado heterocromático e numerosas vesículas com material heterogêneo (ZAPATA, 1983; CROCKER; MORRIS; GORDON, 1988; MESEGUER; ESTEBAN; AGULLEIRO, 1991).

Linfócitos foram observados em todas as espécies estudadas, livres ou em pequenos agrupamentos, apresentando tamanho grande e pequeno. Sua constituição era similar em ambos os tamanhos e mostraram uma forma arredondada com margem irregular, um núcleo grande oval ou arredondado e central com cromatina condensada e um nucléolo excêntrico. Disperso no seu citoplasma mitocôndrias, ocasionalmente cisternas de reticulo endoplasmático rugoso, complexo de Golgi e ribossomos livres. A superfície da célula em alguns 
casos apresentava microvilos curtos (CHILMONCZYK, 1978; MILLER et al., 1985; ZUASTI; FERRER, 1989).

Células granulopoiéticas segundo Zuasti (1988) consistem de séries de promielócitos, mielócitos, metamielócitos e granulócitos maduros. Os promielócitos são células arredondadas edentadas, apresentam um núcleo pequeno heterocromático. No seu citoplasma há presença de grânulos, ribossomos, cisternas de reticulo endoplasmático granular e algumas mitocôndrias. Os mielócitos são células que apresentam um núcleo excêntrico heterocromático, no seu citoplasma pequenas vesículas, cisternas de reticulo endoplasmático e citoplasmático e grânulos eletro-densos. Em Dicentrarchus labrax apresentavam um núcleo pregueado com heterocromatina abundante e no citoplasma, cisternas de reticulo endoplasmático rugoso e algumas mitocôndrias estavam presentes (MESEGUER; ESTEBAN; AGULLEIRO, 1991). Os metamielócitos são células irregulares com núcleo excêntrico e pouca heterocromatina densa no núcleo, podendo se apresentar profundamente pregueado. O citoplasma mostra numerosos grânulos, homogeneamente eletro-densos circundado por uma membrana, algumas cisternas de reticulo endoplasmático liso, ribossomos livres e complexo de Golgi justanuclear (ZAPATA, 1979; ZUASTI, 1988; MESEGUER; ESTEBAN; AGULLEIRO, 1991). Os granulócitos maduros são similares aos metamielócitos, exceto por possuir um grande número de grânulos no citoplasma (ZUASTI, 1988). Esta célula mostrou um delineado irregular, com núcleo lobado excêntrico com heterocromatina na periferia. Em seu citoplasma estavam presentes ribossomos livres, pequenas mitocôndrias arredondadas, um complexo de Golgi bem desenvolvido e alguns grânulos pequenos de glicogênio (ELLIS, 1977; BIELEK, 1981; MESEGUER; ESTEBAN; AGULLEIRO, 1991).

Plasmócitos também formam observados e descritos como células arredondadas ou ovais, com núcleo grande central ou excêntrico com blocos de heterocromatina periféricos. A característica citoplasmática mais aparente desta célula são as numerosas cisternas de retículo endoplasmático rugoso. Ribossomos, mitocôndrias e numerosos grânulos de tamanhos e densidades diferentes estavam relacionados a um complexo de Golgi bem desenvolvido. Estas células também foram classificadas como plasmócitos maduros e sua principal característica foi a presença de numerosas cisternas de reticulo endoplasmático rugoso dilatados 
preenchidos por um material granular (PULSFORD; FANGE; MORROW, 1982; SAVAGE, 1983; ZUASTI; FERRER, 1989; ROCHA et al., 2001)

Há muita discussão e controvérsias a respeito de classificação e descrição das células do rim cefálico. Diferenças estruturais e ultraestruturais descritas para diferentes células em diferentes espécies de peixes podem ter relação apenas com a sazonalidade, maturidade sexual, idade, status de saúde ou mesmo adaptabilidade ambiental como sugerido por vários autores. Não tendo essas células uma função ou origem diferenciada.

\subsubsection{Fígado}

O fígado de mamíferos é a maior glândula isolada do corpo desempenhando diversas funções metabólicas. Essas funções são realizadas por dois tipos celulares: os hepatócitos e as células de von Kupffer (BANKS, 1992).

Os hepatócitos têm alto potencial mitótico e suas funções são de síntese, secreção, armazenamento, biotransformação e metabolismo. As células de von Kupffer são células do sistema macrofágico, revestem as regiões dos sinusoídes hepáticos, estando a atividade fagocitária do fígado ligada a função destas células (BANKS, 1992).

Segundo Takashi (1982) o fígado é uma das glândulas digestivas que se desenvolve de um brotamento do saco embrionário invaginando-se do arquêntero. É composto por células parênquimais hepáticas e arranjos de fibras cuja função é suportar a estrutura do órgão.

Em peixes, o fígado é um órgão compacto localizado ventralmente na cavidade celomática. Seu tamanho, forma e volume estão adaptados ao espaço utilizado pelos outros órgãos viscerais e varia muito entre as espécies. Apresenta uma coloração vermelho-pardo amarronzado (BRUSLÉ; ANADON, 1996), ou avermelhado (OSTRANDER, 2000), ocasionado pela densa vascularização, tendendo para o amarelo, quando o estoque de gordura é alto. Em muitas espécies de teleósteos o fígado é dividido em três lobos, entretanto, em alguns casos nenhuma lobação é reconhecida (BRUSLÉ; ANADON, 1996). Apresenta uma 
superfície lisa recoberta por membrana serosa e alguns tecidos conjuntivos desta cápsula se estendem pelo parênquima (OSTRANDER, 2000; FISHELSON, 2006).

Segundo Fergunson (1995) o fígado, em algumas espécies de peixes, é um órgão separado na porção anterior da cavidade celomática, enquanto em outras é dividido em lobos que se interligam com o intestino, podendo ter o comprimento da cavidade abdominal.

De acordo com Vincentine et al. (2005) o fígado de tilápia do Nilo (Oreochromis niloticus) é um órgão largo com apenas dois lobos. O lobo esquerdo é maior e se estende através de quase toda cavidade corpórea. Na face visceral observa-se a impressão do intestino. A vesícula biliar é bem desenvolvida e tem um formato arredondado.

Estruturas e função do fígado em teleósteos não apresentam grandes diferenças em comparação ao fígado de vertebrados maiores, estando as maiores funções do fígado relacionadas ao controle da homeostasia da glicose realizado pelas brânquias e ramos dos nervos simpáticos e parassimpáticos, assim como na detoxificação de substâncias estranhas e produção de glucagon e insulina (FISHELSON, 2006). Alguns estudos relataram alterações no fígado causadas por organoclorados e outros xenobióticos, existindo a possibilidade de usar estas alterações como bioindicadores de poluição ambiental (HINTON; LAUREN, 1980; FREDELLO et al., 2001).

De acordo com Fergunson (1995) o fígado também realiza funções metabólicas similares à dos mamíferos e, apesar de contradições nas informações relatadas, teleósteos possuem drogas metabolizando enzimas nas fases de ativação, inativação de grupos reativos e conjugação. Considerando o crescente número de xenobióticos ambientais, é de grande importância o rápido e eficiente caminho destas combinações pelo intestino, brânquias e pele destes animais para a adaptabilidade e sucesso do grupo.

Células fagocíticas mononucleares encontradas nos sinusoídes do fígado são conhecidas como células de Kupffer. Essas células fagocíticas, atacam bactérias e vírus no sangue (KENDALL; HAWKINS, 1975). Se a função das células Kupffer em peixes for similar a dos fígados de mamíferos, então essas células são capazes de apresentar antígenos para o linfócito T (ROITT; ROSTOFF; MALE, 1993). 
Segundo Powell (2000) o fígado em peixes também é responsável pela produção de proteínas serosas e de linfócitos adjacentes durante uma infecção, atuando como sistema de defesa.

A histologia é essencialmente similar à dos mamíferos, embora sua lobação seja menos distinta e menos organizada. A típica tríade da veia porta é bem óbvia como em mamíferos (FERGUNSON, 1995).

Em certas espécies de peixes o tecido pancreático exócrino pode ser observado circundando a veia porta.

Segundo Akiyoshi e Inoue (2004) um grande número de estudos morfológicos de células hepáticas, hepatócitos, células endoteliais, células de Kupffer, células de ductos biliares no nódulo hepático e no sistema biliar têm revelado detalhes de sua relação e estabelecido estruturas e funções do fígado. Eles estudaram o fígado de 200 espécies de peixes teleósteos, estas espécies pertenciam a três ordens e doze famílias e relataram que em quase todos os peixes as unidades estruturais conhecidas como lóbulos hepáticos estavam ausentes. Na maioria das espécies o fígado era composto principalmente de um campo compacto contínuo de hepatócitos, com ilhas de tecido conjuntivo próximo a ductos biliares e vasos arteriais. Em algumas poucas espécies, os lóbulos hepáticos foram demarcados por tecido conjuntivo contendo ductos biliares, veia porta e artérias, similares ao trato portal em mamíferos.

As estruturas hepáticas dos peixes foram classificadas por Akiyoshi e Inoue (2004) em três tipos diferentes: em forma de cordões; em forma tubular e forma sólida. No tipo cordão a maioria dos hepatócitos estavam alinhados em camadas simples. Os sinusóides hepáticos eram dilatados e estavam diretamente ligados por vasos perilobulares. Os hepatócitos tinham formato poliédrico com núcleo arredondado. Na forma tubular a maioria dos hepatócitos alinhavam-se em dupla camada e os capilares sinusóides tinham formato irregular e estreito, surgindo entre o interstício e as camadas hepáticas. Três a quatro hepatócitos circundavam um capilar sinusoidal. Os hepatócitos eram poliédricos ou arredondados com núcleo redondo. Na forma sólida a maior parte dos hepatócitos se alinhavam em camadas múltiplas. Os sinusóides hepáticos eram estreitos e os capilares pequenos e tortuosos. Neste caso os hepatócitos eram redondos com núcleos pequenos e arredondados. Em todos os casos o citoplasma dos hepatócitos estava preenchido com gotículas de gordura. 
Para Hinton, Snipes e Kendall (1972) e Hinton e Pool (1976) o parênquima hepático de teleósteos é constituído por duas linhas celulares circundadas por sinusoídes. Entre os sinusoídes os hepatócitos são arranjados em cordões que se estendem entre a zona portal e centrais.

Bruslé e Anadon (1996) descreveram o parênquima hepático do teleósteo Micropogon undulatus como sendo muito homogêneo constituído por hepatócitos poligonais, muitas vezes fracamente basofílicos se comparados aos de mamíferos. Apresenta núcleo esférico com um único nucléolo central. Ao redor dos sinusóides os hepatócitos estavam arranjados como cordas, usualmente com duas células grandes, mas bifurcações e anastomoses destas cordas podiam resultar em quatro ou mais camadas de células, circundados por sinusóides. As tríades eram constituídas por uma ramificação da veia portal, uma artéria hepática e um ducto biliar bem distintos. Este mesmo arranjo foi observado em Oreochromis niloticus (VINCENTINE et al., 2005), estando o ducto biliar localizado próximo a veia porta e era constituído por um epitélio cúbico simples. Uma camada concentrada de colágeno e fibras musculares foi observada sob o epitélio.

Mela et al. (2006), estudando o efeito da contaminação por mercúrio em Hoplias malabaricus, descreveu o fígado de indivíduos do grupo controle constituído por hepatócitos organizados em cordões, geralmente apresentando duas células grandes entre dois sinusóides contínuos.

Elementos vasculares, veias, artérias e ducto biliar foram observados espalhados dentro do parênquima do fígado de Salmo trutta por Rocha, Monteiro e Pereira (1994) tendo sido descrita a presença de alguns vasos sanguíneos que não estavam associados a nenhum outro vaso e outros estavam associados a uma ou duas arteríolas. Observou-se também uma associação de três elementos, uma veia, uma ou duas arteríolas e o ducto biliar. Os ductos biliares estavam tanto isolados como em grupos de duas ou três unidades. Frequentemente, uma arteríola estava associada aos ductos, arteríolas isoladas foram raramente observadas. Células Ito foram ocasionalmente observadas no espaço Disse (ROCHA; MONTEIRO; PEREIRA, 1994). Estas células foram encontradas em conexão com vasos venosos de pequeno calibre por Rocha, Monteiro e Pereira (1997) e veias centrais foram observadas dispersas no parênquima (ROCHA; MONTEIRO; PEREIRA, 1994).

Para Hacking, Budd e Hodson (1977) o sistema sinusoidal do fígado de truta arco-iris era morfologicamente similar a de outros animais, exceto pela ausência 
evidente de células de Kupffer. As células associadas com os sinusóides eram células de armazenamento de gordura e células endoteliais. Estas células tinham algumas extensões citoplasmáticas curtas no lúmen sinusoidal.

Fujita, Tamaru e Miygawa (1980) observaram a ocorrência de numerosos desmossomos entre as células Ito de alguns teleósteos, sugerindo que essas células têm a função de suporte nestes animais, juntamente com a vitamina $A$, armazenando gordura.

No fígado de bacalhau uma característica do sistema de suporte de células de Ito e seus processos citoplasmáticos, constituem redes tridimensionais que formam o órgão (FUJITA, 1985), sendo estas células o principal componente celular no espaço perisinoidal deste órgão (FUJITA et al., 1986),

Arellano, Storch e Sarasquete (1999) relataram que em fígado de Solea senegalenses o sistema porta, ducto biliar e arteríolas hepáticas não estão agrupados juntos na tríade hepática e não apresentavam lóbulos hepáticos.

Rocha, Monteiro e Pereira $(1994,1997)$ descreveram em truta marrom (Salmo trutta) o fígado composto, principalmente por um campo compacto de hepatócitos com sinusóides e ilhas de tecido conjuntivo que envolvem ductos biliares, vasos arteriais e venosos. Os hepatócitos estão organizados radialmente em túbulos sinuosos e ramificados, aparecendo como placas com dois ou mais hepatócitos. Em algumas áreas do tecido conjuntivo foi observada a presença de células fortemente pigmentadas coradas em grupos, os melano-macrófagos centrais.

Bruslé e Anadon (1996) relataram que veias hepáticas classicamente localizadas no centro dos lóbulos hepáticos, também chamadas veias centro lobular, são encontrados dispersas em todas as partes do parênquima hepático, estando ausente os lóbulos hepáticos. Eles também relataram a ocorrência de melanomacrófago centrais no parênquima hepático de Lutjanus bohar e Plectropomus leopardus. O tamanho, número e conteúdo destas células são altamente variáveis, dependendo da espécie, idade e estado de saúde do animal. Estão normalmente localizados próximos as arteríolas hepáticas, veias portais ou ductos biliares. Segundo estes autores eles concentram materiais heterogêneos como lipofucsina, melanina e hemosiderina, que podem ter um papel na neutralização de radicais livres potencialmente tóxicos e produção de cátions durante peroxidação de lipídeos insaturados. 
Segundo Mela et al. (2006) os melano-macrófagos são células pigmentadas com material heterogêneo ou granular de cor amarelo ao marrom escuro e podem aparecer isoladas ou arranjadas em grupos formando os melano-macrófagos centrais.

Entre os hepatócitos adjacentes ao espaço de Disse foram observados em Salmo trutta, macrófagos com citoplasma rico em pequenas vesículas e fagolisossomos, porém pobres em organelas. Células alongadas e pleomorfas no espaço perisinusoidal emitiam projeções citoplasmáticas finas, apresentavam poucos microtúbulos, alguns retículos endoplasmáticos rugosos e gotas de lipídios. Estas células foram consideradas como células de lto ou células estreladas (ROCHA; MONTEIRO; PEREIRA, 1997). Em Solea senegalenses foi observado que os hepatócitos apresentavam muitas gotas lipídicas durante a época de reprodução (ARELLANO; STORCH; SARASQUETE, 1999).

Ultraestruturalmente os hepatócitos de peixes apresentam um núcleo arredondado, localizado centralmente. A cromatina é granular com heterocromatina condensada localizada na periferia do núcleo. O nucléolo é mais homogêneo e se apresenta muito eletro-denso. O retículo endoplasmático rugoso muitas vezes está disposto paralelamente ao núcleo. As mitocôndrias são arredondas ou alongadas e estão associadas ao reticulo endoplasmático rugoso. Vacúolos citoplasmáticos de diferentes tamanhos estão distribuídos no citoplasma (VINCENTINE et al., 2005).

Rocha, Monteiro e Pereira (1997) descreveram hepatócitos com um núcleo simples e um citoplasma rico em retículo endoplasmático rugoso e glicogênio, sendo o reticulo endoplasmático liso escasso (ROCHA; MONTEIRO; PEREIRA, 1994). O revestimento dos sinusóides possuíam projeções ramificadas em formato de dedos, estendendo-se através do espaço de Disse. Células do endotélio sinusoidal apresentavam um típico aspecto alongado achatado freqüentemente fenestrado (ROCHA; MONTEIRO; PEREIRA, 1997).

Hinton e Pool (1976) observaram que hepatócitos de Ictalurus punctatus apresentavam acima da zona lateral microvilos que se estendiam para dentro das passagens biliares. Estas células apresentavam organelas múltiplas, incluindo mitocôndrias e retículo endoplasmático rugoso organizados ao redor do núcleo, assim como ao longo e próximo a membrana citoplasmática, formando uma fina camada eletro-densa limitante entre os hepatócitos. Corpos lipídicos também eram esporadicamente visíveis no citoplasma dos hepatócitos. Seus núcleos 
apresentavam uma abundante eucromatina e pouca heterocromatina condensada na periferia e um nucléolo evidente e central.

Hepatócitos de Solea senegalenses apresentavam um núcleo arredondado eucromático com nucléolo proeminente. Ao redor do núcleo havia duas ou três cisternas de retículo endoplasmático rugoso, não tendo sido observado um complexo de Golgi evidente. O reticulo endoplasmático liso era pouco desenvolvido se localizando na periferia da célula. Um grande número de mitocôndrias e poucos lisossomos estavam dispersos no citoplasma. Lisossomos apresentavam dois tipos morfológicos: arredondados com matriz homogênea muito escura e pleomorfos com conteúdo heterogêneo (ARELLANO; STORCH; SARASQUETE, 1999). Hacking, Budd e Hodson (1977) também observou em teleósteos, um citoplasma rico em lisossomos, que se apresentavam como estruturas arredondadas com uma matriz homogênea escura.

Em peixes, grandes agregados de macrófagos ou melano-macrófagos centrais, normalmente encontrados no sistema linfático e outros órgãos, estão envolvidos em vários processos de fagocitose, armazenamento e detoxificação de bactérias e corpos estranhos (TSUJI; SENO, 1990; FREDELLO et al., 2001).

Micale e Perdichizzi (1990) demonstraram que o crescente número de melano-macrófagos centrais no fígado e baço de peixes é induzido por fatores ambientais. Seguindo observações em Ciclídeos, Fishelson (1996) concluiu que um aumento anormal no número de melano-macrógafos centrais identifica um estresse ambiental.

\subsubsection{Timo}

Segundo Fishelson (2006) o timo em peixes é um órgão linfático primário e o fornecedor central de linfócitos ao sangue, de células $\mathrm{T}$ do sistema imune, como também fonte de timina. Em teleósteos, exerce um importante papel no desenvolvimento do sistema imune totalmente funcional, como demonstrado pela timectomia (NAKANISHI, 1986; TREDE, 1998).

Em várias espécies de peixes, essa glândula produz timosina, uma linfoproteína que estimula a produção de linfócitos em todos os centros linfáticos. $O$ 
tipo de célula dominante no timo é a célula $T$ imunoativa, que é produzida pelo mesmo e amadurece no baço (FISHELSON, 2006).

O timo desenvolve-se a partir de grupos de células endoteliais e mesenquimais, separadas pelas terceira e quarta bolsa de brânquias embrionárias (FISHELSON, 2006).

De acordo com Fergunson (1995) o timo pode ser detectado em algumas espécies de peixes alguns dias antes da eclosão do ovo e, em outros, apenas após a metamorfose da larva. Entretanto, na maioria dos peixes esta glândula se forma e se torna completa e funcional ainda no estágio de embriogênese (FISHELSON, 2006).

Geralmente, se desenvolve na lâmina própria do trato gastrointestinal, em bolsas localizadas na base dos arcos branquiais, que então migram para o mesênquima durante a ontogênese (BOWDEN; COOK; ROMBOUT, 2005). Na maioria dos teleósteos está localizado perto da cavidade da brânquia e está intimamente associado ao epitélio faringeano (CHILMONCZYK, 1992).

Em carpa doméstica o timo surge primeiramente na forma de corpos redondos alongados presos a ambos os lados da base do opérculo e se desenvolvem acima dos arcos branquiais (FISHELSON, 1995). São compostos por massas relativamente soltas de células semelhantes a timócitos jovens, que apresentam um núcleo proeminente (BECKER; FISHELSON; AMSELGRUBER, 2001).

Hibiya (1982) descreveu o timo como um órgão branquiogênico, estando localizado na parede dorsolateral da faringe, a partir do quarto arco branquial. Sua superfície ventral é recoberta por uma mucosa epitelial, onde há uma camada de tecido conjuntivo adjacente. A face dorsal possui uma linha subseqüente de músculos e o parênquima consiste de tecido linfóide, o qual é quase inteiramente composto de linfócitos.

Esta glândula existe em todas as classes de peixes, exceto nos Agnatas, representados pelas lampreias. Infiltrações de linfóides foram observadas no músculo faringeano e acúmulos de linfócitos foram descritos no epitélio faringeaano em larvas de lampreias. O tecido linfóide é localizado no sangue dos sinusoídes, os quais ocorrem na lamina própria faringeana, sendo considerado como um equivalente do timo (CHILMONCZYK, 1992). Entretanto tem sido sugerido que a prega existente no meio de intestino, encontrado em invertebrados e agnatas, pode 
ter atividade tímica em lampreias, tendo sido também sugerido que linhagens de células se diferenciaram e colonizaram diferentes áreas e proliferaram para formar tecidos linfóides sob influencia de fatores ambientais (BOWDEN; COOK; ROMBOUT, 2005).

Em estudos com Apogon annularis, A. cyanosoma, A. cookii, o timo está situado atrás da cápsula ótica, dorsocranialmente à cabeça do rim, e à dissecação é freqüentemente visto como uma marca externa de melanossomas pretos, dispersos na cobertura epitelial (FISHELSON, 2006).

Em peixes, assim como em vertebrados maiores, a involução tímica ocorre devido a variações fisiológicas ou estímulos externos. Está associada principalmente ao envelhecimento, maturidade sexual, induzido por estresse, períodos do ano e hormônios. A involução do timo não é uma regra geral para peixes e pode variar. Depois da incubação, o timo do peixe normalmente aumenta em tamanho e extensão e atinge seu máximo crescimento nas semanas e meses seguintes. $A$ morfologia geral pode parecer a mesma durante toda a vida ou pode sofrer mudanças significativas. Em carpas e tubarões primitivos o timo parece não involuir, enquanto que o timo de grandes raias e tubarões regride (CHILMONCZYK, 1992).

De acordo com Fishelson (1995) e Becker, Fishelson e Amselgruber (2001) essa glândula se diferencia do timo de vertebrados mais desenvolvidos, por permanecer ativa e continuar a aumentar durante o curso de vida dos peixes. Porém, segundo Liu et al. (2004) em Paralichthys olivaceus, ele interrompe o seu desenvolvimento e diminui sua atividade em períodos de reprodução, determinadas épocas do ano e idade, podendo apresentar quadros de involução.

A estrutura característica do timo de peixe é uma cápsula envolvendo um córtex de tecido linfóide. Em zebrafish granulomas foram descritos como agregados de macrófagos dentro da cápsula, formados sem o envolvimento de células $T$ (DAVIS et al., 2002; BOWDEN; COOK; ROMBOUT, 2005).

O parênquima tímico consiste de linfócitos, macrófagos, células dendríticas interdigitantes e células mielóides, havendo no estroma linfócitos com morfologia de células epiteliais. Trabéculas são bem distintas em algumas espécies de peixes (ZAPATA; CHIBA; VARAS, 1996; BOWDEN; COOK; ROMBOUT, 2005).

O timo é composto de células linfóides diferenciadas (timócitos) dentro de uma rede de células epiteliais e geralmente está organizado em zona cortical e medular (MANNING, 1994). Esta demarcação foi baseada na histologia de diferentes 
espécies de peixes (ZAPATA; CHIBA; VARAS, 1996), incluindo a carpa (ROMBOUT et al., 1997). Entretanto, a presença de um córtex e uma medula não é uma constante (TREDE; ZON, 1998) e seus papéis ainda não foram bem definidos (CHILMONCZYK, 1992). Segundo Gorgolon (1983) e De e Pal (1998), diferenciações nas estruturas do timo são muito variáveis entre os teleósteos. Em muitas espécies de peixes não é clara a diferenciação cortico-medular, assim como parece ser em vertebrados maiores (LUER, 1995; DE; PAL, 1998; LIU et al., 2004). Em algumas espécies eles podem estar arranjados para formar um córtex e medula aparentes, com Corpúsculos de Hassall podendo ser observados (FERGUNSON, 1995).

Segundo Bowden, Cook e Rombout (2005) o timo pode ser considerado um agregado de macrófagos encapsulados que funciona como um sistema de proliferação de células $T$.

A presença de uma rede epitelial tímica foi observada em diversas espécies de peixes (ZAPATA; CHIBA; VARAS, 1996), mas uma classificação uniforme de elementos epiteliais e seus possíveis papéis funcionais não foram identificados (ROMANO et al., 1999).

Estruturas linfóides estão situadas na superfície dorsal da cavidade branquial. São cobertas por um epitélio muito fino e possuem um estroma de tecido conjuntivo. O maior número de componentes celulares é de timócitos, porém células epitelióides ou macrófagos e células eosinófilicas granulares também podem estar presentes (FERGUNSON, 1995).

Além dessas células, outros três tipos com extensões citoplasmáticas ramificadas são encontradas no timo: reticulócitos, macrófagos e retículoepiteliócitos (FISHELSON, 2006).

As extensões do retículo-epiteliócito criam uma malha envolvendo grupos de timócitos. As células tronco pluripotentes que formam os reticulócitos também são a fonte dos macrófagos e ambos os tipos de células são muito ativas, especialmente em endocitoses (CHILMONCZYK, 1984; FISHELSON, 1995; BECKER; FISHELSON; AMSELGRUBER, 2001).

Ultraestruturalmente os timócitos são pequenas células com núcleo redondo, com um cariossoma proeminente, cercado por um citoplasma relativamente estreito com pequenas mitocôndrias (FISHELSON, 2006). 
Corpúsculos de Hassall constituem as organelas mais específicas do timo, assim como em vertebrados maiores (FISHELSON, 1995). Em algumas espécies de peixes estudados, eles são corpos redondos de até $30 \mu \mathrm{m}$ de diâmetro, formados por agregados de fagócitos, cercados por um envelope constituído por extensões de reticulócitos, interconectados por numerosos desmossomos. Os Corpúsculos de Hassall juvenis são menores, compreendendo apenas algumas células e uma única camada de células reticulares que as circundam. Com a idade e o crescimento dos corpúsculos, o número de reticulócitos ao redor aumenta (FISHELSON, 2006).

O microambiente tímico, onde ocorre a interação de células do estroma e timócitos, é composto por células epiteliais tímicas e várias outras células do estroma. Estas células foram caracterizadas como células epiteliais tímicas limitantes e as "nurse cells" (XIE et al., 2006) de acordo com a sua distribuição e características citológicas nas áreas internas e externas do timo (ROMANO et al., 1999; XIE et al., 2006).

Células epiteliais tímicas limitantes são observadas na zona subcapsular, subseptal e perivascular, em paralelo com a superfície do timo, delineando a zona apical e a zona exterior. Essas células são eletro-luzentes com projeções alongadas de tonofilamentos. Também são observadas células mucosas nesta zona (CASTILLO et al., 1991; ROMANO et al., 1999; XIE et al., 2006).

As células epiteliais tímicas "nurse cells" são bifurcadas, formando uma rede epitelial tridimensional e apresentam linfócitos viáveis intactos nos vacúolos das suas invaginações. Estas células estão conectadas por desmossomos à sua célula epitelial adjacente formando uma cobertura continua que cobre a zona apical e a divide em outras zonas (PULSFORD et al., 1991; FLAÑO et al., 1996; XIE et al., 2006). Células epiteliais "nurse cell" possivelmente desempenham o papel de formação de um microambiente necessário para a maturação dos timócitos (ROMANO et al., 1999). Estas células foram diferenciadas de outros tipos celulares pela densidade de eletrons no citoplasma pouco eletro-luzentes e vacúolos com conteúdo flocular e por algumas apresentarem inclusões eletro-densas e organelas, como reticulo endoplasmático e mitocôndrias (XIE et al., 2006).

No timo também foram observados linfócitos formando uma rede, conectados por processos citoplasmáticos de diferentes tipos de células epiteliais (ZAPATA; CHIBA; VARAS, 1996; XIE et al., 2006). 


\subsubsection{Baço}

O baço é segundo Banks (1992), a maior massa de tecido linfático do corpo de mamíferos. Exercendo múltiplas funções como formação de células sanguíneas, metabolismo de hemoglobina e ferro, distribuição de hemácias, filtração e armazenamento de sangue. O baço é uma mistura de seios fagocitários, estroma de fibras reticulares e parênquima celular, não havendo a diferenciação de córtex e medula. O parênquima é formado por polpa vermelha e polpa branca.

Em peixes, o baço se apresenta como um corpo plano, elipsóide, com uma coloração vermelha escuro e justaposta ao fígado. Este órgão linfático apresenta uma citologia muito mais heterogênea do que o timo. Ele é constituído internamente por células do retículo endotelial dos quais seus processos formam lóbulos contendo grupos de células brancas e vermelhas (FISHELSON, 2006).

A superfície do baço é revestida por uma membrana serosa que é constituída principalmente por tecido conjuntivo. Uma parte desta cápsula estende-se internamente, formando uma rede trabecular. A artéria que entra gradualmente dentro do baço se ramifica em pequenos vasos e forma uma rede de capilares. $O$ baço é constituído por essas duas redes e por células que preenchem os espaços dentro das redes. Essas células são compostos por eritrócitos, linfócitos e macrófagos (HIBIYA, 1982; ZAPATA, 1982).

Citologicamente, o baço em peixes teleósteos é muito similar aquele de vertebrados maiores (QUESADA; VILLEVA; ANGULLEIRO, 1990). Apresenta uma separação pronunciada muito menor na polpa vermelha, contendo uma rede de cordões e polpa branca com tecido linfático (IWAMA; NAKANISHI, 1996).

No baço de Osteictes, não há distinção entre polpa vermelha e polpa branca como ocorre em baço de mamíferos. As regiões ricas em eritrócitos e linfócitos são misturadas (HIBIYA, 1982).

Para Zatapa (1982) essas regiões são bem distintas em Rutilus rutilus e Gobio gobio e estão frequentemente associadas ao tecido pancreático. Para ele a polpa branca desta espécie é constituída por células linfóides dispostas em densos grupos dentro de redes de células reticulares. 
Sailendri e Muthukkaruppan (1975) descreveram o baço de Tilapia mossambica como sendo constituído por polpa vermelha e branca, sendo que a polpa vermelha é totalmente eritróide, com muito poucos linfócitos. A polpa branca é constituída por redes reticulares ao redor de vasos sanguíneos, sendo bem pequena e pobremente desenvolvida e estas áreas apresentaram vários tipos celulares como granulócitos, monócitos e eritrócitos.

Trabéculas são frequentemente encontradas no baço de teleósteos e se apresentam como invaginações de tecido conjuntivo no parênquima do baço com vasos e artérias no seu interior (SAILENDRI; MUTHUKKARUPPAN,1975; HIBIYA, 1982; ZATAPA, 1982).

Segundo Liu et al. (2004), o baço foi observado em Paralichthys olivaseus no oitavo dia de encubação, porém ficou mais visível no décimo primeiro dia. Está localizado dorsalmente ao mesogástrio e perto do tecido pancreático. Mostrou-se como uma massa sólida de células, com formato esférico, não havendo distinção entre polpa vermelha e polpa branca, tanto em jovens como em animais adultos.

No baço dos teleósteos, recipientes sanguíneos elipsoidais são menos desenvolvidos do que no baço de elasmobrânquios, mas são organizados de acordo com o mesmo padrão, com capilares terminais que mostram uma fina camada de células endoteliais, cercada por uma fina bainha de fibras reticulares e macrófagos (YOFFEY, 1929).

Junto à proliferação de células vermelhas do sangue, o baço de teleósteos é muito rico em macrófagos, que podem funcionar não apenas como sistema de defesa, mas também produzindo hidrolases lisossomais, proteínas do sistema complemento e parcialmente interferon, superóxido e radicais hidróxidos. O baço contém numerosos neutrófilos e eosinófilos, tornando essa glândula um grande local de fagocitose de matéria particulada e células sanguíneas, bem como de atividade hematopoiética (FISHELSON, 2006).

Alguns autores também analisaram o padrão histoenzimático de macrófagos elipsoidais do baço do teleósteo, observando suas similaridades a zona marginal de macrófagos do baço de mamíferos (YOFFEY, 1929; PRESS; DANNEVIG; LANDSVERK, 1994). Uma zona marginal limitando a polpa branca e vermelha não está presente no baço de teleósteo e, de acordo com estudos de microscopia de varredura em moldes de corrosão vascular, a circulação esplênica está aberta aos 
capilares arteriais que terminam na rede reticular da polpa vermelha (KITA; ITAZAWA, 1990).

A ligação antígena, resposta e produção de anticorpos foram observadas em trutas e esplenócitos podem ser estimulados indiretamente, sugerindo a presença de células T e B no baço de teleósteos (IWAMA; NAKANISHI, 1996).

Funções do tecido linfóide esplênico de teleósteos permanecem controversas, embora seu papel no processamento antigênico pareça certo. A esplenectomia não tem efeito em respostas humorais em alguns teleósteos, apesar de, em outras espécies, o baço aparentemente represente um importante órgão linfóide (YU et al., 1976).

Tatner (1985) observou uma migração preferencial de timócitos dentro do baço de trutas, havendo um maior envolvimento do baço em respostas imunes secundárias.

Para Zapata (1981) em Gobio gobio e Rutilus rutilus, ultraestruturalmente as células que constituíam a rede reticular eram grandes e de forma irregular com muitos filamentos citoplasmáticos que se ligavam entre si por desmossomos. Os linfócitos se caracterizaram por seu citoplasma escasso e núcleo altamente eletrodenso. Os linfoblastos se mostraram como células grandes com núcleos pouco eletro-densos e citoplasma abundante com muitos polissomos. Plasmócitos continham retículo endosplamático rugoso e mitocôndrias eletro-densas dispersas em seu citoplasma.

Melano-macrófagos foram observados no tecido hematopoiético de baço de Trichogaster leeri e Xiphophorus maculatus e eram compostos de grupos de células normalmente encapsulados por uma camada celular fina, também se apresentando como células dispersas Essas células contêm grandes quantidades de pigmentos de ferro livre, provavelmente lipofucsina, podendo ter um significante papel como depósito e desnaturação de lipoproteínas, não parecendo desempenhar nenhum papel significante no manejo de ferro (LEKNES, 2004, 2007).

Descrições ultraestruturais das células que compõem o parênquima do baço foram raramente encontradas. 


\subsection{LEUCÓCITOS}

Peixes, da mesma forma que mamíferos, possuem leucócitos que são produzidos por diferentes órgãos, com diferentes funções. Estas células, em teleósteos, são produzidas pelo rim cefálico, fígado, baço e timo e a maioria realiza funções de defesa imune. São classificados conforme a sua morfologia, ultraestrutura e marcação histoquímica em monócitos, macrófagos, melanomacrófagos, linfócitos, granulócitos (neutrófilos, eosinófilos e basófilos) e células citotóxicas não-específicas (CAMPBELL, 1988; ROWLEY et al., 1988; FÄNGE, 1994; IWAMA, 2004). Porém, diferentemente de mamíferos, não há marcadores de superfície celular conhecidos em número suficientes para estas células, os quais seriam usados no reconhecimento e no estudo de sub-populações funcionais de leucócitos. (CAMPBELL, 1988; FÄNGE, 1994; PASTORET et al., 1998).

Os peixes estão desprovidos de medula óssea e de linfonodos, desta forma os tecidos mielóide e linfóide estão associados ao mesmo órgão, sendo o tecido linfóide de maior ou menor complexidade dependendo da posição do peixe na escala filogenética (TAVARES-DIAS; MORAES, 2004).

O volume do sangue de peixes varia entre 2 - $6 \%$ do volume do corpo e em conjunto com a linfa, controla homeostaticamente o ambiente interno. As células vermelhas (eritrócitos) usualmente constituem $98-99 \%$ das células do sangue (FÄNGE, 1994).

Ellsaesser et al. (1985) identificaram no sangue periférico de Ictalurus punctatus pelo menos quatro tipos de células: os linfócitos, trombócitos, monócitos e neutrófilos e classificou a ausência ou presença de eosinófilos e basófilos devido a classificação e designação destes tipos celulares na literatura. Kfoury et al. (1999) descreveram populações celulares no sangue periférico de truta arco Iris. Estas populações eram constituídas pelas mesmas células encontradas em outras espécies, excerto pela diferenciação entre linfócitos grandes e pequenos.

Esteban et al. (2000) descreveu duas populações celulares no sangue de Dicentrarchus labrax, uma constituída de pequenas e outra de células grandes. Essas populações eram formadas por eritrócitos imaturos e maduros, trombócitos, 
granulócitos heterofilicos e acidofílicos, linfócitos, plasmócitos e monócitosmacrófagos.

\subsubsection{Monócitos-Macrófagos}

Segundo Fänge (1994) os monócitos constituem a menor população de células brancas do sangue. Seu núcleo é grande e oval, apresentando um citoplasma sem granulação. São células fagocíticas e pertencem à mesma linhagem celular de macrófago dos tecidos. Podendo existir um tipo celular intermediário entre macrófagos e granulócitos

Kfoury et al. (1999) observaram que os monócitos de truta arco-iris apresentaram um núcleo bilobado em formato de rim e uma grande quantidade de reticulo endoplasmático rugoso, muitos grânulos, vesículas e vacúolos dispersos em seu citoplasma. Estas células tinham em média $8-20 \mu m$.

Os monócitos dão origem aos macrófagos quando estes migram para os tecidos (TIZARD, 2002).

Segundo Lorenzi (1999) os macrófagos possuem morfologia variável e são mais ativos que os monócitos dos quais se derivam. Em mamíferos os macrófagos estimulados adquirem um aspecto de células gigantes policariontes. Este fato também foi descrito em Paulicea lutkeni, Oncorhyncus mykiss, Oreochromis niloticus e Piaractus mesopotamicus (TAVARES-DIAS, 2004).

\subsubsection{Melano- Macrófagos Centrais}

Melano-macrófagos centrais são aglomerados de melano-macrófagos que contém inclusões heterogêneas, sendo as mais freqüentes a melanina, hemossiderina e lipofucsina (AGIUS; AGBEDE, 1984).

Estes agregados de células contêm pigmentos que estão presentes nos tecidos hematopoiéticos do baço e rim e nas áreas periportais do fígado, mas seu grau de organização varia entre as espécies. Em algumas espécies os centros são 
limitados por uma fina cápsula argirofílica, rodeada por polpa branca e associado a vasos estreitos (AGIUS, 1980; ELLIS; ROBERTS; TYTLER, 1989). Entretanto, em salmonídeos, acúmulos de melano-macrófagos são pouco definidos e com ausência de uma cápsula, porém a associação com vasos sangüíneos e linfócitos está presente (PRESS; DANNEVIG; LANDSVERK, 1994).

Os melano-macrófagos centrais podem ser considerados depósitos metabólicos, mas a sua capacidade de reter antígenos por longos períodos, possivelmente na forma de complexos imunes, compara-se aos centros germinativos dos vertebrados superiores (FERGUSON, 1976; AGIUS, 1980).

\subsubsection{Granulócitos}

Granulócitos podem ser sub-divididos em neutrófilos, eosinófilos e basófilos. Neutrófilos e eosinófilos são os tipos mais comuns, com basófilo ausente na maioria das espécies. Assim como macrófagos, os granulócitos podem ser isolados do sangue, tecidos linfóides e cavidade peritonial (MAINWARING; ROWLEY, 1985; ROWLEY et al., 1988).

Neutrófilos são granulócitos altamente móveis, fagocíticos e produzem oxigênio reativo, mas sua atividade bactericida é relativamente pequena se comparada aos macrófagos. Assim como os macrófagos, eles parecem possuir região efetora e receptores para complemento, como evidenciado em estudos de opsonização. Células granulares encontradas no extrato granuloso do intestino, brânquias, pele, meninges e rodeando vasos sanguíneos maiores não são considerados eosinófilos (VALLEJO; ELLIS; ROBERTS; TYTLER, 1989).

Os granulócitos também são divididos em granulócitos heterofílicos e granulócitos acidofílicos. Os granulócitos heterofílicos são células arredondadas a ovais irregulares com processos celulares curtos. Apresenta núcleo grande bilobado ou trilobado excêntrico e citoplasma granular. Os granulócitos acidofílicos são células redondas com núcleo excêntrico bilobado e um citoplasma translúcido (ESTEBAN et al., 2000; VÁZQUEZ; GUERRERO, 2007). 


\subsubsection{Linfócitos}

Os linfócitos constituem aproximadamente metade das células brancas do sangue e são caracterizadas por um núcleo redondo e um citoplasma basófilo agranular, sendo responsáveis por respostas imunes (FÄNGE, 1994).

Segundo Kfoury et al. (1998), existem duas populações de linfócitos morfologicamente distintas em Oncorhynchus mykiss, as quais diferem basicamente em seus tamanhos e presença de grânulos, com tamanhos médios entre 3-6um.

Alguns leucócitos, com características ultra-estruturais de linfócitos foram observados contendo ácido-fosfatase positivo citoplasmático granular, não estimulados na cavidade peritonial de truta arco-íris (AFONSO; ELLIS; SILVA, 1997). Foi observado que essas células podem corresponder a células citotóxicas não específicas, ou às células natural killer, devido as suas similaridades com essas células de mamíferos. Sobre esta questão também há controvérsias, visto que Greenle et al. (1991) relatou que em trutas, células citotóxicas não específicas não são granulares.

Segundo Vázquez e Guerrero (2007) os linfócitos são células pequenas e redondas. Possui um núcleo grande, esférico que ocupa quase toda célula. Ultraestruturalmente os linfócitos apresentam processos celulares semelhantes a dedos, apresentando dimensões em Cichlasoma dimerus entre $3.4-4.7 \mu \mathrm{m}$. São os leucócitos mais comuns no sangue de algumas espécies de peixes, apresentando uma grande diversidade no aspecto morfológico e tem sido descrito com diferentes nomes por diferentes autores.

\subsubsection{Células Granulocíticas Especiais}

Células granulocíticas especiais ou leucócitos granular PAS-positivo são geralmente grandes e muito semelhantes aos neutrófilos, seu núcleo é pequeno e excêntrico com cromatina densa sem presença de nucléolos (TAVARES-DIAS, 2004). 
Ribeiro (1978) estudou esta célula no sangue de Pimelodus maculatus e observou grânulos no seu citoplasma de tamanho, forma e opacidade variados.

Sua freqüência no sangue de peixes das famílias Characidae, Ciprinidae, Erythrinidae, Prochilodontidae é relativamente baixo e não foi observado em espécies das famílias Salmonidae, Ictaluridae, Mugilidae e Cichlidae (TAVARESDIAS, 2004), ocorrendo freqüentemente apenas em alguns grupos taxonômicos (BARBER; WESTERMANN, 1978).

Granulócitos semelhantes a essas células em Cyprinus carpio, foram caracterizados como célula reticular fina e como granulócito tipo 2 por alguns autores (TAVARES-DIAS; MORAES, 2004).

\subsubsection{Trombócitos}

Trombócitos são as células mais abundantes do sangue, depois dos eritrócitos (UEDA et al., 1997), entretanto alguns autores não incluem trombócitos dentro de leucócitos (VÁZQUEZ; GUERRERO, 2007).

Para Campbell (1988) trombócitos apresentam forma arredondada, alongado ou em formato de haste, podendo variar devido ao estágio de maturidade ou no estágio de reatividade. Segundo ele os trombócitos que apresentam as formas redondas são os imaturos em algumas espécies de peixes, o formato de haste são as formas reativas, não se referindo a forma alongada. Os núcleos seguem o formato da célula apresentando cromatina densa.

Segundo Tavares-Dias e Moraes (2004) os trombócitos são células predominantemente elípticas com núcleo fusiforme.

De acordo com Fange (1994) os trombócitos são ovais ou apresentam formato de haste com um núcleo compacto central.

No teleósteo Ictalurus punctatus Cannon et al. (1980) descreveu trombócitos com forma ovóide alongada.

Em Cichlasoma dimerus trombócitos apresentaram diferentes morfologias, com eixo fusiforme ou formas ovais com núcleo oval localizado centralmente. 0 tamanho dessas células variou entre 8 - $8.9 \mu \mathrm{m}$ de comprimento e 2.1 - $2.7 \mu \mathrm{m}$ de largura e apresentaram citoplasma translúcido (VÁZQUEZ;GUERRERO, 2007). 
Kfoury Jr. (1999) descreveu trombócitos sendo caracterizados por seu formato irregular, variando de arredondado a alongado apresentando um citoplasma com um extenso sistema de canículos e bandas proeminentes de microtúbulos. Seu tamanho foi de $7-20 \mu \mathrm{m}$ de comprimento e 3 - $5 \mu \mathrm{m}$ de largura.

\subsubsection{Eosinófilos}

Os eosinófilos são células arredondas e relativamente pequenas. O citoplasma é escasso e ocupado por grânulos. O núcleo é geralmente excêntrico e ocupa grande parte da célula (TAVARES-DIAS; MORAES, 2004). Podendo também apresentar um citoplasma escasso de superfície irregular com projeções que levam a formação de pseudopodes como observado em Salminus maxilosus (VEIGA et al., 2000). Apresentou tamanhos entre 4.8 - $9.5 \mu \mathrm{m}$ (VEIGA et al., 2000; VÁSQUEZ; GUERREIRO, 2007))

\subsubsection{Neutrófilos}

Segundo Tavares-Dias et al. (2002) neutrófilos apresentam o núcleo na forma de bastonete ou ocasionalmente segmentado. Se apresentando oval, excêntrico e formando lóbulos incompletos em algumas espécies de peixes teleósteos (VEIGA et al., 2000). Se mostrando muito semelhante aos neutrófilos de mamíferos. 


\section{MATERIAL E MÉTODOS}

Os animais e a metodologia utilizados neste trabalho estão descritos a seguir.

\subsection{MATERIAL}

O experimento foi desenvolvido no Laboratório de Técnicas Imunológicas Aplicado à Morfologia (LTIAM), no Departamento de Cirurgia da Faculdade de Medicina Veterinária e Zootecnia da Universidade de São Paulo - Universidade de São Paulo. Os animais mantidos no criatório XV de Novembro Piscicultura, localizado no município de São João da Boa Vista - SP, Rodovia São João-Aguaí $\mathrm{Km} 221,5$, foram retirados dos tanques de manutenção e colocados em piscinas de aclimatação com capacidade de 1000 I, abastecido com água corrente declorificada por 5 dias antes do início do experimento.

Foram utilizados 30 espécimes de pacu, Piaractus mesopotamicus, juvenis com idades que variaram entre 5 meses a um ano, com peso médio de $588.1 \mathrm{~g}$ (mínimo de $160 \mathrm{~g}$ e máxima de $1340 \mathrm{~g}$ ) e comprimento total médio de $27.51 \mathrm{~cm}$ (mínimo de $19 \mathrm{~cm}$ e máximo de $37 \mathrm{~cm}$ ).

Para retirada dos órgãos linfóides e coleta do sangue, os animais foram anestesiados e eutanasiados em solução de benzocaína a 50 ppm em solução aquosa (1g de benzocaína em $20 \mathrm{~L}$ de água), segundo parecer e autorização do Comitê de Bioética da Faculdade de Medicina Veterinária e Zootecnia da USP- SP.

O sangue foi coletado pela artéria caudal, tendo sido obtido em média $8 \mathrm{ml}$ de sangue em peixes com peso médio de $1075 \mathrm{~g}$ e comprimento médio de $33.71 \mathrm{~cm} \mathrm{e}$ $2 \mathrm{ml}$ de sangue em exemplares com peso médio de $417.5 \mathrm{~g}$ e comprimento médio de $25.35 \mathrm{~cm}$. Após completa cessação dos movimentos operculares, foi feita a abertura da cavidade abdominal através de incisão ventral. Obteve-se uma janela onde os órgãos foram fotografados in situ antes de serem retirados. 
Depois dos órgãos retirados, pequenos fragmentos foram obtidos e estes fixados em Paraformaldeído 4\% PBS para microscopia de luz e em Karnovsky para microscopia eletrônica de transmissão.

Para o estudo anatômico, os órgãos foram fotografados in situ com o uso de máquina digital.

\subsection{MÉTODOS}

\subsubsection{Microscopia de Luz}

Os órgãos do sistema linfóide foram removidos e obtidos fragmentos que foram fixados em solução de paraformaldeído 4 \% em PBS (Dulbecco's phosfate buffer saline-DPBS, Gibco Co, USA). As amostras foram processadas segundo a técnica de Behmer, Tolosa e Freitas-Neto (1976), em séries crescentes de álcoois, até o álcool absoluto e em seguida incluído em paraplast. Posteriormente, os fragmentos foram cortados com espessura de $4 \mu \mathrm{m}$ e corados pelas técnicas de Hematoxilina-Eosina.

Foram retirados cortes com espessura de $4 \mu \mathrm{m}$ do material embebido em Histosec $\AA$ com o uso de micrótomo.

O material fixado com Mc Dowell e parte do material fixado com Karnovsky foram incluídos em Historresina, para tanto passou por duas séries de álcoois $(70 \%$ e 90\%), álcool-resina, resina e foi emblocado em Historresina. Posteriormente, as amostras foram cortadas em micrótomo em espessura de $1 \mu \mathrm{m}$ e coradas pelas técnicas de Hematoxilina-Eosina.

Para análise dos leucócitos foram feitos esfregaços de uma gota de sangue sobre a lamina, seco em temperatura ambiente e mergulhadas em solução GiemsaMay Grünwald (BEHMER; TOLOSA; FREITAS-NETO, 1976) e Panótico Rápido.

As colorações de Panótico Rapido e Giemsa-May Grünwald foram feitas para observação dos leucócitos, seus núcleos e granulações basófilas e acidófilas. 


\subsubsection{Microscopia Eletrônica de Transmissão}

Os fragmentos obtidos dos órgão linfóides rim cefálico, fígado, timo e baço foram fixados em Karnovsky. Após um período de fixação não inferior a $24 \mathrm{~h}$ as amostras foram lavadas em sacarose e pós-fixadas em tetróxido de ósmio 1\% (osmium tetroxide $4 \%$ solution in water, Polyscience, Inc. USA). Desidratadas em concentrações crescentes de etanol e submetido a dois banhos em solução de Óxido de propileno (Propylene oxide EM Grade - Polysciences ${ }^{\circledR}$, Inc. USA) puro. Incluído em uma solução de óxido de propileno e Spurr's (Spurr's kit - Electron Microscopy Sciences, Co. USA), na proporção 3:1 por 1 hora sob agitação. Decorrido este período o material foi colocado em óxido de propileno e resina Spurr's (1:1) por 1 hora sob agitação constante, em seguida foi realizada a troca de concentração de óxido propileno e Spurr's na proporção (1:3) mantendo o material sob mesma condição por 2 horas e posteriormente colocado em Araldite pura por 8 horas. Os fragmentos foram colocados em moldes de silicone contendo resina pura e permaneceram em estufa $60^{\circ} \mathrm{C}$ por 72 horas para polimerização da resina.

Após a embebição, procedeu-se a trimagem do bloco e à seguir o material foi cortado em ultramicrótomo da marca RMC modelo MT- RL efetuando-se cortes ultrafinos com 70nm - $90 \mathrm{~nm}$ de espessura que foram colocados em grids de cobre de 200 mesh, corados com acetato de uranila 3\% e citrato de chumbo e observados e fotografados no Microscópio Eletrônico de Transmissão Philips Morgagni 268 D, na Faculdade de Medicina Veterinária e Zootecnia da Universidade de São Paulo, Departamento de Cirurgia e Setor de Anatomia (FMVZ-USP). 


\section{RESULTADOS}

\subsection{ANÁLISE MACROSCÓPICA}

Os órgãos linfóides de Piaractus mesopotamicus, rim cefálico, baço e fígado se localizam na cavidade celomática, enquanto o timo está localizado na cabeça (Figura 1).

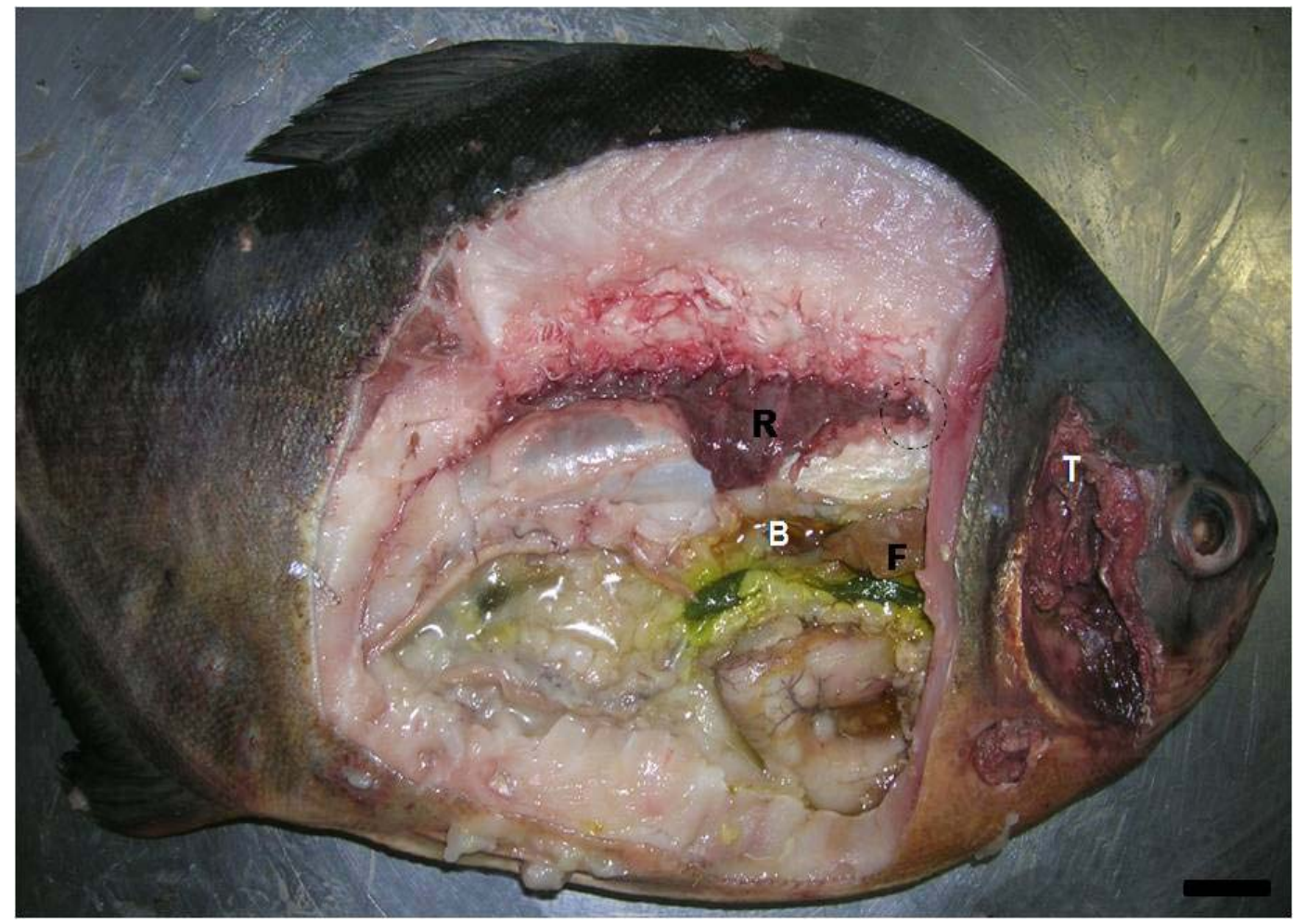

Figura 1 - Fotografia em vista lateral do Piaractus mesopotamicus, evidenciando a disposição dos órgãos "in situ": rim $(\mathrm{R})$, rim cefálico (circulo pontilhado), baço $(B)$, timo $(T)$ e fígado $(F)$. Barra: $1 \mathrm{~cm}$ 


\subsubsection{Rim}

O rim está localizado retroperitonealmente na região dorsal da cavidade celomática. Encontra-se separado desta por uma membrana, localizando-se dorsalmente à bexiga natatória e ventralmente à coluna vertebral, estando inserido entre as costelas o que dificulta a sua remoção. Tem um formato em "H", sendo que a região média se expande lateralmente sobre a bexiga natatória, região essa de encontro entre as porções cranial direita e esquerda e caudal direita e esquerda do rim (Figura 2A).

Possui uma consistência gelatinosa de coloração vermelha viva (Figura 2A e 2B).

\subsubsection{Rim Cefálico}

O rim cefálico localiza-se na porção cranial do rim, caudalmente ao crânio e dorsalmente a porção cranial da bexiga natatória. Lateralmente à região cervical da coluna vertebral, ele apresenta uma porção direita e uma esquerda e consistência gelatinosa e de coloração vermelho vivo (Figura 2A). O rim cefálico, em animais com idade mais avançada, apresentou-se como uma dilatação na porção cranial do rim (Figura 2A). O que não foi observado em animais jovens. 

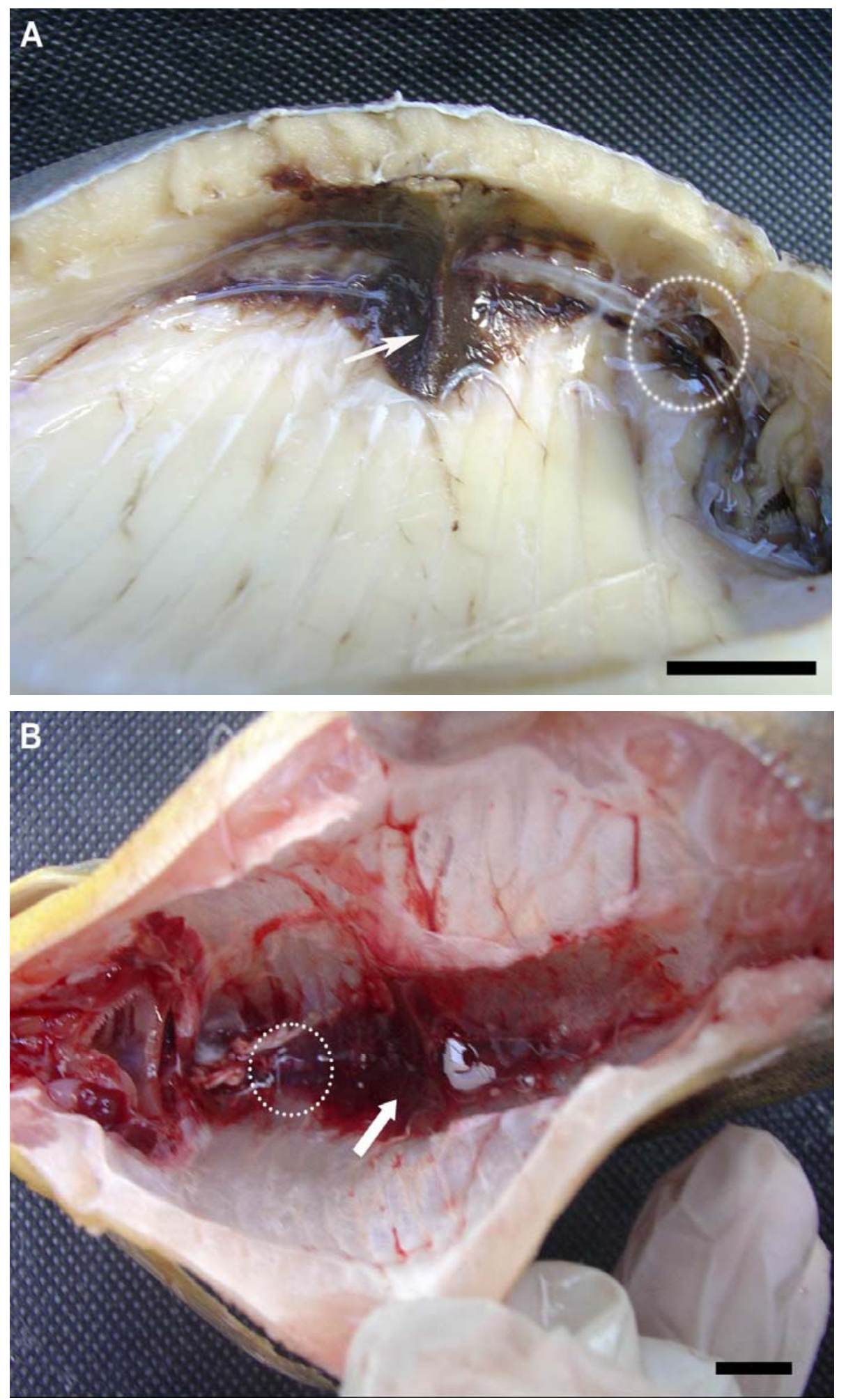

Figura 2- Fotografia dos órgãos "in situ" do Piaractus mesopotamicus. A: Visão lateral da região média do rim em forma de " $H$ " (seta), dilatação do rim cefálico (círculo pontilhado).Animal com 8 meses de idade:fixado em formol 10\%,Barra: $1,5 \mathrm{~cm}$ B: Posição em decúbito dorsal, rim (circulo pontilhado) e rim cefálico (seta). Não é possível observar uma clara distinção entre os dois órgãos. Animal com 4 meses de idade a fresco. Barra: $3 \mathrm{~cm}$ 


\subsubsection{Fígado}

Entre o fígado e a cabeça existe uma membrana que separa a cavidade celomática da cabeça (Figura $3 \mathrm{~A}$ ). O fígado está localizado caudalmente a esta membrana, na porção cranial da cavidade celomática (Figura 3B). É cranial ao estômago, ventral a porção cranial da bexiga natatória e dorsal ao intestino (Figura 3B).

Apresenta coloração vermelha viva a amarronzada. Constituído por três lobos que foram descritos como lobo dorsolateral direito e esquerdo e lobo ventral. $O$ lobo dorsolateral direito e esquerdo estão localizados dorsalmente ao estômago e intestinos, apresentando em sua superfície ventral, a impressão do intestino e, na superfície dorsal a impressão da bexiga natatória. O lobo ventral está localizado cranialmente ao estômago e dorsalmente ao esôfago e apresenta a impressão dos mesmos (Figura 3C).

A vesícula biliar se estende desde o lobo ventral do fígado por toda cavidade celomática. Está dividida em três porções: uma porção cranial, localizada no lobo ventral do fígado; uma porção média que apresentou um estreitamento na sua estrutura e está localizada dorsalmente ao estômago e uma porção caudal que se localiza caudalmente ao estômago e ventralmente à bexiga natatória. (Figura 5A). 

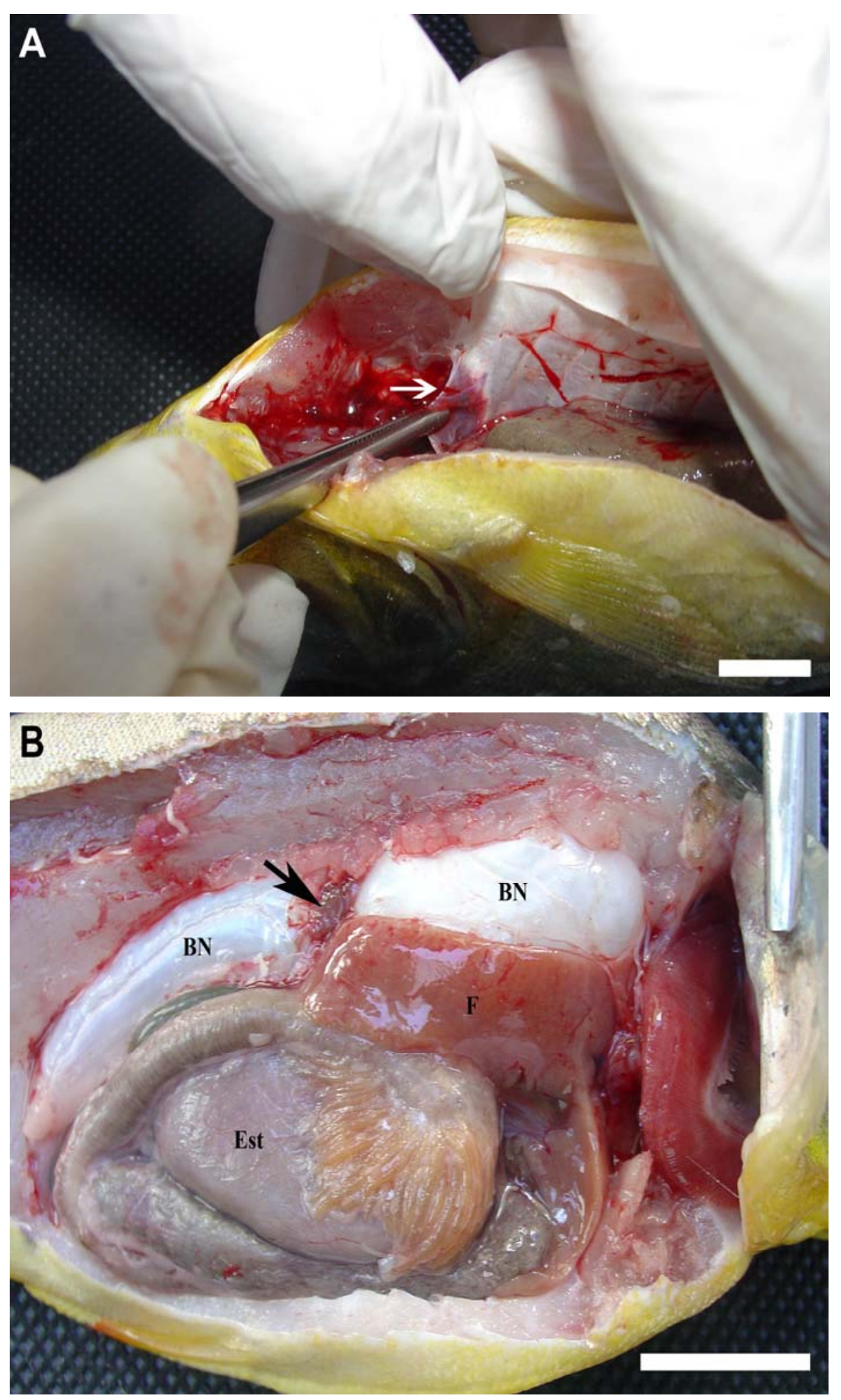


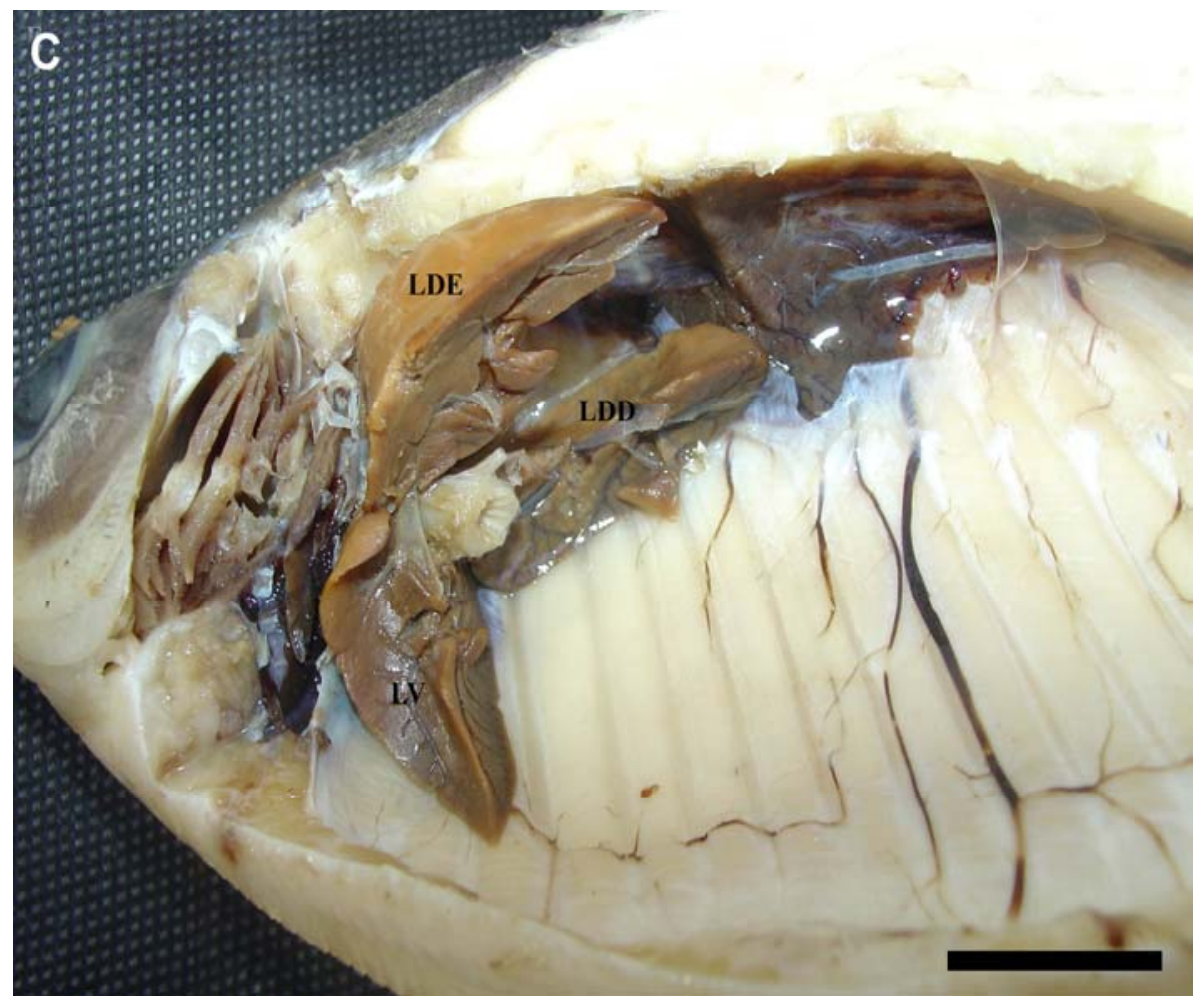

Figura 3- A: posição em decúbito dorsal, nota-se a membrana que separa a cavidade celomática da cabeça (seta). Barra: $1,5 \mathrm{~cm}$. B: visão lateral do lobo dorsolateral direito do fígado $(F)$, dorsal a este lobo a bexiga natatória $(B N)$, observamos o lobo ventral evidenciando impressão do estômago (Est) e a expansão lateral do rim sobre a bexiga natatória (seta). Barra: $3 \mathrm{~cm}$. C: visão lateral esquerda do fígado evidenciando o lobo dorsolateral direito (LDD) e esquerdo (LDE) e lobo ventral (LV). Barra: $3 \mathrm{~cm}$

\subsubsection{Timo}

O timo é um órgão par bilateral, localizado na porção caudal da cabeça, dorsalmente às brânquias na cavidade do opérculo e encontra-se protegido por uma cápsula membranosa. Em animais jovens sua localização e acesso foram mais difíceis que em animais com mais de cinco meses de idade, em decorrência do pequeno tamanho do animal. Apresenta uma forma difusa de consistência gelatinosa, com coloração variando de vermelha viva à vermelha escura (Figura 4). 


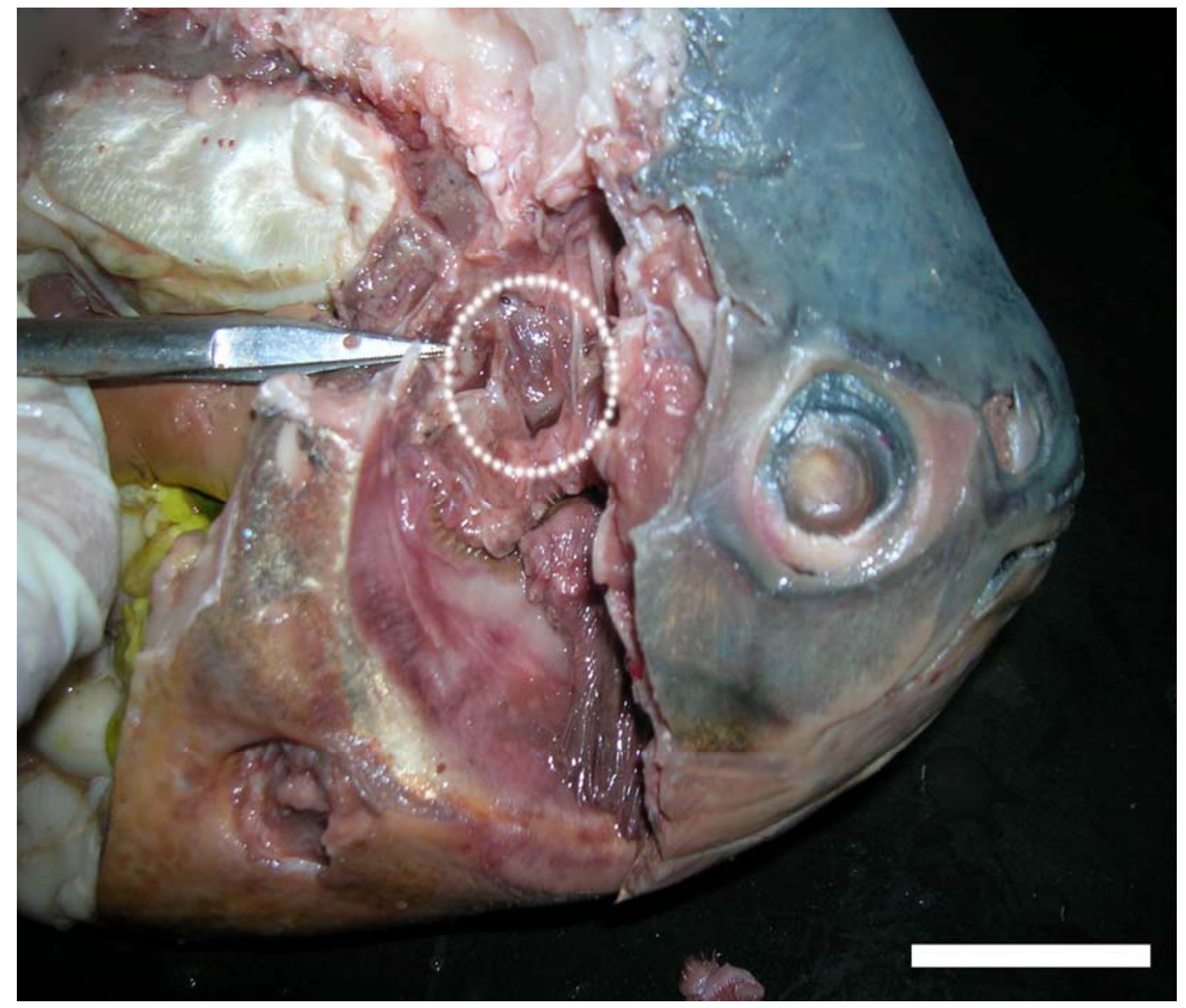

Figura 4- Visão lateral direita do timo direito (circulo). Barra: $3 \mathrm{~cm}$

\subsubsection{Baço}

O baço se localiza caudo-dorsalmente aos lobos dorsolaterais do fígado, ventralmente à bexiga natatória e dorsalmente à porção média caudal da vesícula biliar. Apresenta um formato piramidal, achatado dorsoventralmente, com uma superfície lisa em animais jovens e lobada em adultos, estando protegido por uma membrana. Apresenta coloração vermelho escura e consistência firme, compacta (Figura 5). 


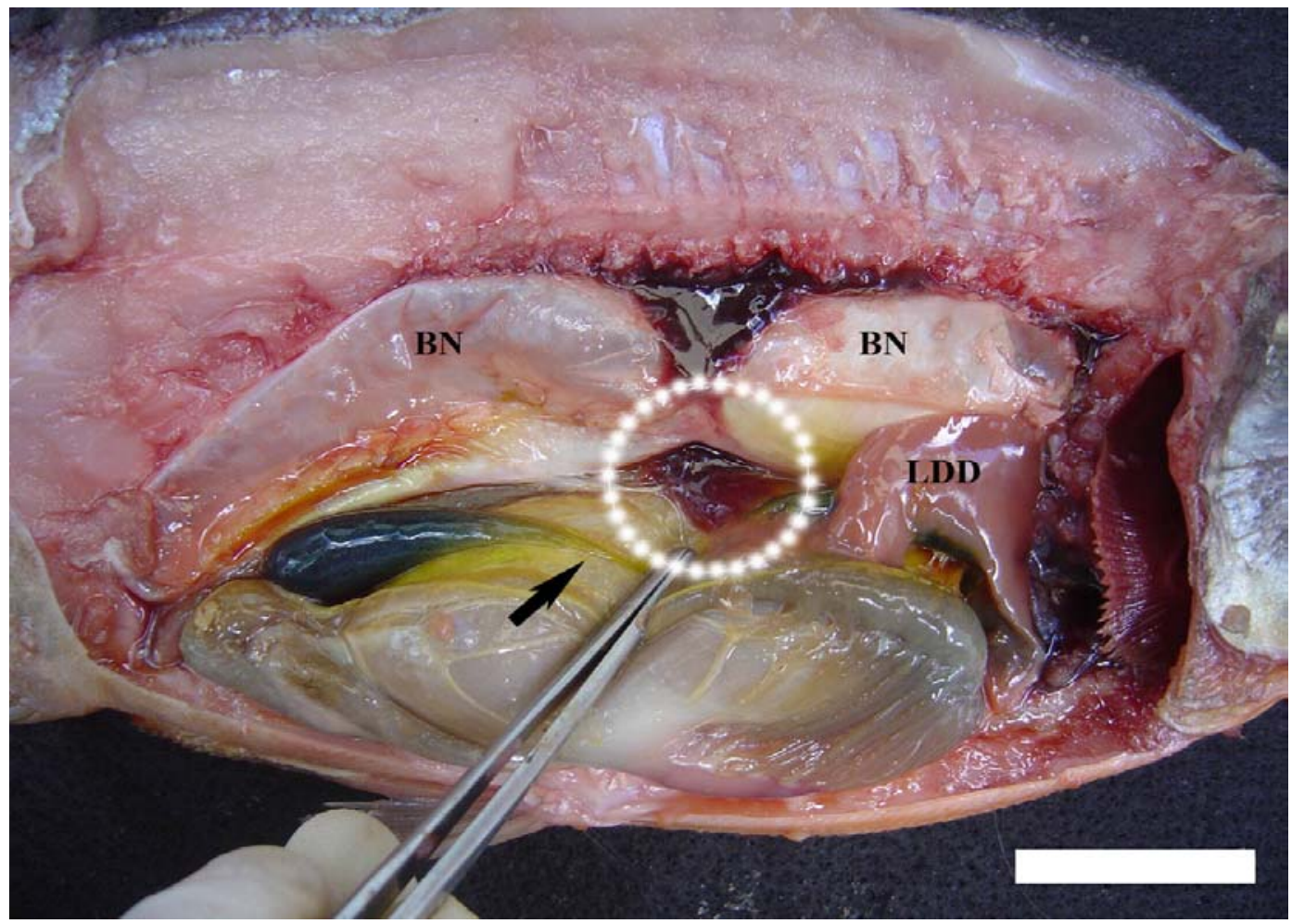

Figura 5- Vista lateral direita do baço (circulo pontilhado), caudalmente ao lobo dorsolateral direito (LDD), ventralmente a bexiga natatória (BN) e dorsalmente a porção média da vesícula biliar (seta). Barra: $1,5 \mathrm{~cm}$ 


\subsection{ANÁLISE MICROSCÓPICA}

\subsubsection{Rim}

No parênquima do rim são encontrados glomérulos que são formados por capilares. Apresentam cápsula de Bowman onde é observada a presença de dois folhetos: a camada visceral e a camada parietal da cápsula de Bowman. Nela observam-se células pavimentosas com núcleo achatado constituindo a parede parietal e uma membrana muito fina, quase imperceptível, constituindo a camada visceral. Esta membrana limita a área das células que se encontram no interior do glomérulo. Estas células são na sua maioria hemácias, linfócitos, trombócitos e células imaturas (Figura 6A).

O seu estroma é constituído por células hematopoiéticas e linfocíticas, sendo que foi observado melano-macrófagos e infiltrados mononucleares dispersos pelo tecido conjuntivo (Figura 6A).

Os túbulos contorcidos proximais são constituídos por um epitélio cúbico simples, com núcleo redondo basal (Figura 6B) e as células do seu epitélio apresentam borda em escova e a luz do túbulo era central reduzida. Os túbulos contorcidos distais são formados por um epitélio cúbico baixo, com núcleos redondos basais e também apresentam uma luz central reduzida. Também formam observados glomérulos constituindo o parênquima (Figura 6B).

Veias de grande calibre contendo hemácias e leucócitos estão presentes no tecido conjuntivo do órgão. Pequenos capilares e arteríolas também são observados no tecido conjuntivo (Figura 6B). 

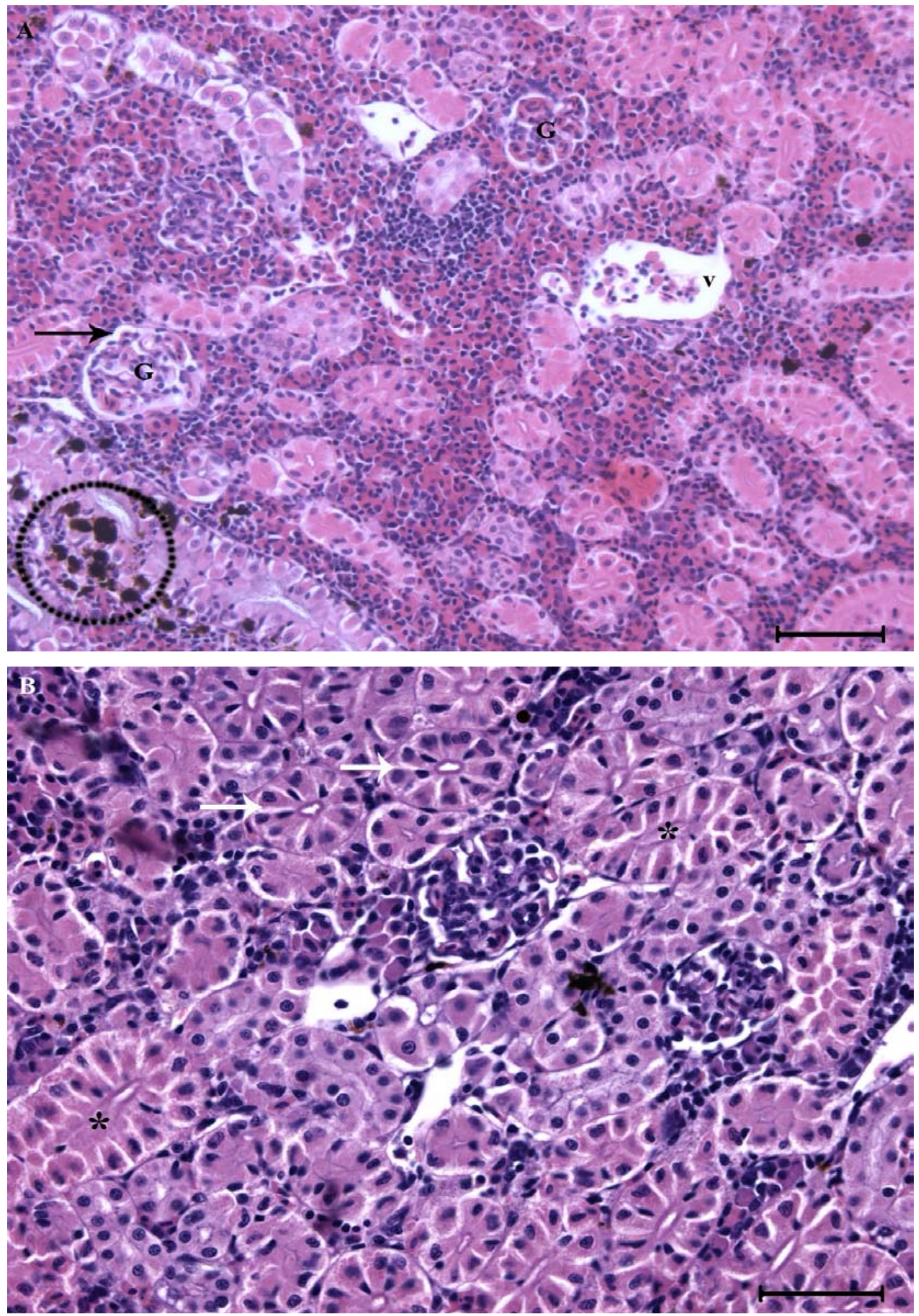

Figura 6- Fotomicrografia A: no rim, glomérulos (G) e cápsula de Bowman (seta), vasos sangüíneos $(V)$ e melano-macrófagos (circulo pontilhado) dispersos no citoplasma. Barra: $50 \mu \mathrm{m}$ B: túbulos contorcidos proximais, epitélio cúbico simples (seta) e túbulos contorcidos distais com epitélio cúbico baixo com luz central reduzida $\left(^{*}\right)$. Coloração HE. Barra: $40 \mu \mathrm{m}$ 


\subsubsection{Rim Cefálico}

No rim cefálico o epitélio de revestimento é formado por uma camada de células pavimentosas com núcleo achatado, seguido por uma camada de tecido conjunto frouxo e uma camada de tecido adiposo unilocular. Vasos sanguíneos são observados no tecido conjuntivo e, em algumas regiões, grandes vasos estão associados ou ao lado de uma arteríola. Células de gordura envolvidas por tecido conjuntivo foram observadas constituindo o rim cefálico de animas com mais de seis meses de idade, o que não foi observado em animais mais jovens (Figura 7A).

A região cortical é formada por infiltrados mononucleares, principalmente linfocíticos. Nestas regiões também são observados alguns eosinófilos, hemácias e basófilos (Figura 7B).

Células sanguíneas maduras e imaturas formavam um parênquima relativamente frouxo. Melano-macrófagos livres, melano-macrófagos centrais, vasos sanguíneos que continham em seu interior hemácias, células reticulares, pequenos linfócitos, trombócitos e sinusoídes estavam presentes dispersos pelo parênquima. A presença de túbulos contorcidos distais e proximais em uma determinada região do órgão foi observada e este fato pode ter sido ocasionado por se tratar da zona de transição entre o rim e o rim cefálico, não se confirmando a presença de tais estruturas no restante das áreas analisadas (Figura 8). Porém, a grande maioria do órgão era constituído por hemácias (Figura 9).

Ultraestruturalmente os túbulos contorcidos proximais encontrados na região que seria de transição do rim e do rim cefálico eram constituídos por células arredondadas alongadas com prolongamentos da membrana no ápice da célula. Apresentavam um núcleo de formato irregular com heterocromatina condensada periférica e um nucléolo excêntrico. No seu citoplasma numerosos grânulos, mitocôndrias arredondadas e alongadas e vacúolos foram observadas. Estas células estavam conectadas entre si por desmossomos e entre uma e outra célula havia a presença de uma célula limitante (Figura10).

As células que foram encontradas para análise ultraestrutural foram eosinófilos, protombócito, trombócitos, mielócitos, linfócitos, células tronco, neutrófilo, monócitos-macrofagos e linfócitos. (Figura 11). 
Eosinófilos nesta espécie se mostraram como células grandes de formato arredondado com núcleo grande de margem irregular, apresentando cromatina heterogênea condensada próxima a membrana com um nucléolo pequeno excêntrico. Disperso no seu citoplasma muitos grânulos de formato arredondado , alguns vacúolos e mitocôndrias foram observados (Figura 12).

Protrombócitos imaturos e protrombócitos são células com núcleo grande em forma de ferradura com cromatina heterogênea condensada próxima a parede da membrana. Seu citoplasma mostrava numerosos vacúolos, reticulo endoplasmático e grânulos (Figura 13).

Os mielócitos apresentaram um formato arredondado com núcleo grande periférico, com cromatina condensada na periferia e dispersas pelo núcleo. No seu citoplasma muitos vacúolos, mitocôndrias, retículo endoplasmático rugoso, vesículas com material no seu interior e um complexo de Golgi foram observados dispersos no citoplasma. Estas células, na sua maioria, estavam próximas às células eosinófilas (Figura 14).

Os linfócitos são pequenos, com pouco citoplasma onde se observou a presença de algumas mitocôndrias, raros vacúolos e material granular disperso homogeneamente. Continha um núcleo grande e arredondado. Este núcleo ocupava quase toda área da célula e continha muita cromática condensada que se distribuía irregularmente por todo núcleo. (Figura 15).

As células tronco apresentaram um formato arredondado irregular com pequenas projeções na sua membrana. Esta célula mostrava um núcleo grande com reentrâncias formando um " $\mathrm{H}$ ", tinha pouca cromatina e um nucléolo central. Dispersos em seu citoplasma foram encontrados retículos endoplasmáticos, mitocôndrias arredondadas, vesículas contendo material em seu interior, vacúolos, ribossomos livres e alguns grânulos (Figura 16).

Monócitos não tinham uma forma definida e foram vistos em formato arredondado alongado ou de formato irregular, com pequenas projeções na membrana citoplasmática. Seu núcleo era grande e mostrava uma reentrância bem visível com material granular condensado heterogeneamente na periferia e disperso por ele. No citoplasma foi encontrado complexo de Golgi bem desenvolvido, grânulos, vesículas com material em seu interior, mitocôndrias arredondadas e alongadas e vacúolos (Figura 17). 
Foram observadas plasmócitos no parênquima entre eosinófilos e linfócitos. Estas células tinham um formato arredondado ovóide, núcleo grande central com heterocromatina condensada na periferia. No seu citoplasma uma quantidade muito alta de retículo endiplasmático rugoso caracterizava este tipo celular, Algumas mitocôndrias, vesículas contendo material no seu interior, grânulos e material eletron denso estavam presentes no seu citoplasma (Figura 18). 

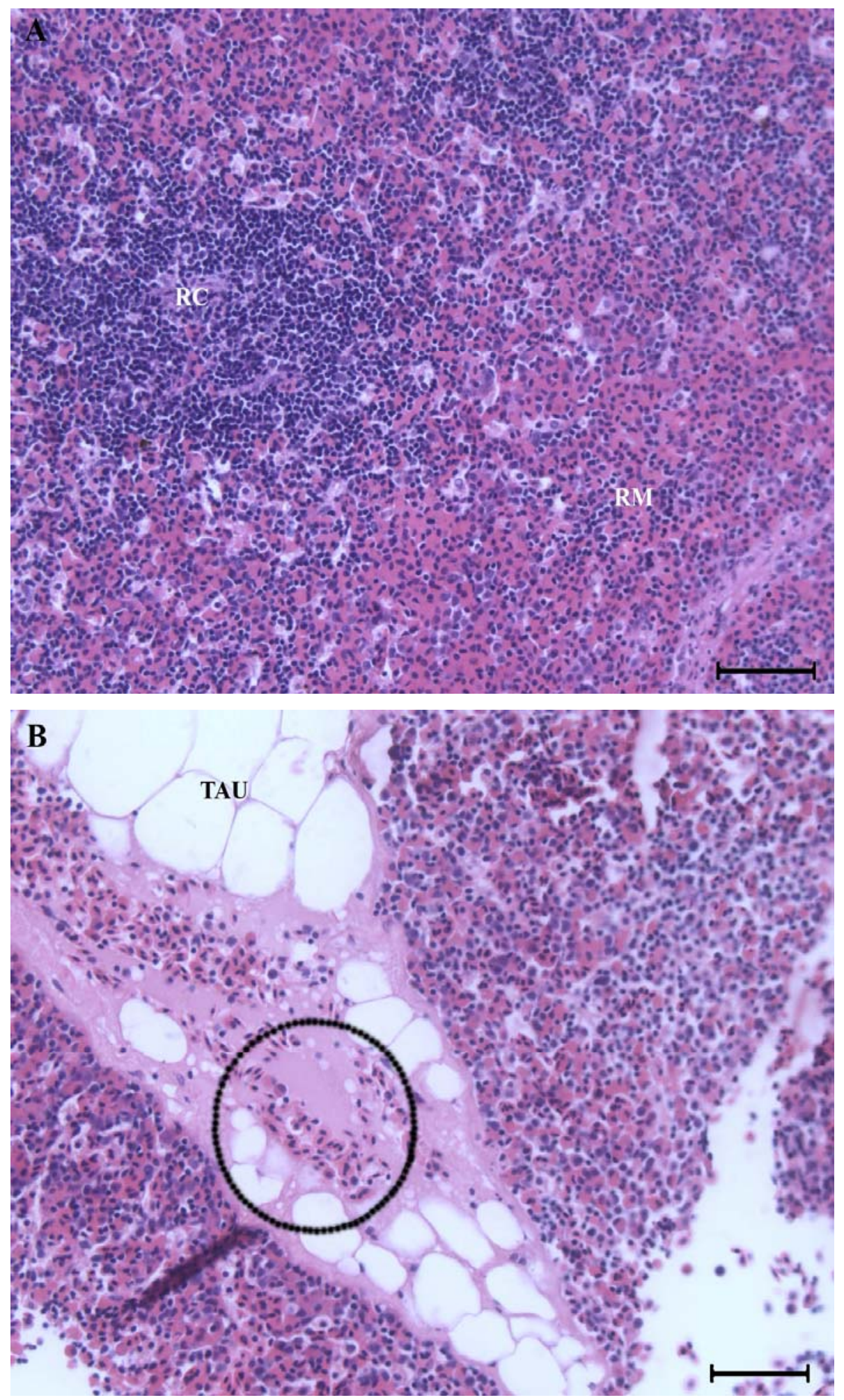

Figura 7- Fotomicrografia A: região medular do rim cefálico (RM) e

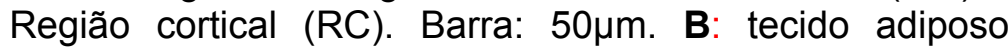
unilocular (TAU) e hemácias (circulo pontilhado). Coloração HE. Barra: $50 \mu m$ 


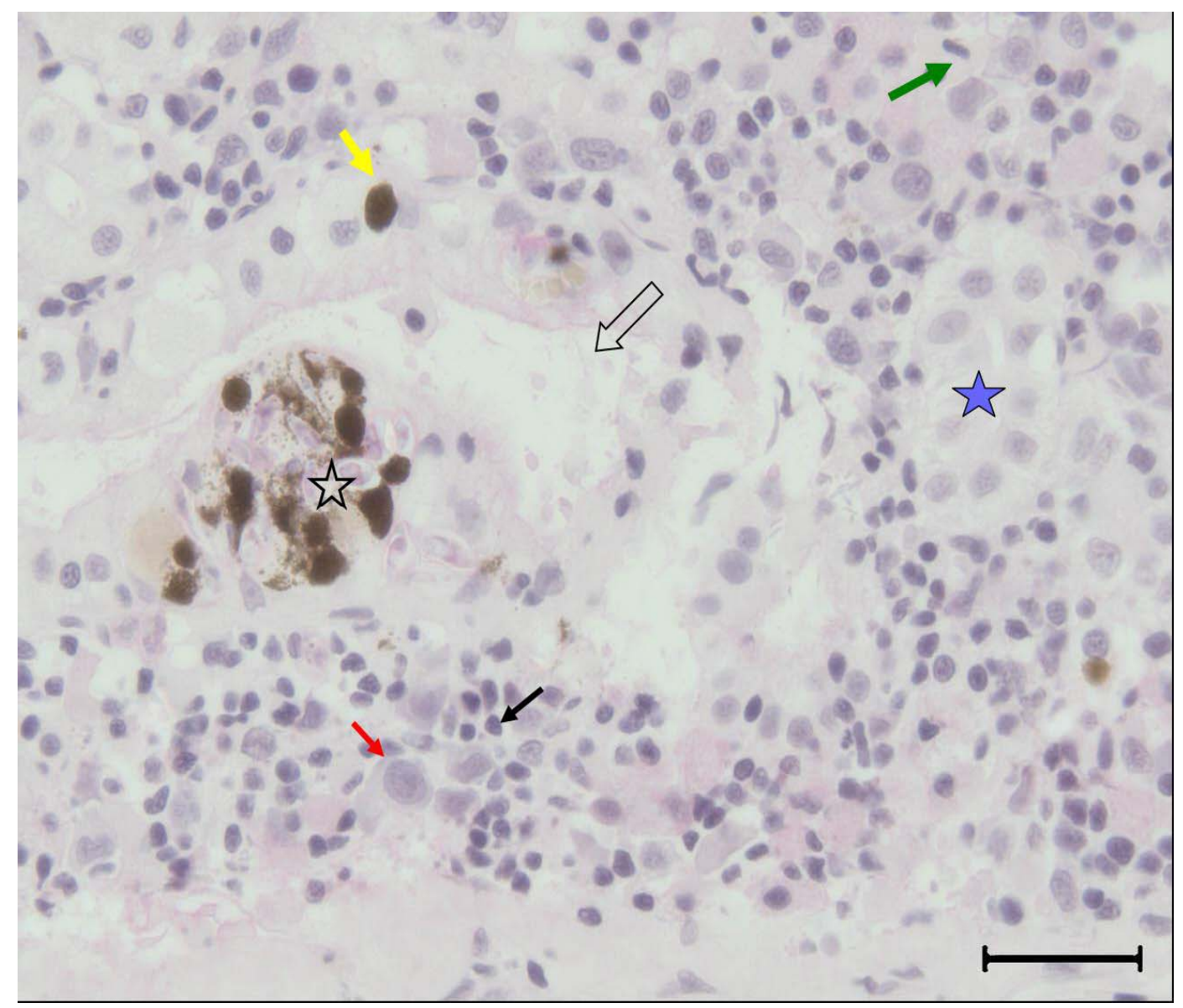

Figura 8 - Fotomicrografia do rim cefálico. Observar no vaso sangüíneo (seta vazia) hemácias; túbulos contorcidos proximais (estrela azul); linfócitos (seta preta); célula reticular (seta vermelha); trombócitos (seta verde); melano-macrófagos livres (seta amarela) e melanomacrófagos centrais (estrela vazia) Observar o parênquima constituído em sua maioria por células sangüíneas relativamente

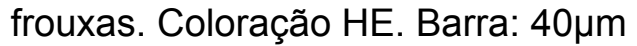




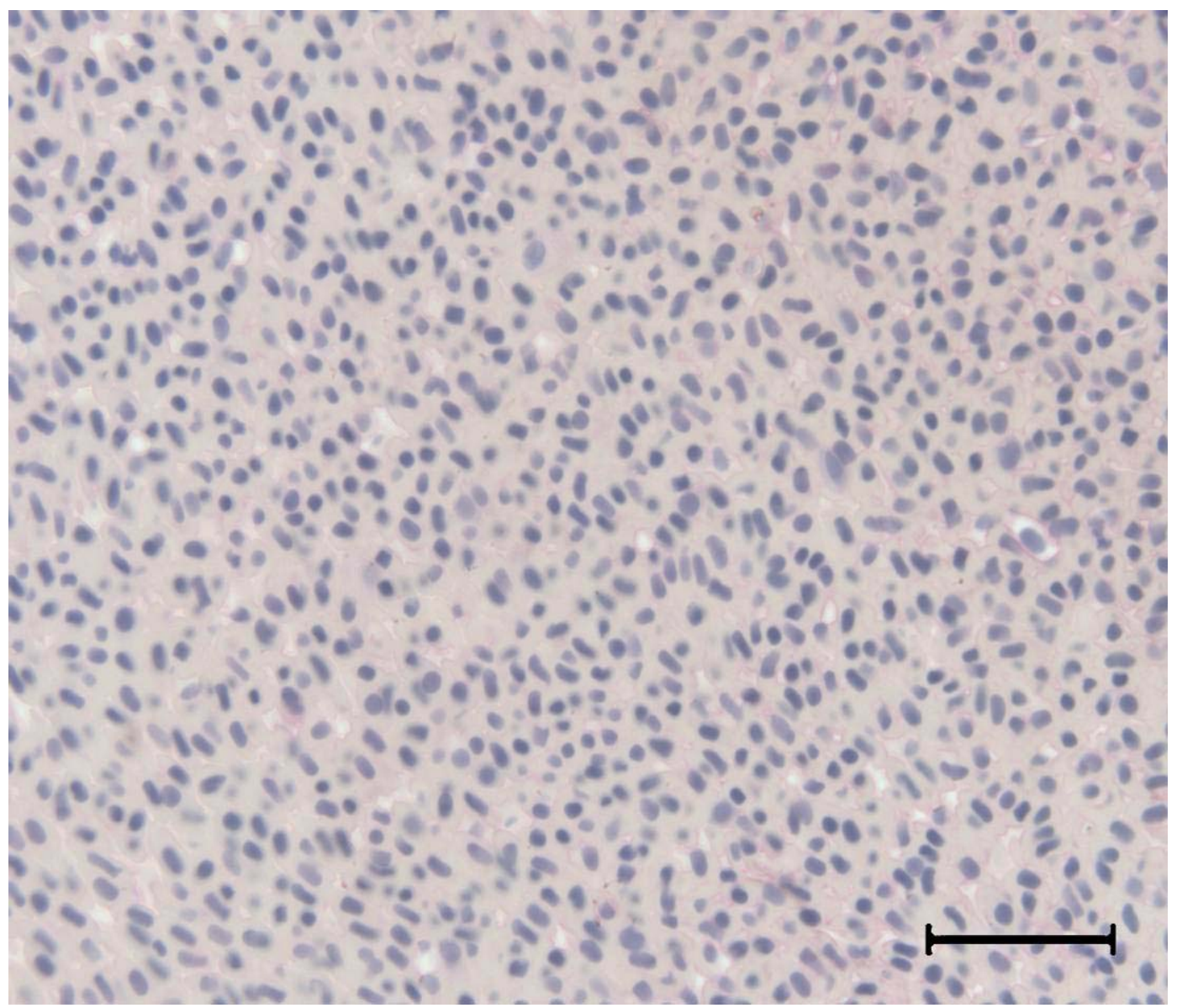

Figura 9 - Fotomicrografia do rim cefálico: Parênquima constituído na sua maioria por hemácias. Observar que a região cortical e medular são pouco distintas. Coloração HE. Barra: $40 \mu \mathrm{m}$ 


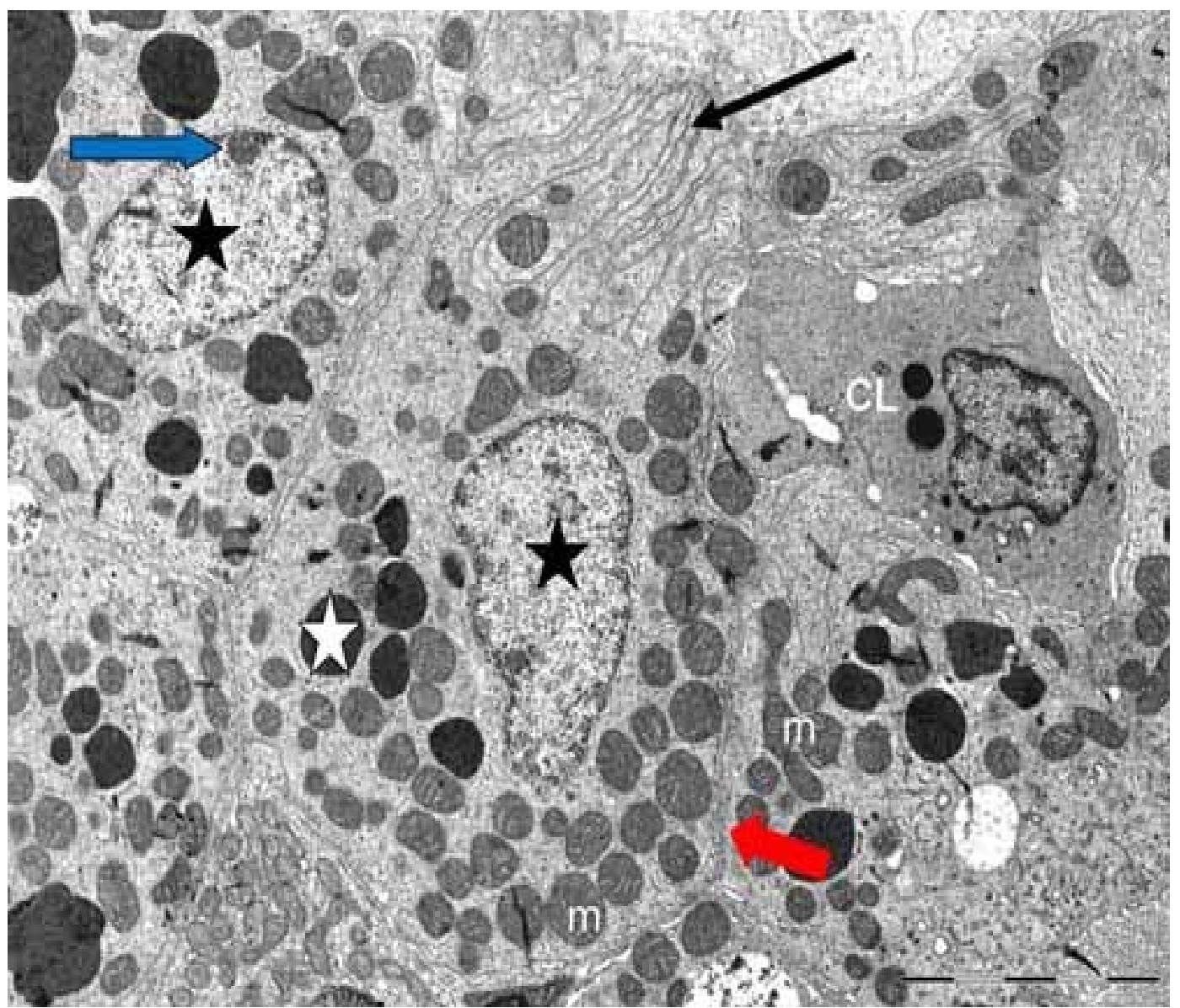

Figura 10 - Eletromicrografia do túbulo contorcido proximal em área de transição entre rim e rim cefálico. $\mathrm{Na}$ célula endotelial microvilosidades apicais (seta fina), um núcleo de formato irregular (estrela preta) com heterocromatina e eucromatina (seta azul), vacúolos eletro-densos (estrela branca) e muitas mitocôndrias (m). Desmossomos interconectavam essas células (seta vermelha) e entre uma célula e outra pôde-se observar uma célula limitante $(C L)$ Barra: $5 \mu \mathrm{m}$ 


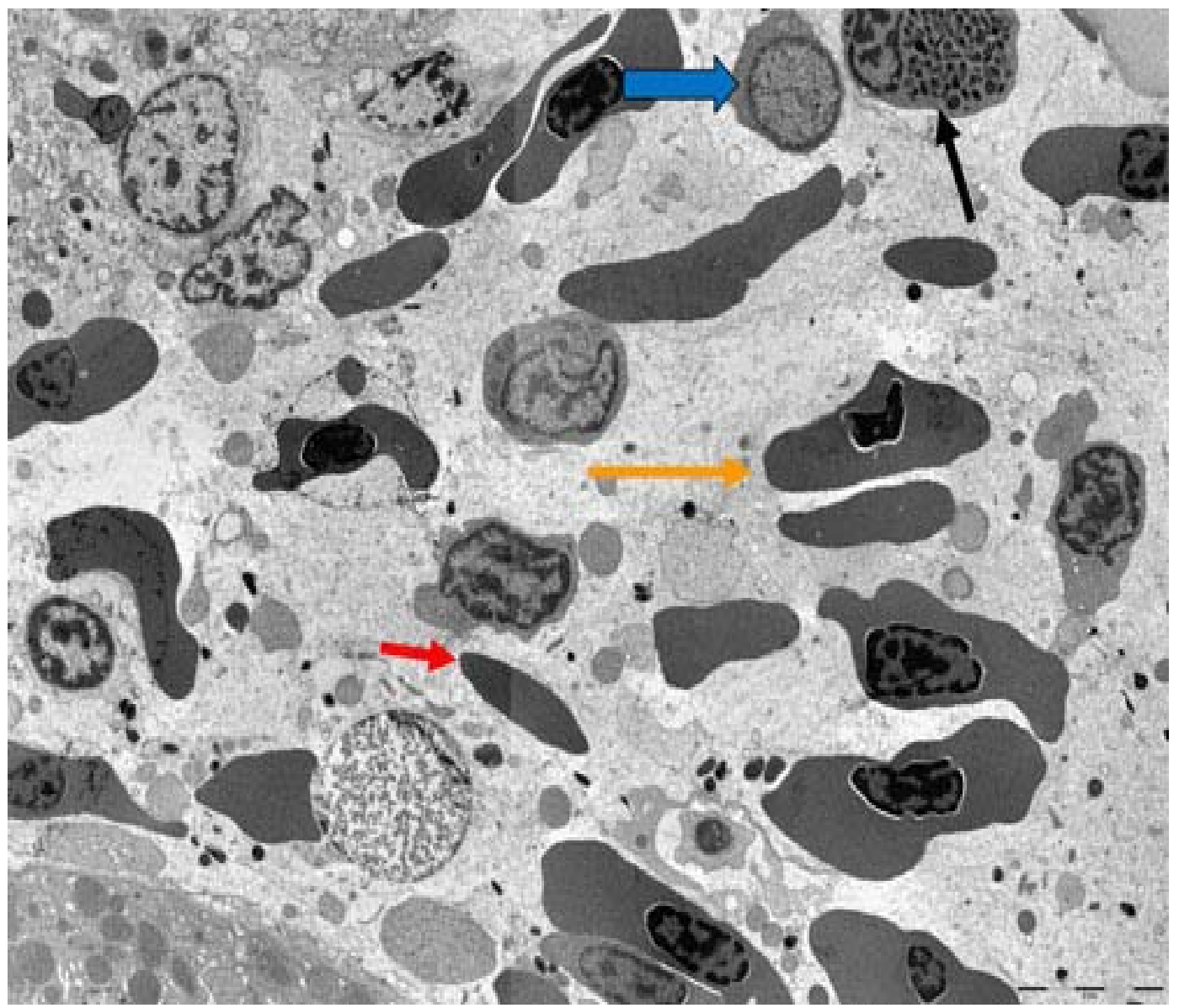

Figura 11 - Eletromicrografia do parênquima do rim cefálico. Observar hemácias (seta laranja); trombócitos (seta vermelha); linfócitos (seta azul) e eosinófilos (seta preta) Barra de $5 \mu \mathrm{m}$ 


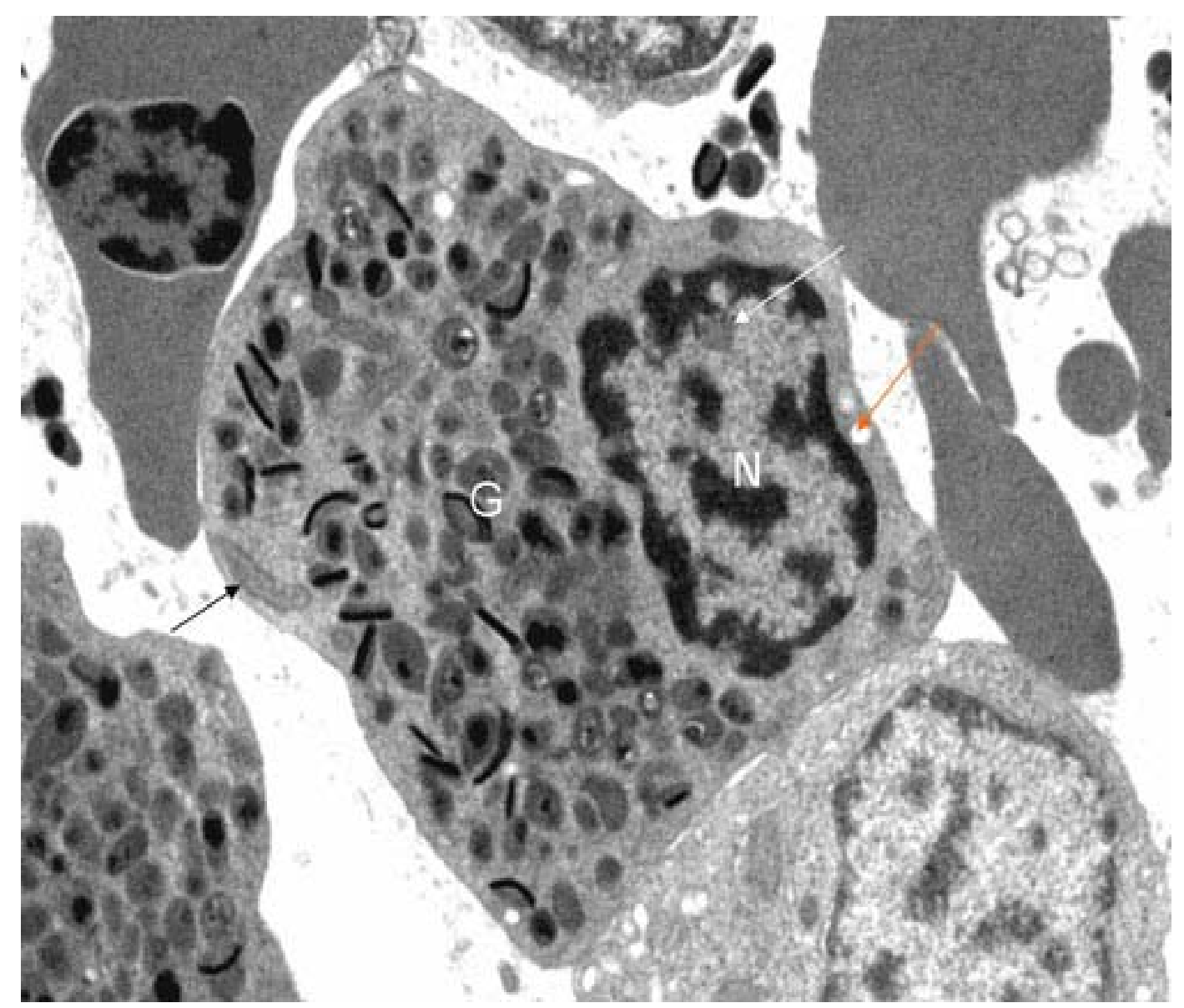

Figura 12 - Eletromicrogafia de eosinófilo do rim cefálico. Observar a forma irregular da célula. Núcleo grande eucromático $(\mathbf{N})$ e um nucléolo evidente (seta branca fina). No citoplasma presença de grânulos (G), mitocôndria (seta pequena) e vacúolos (seta vermelha), Barra $5 \mu \mathrm{m}$ 


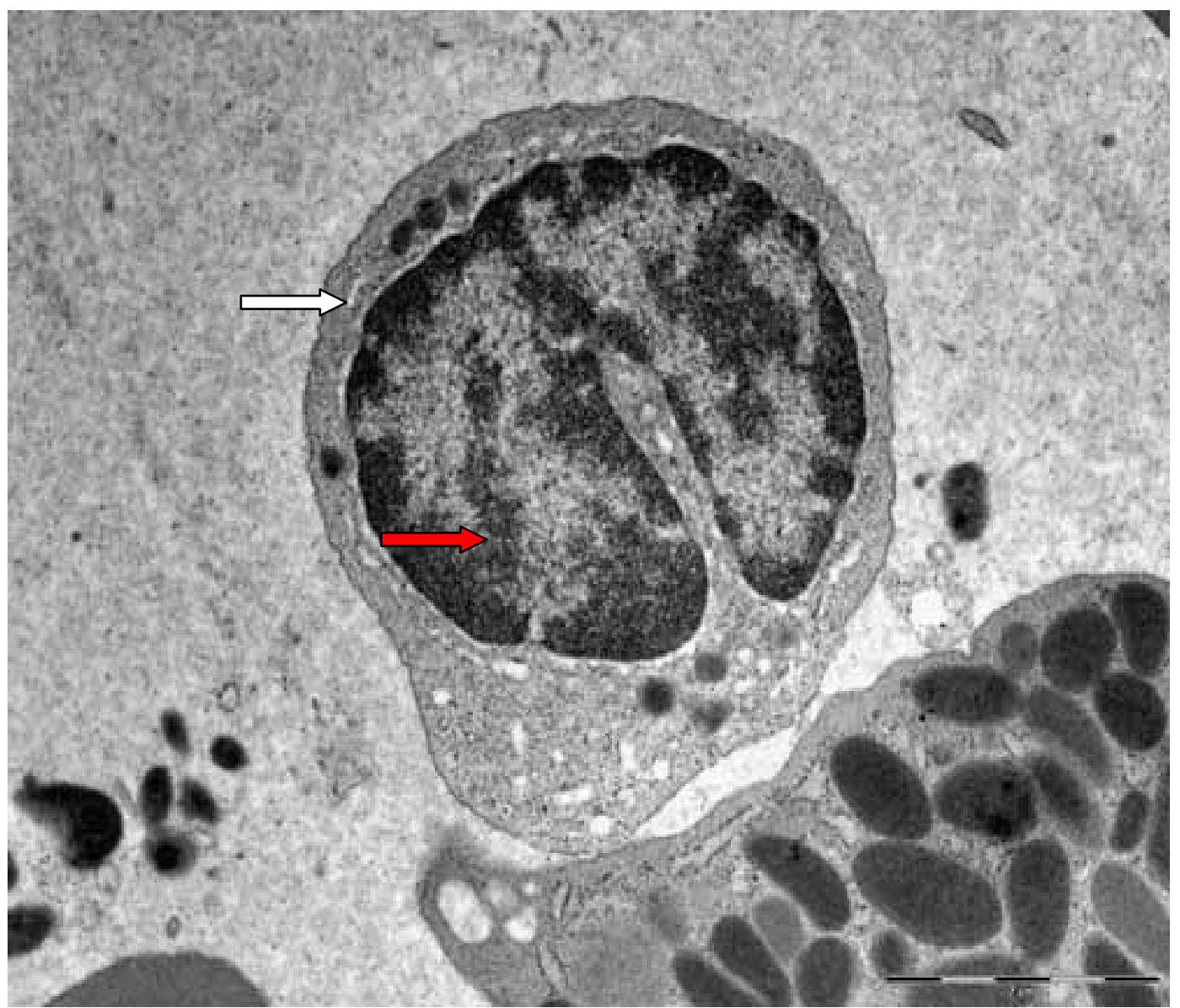

Figura 13 - Eletromicrografia de protrombócito encontrado no rim cefálico. Esta célula apresentava um formato arredondado, núcleo eucromático grande em forma de ferradura (seta branca), vacúolos (seta vermelha). Barra: $2 \mu \mathrm{m}$ 


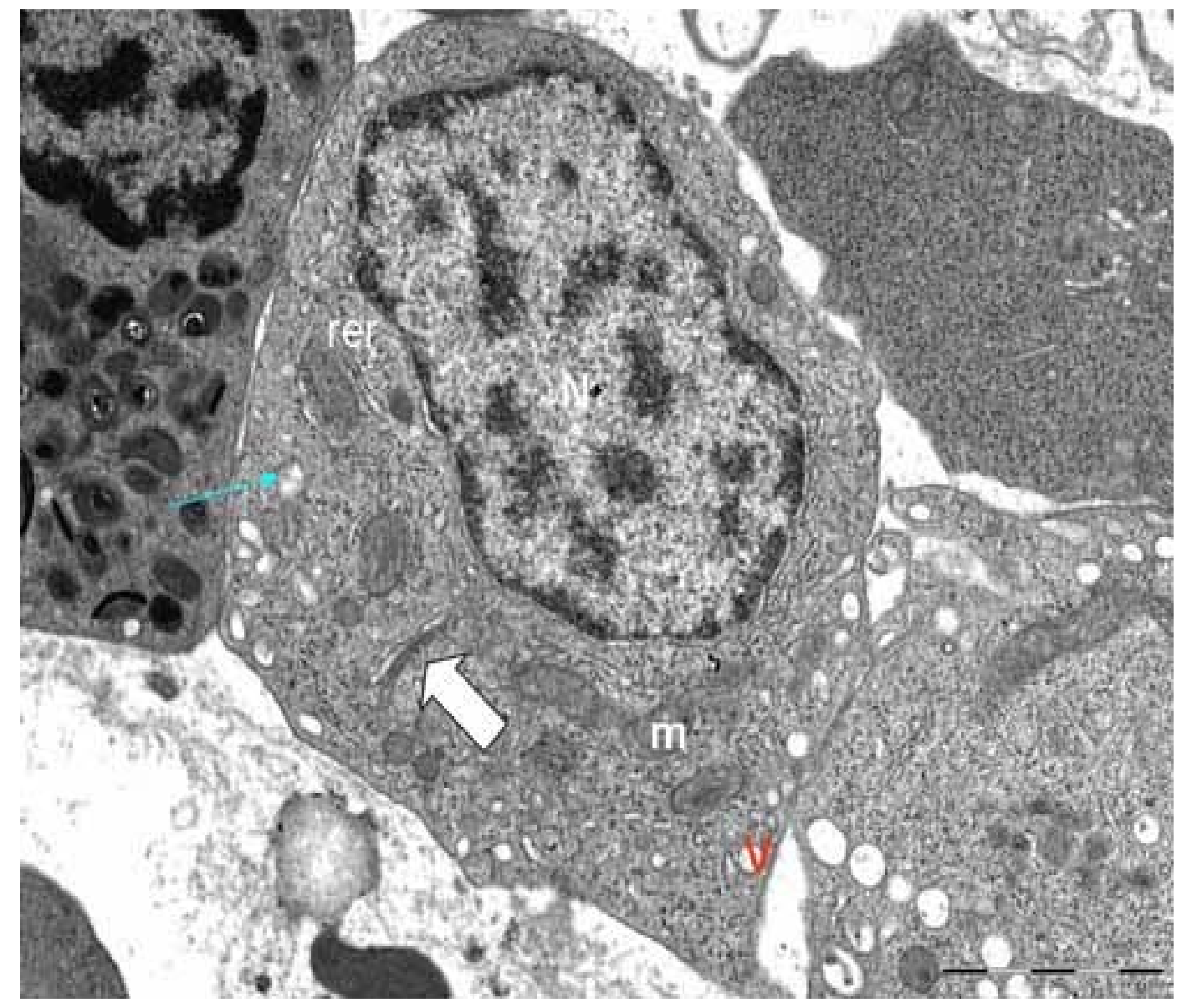

Figura 14- Eletromicrografia de mielócito. Observar o núcleo grande, excêntrico com eucromatina $(\mathrm{N})$. No citoplasma, presença de vacúolos $(\mathrm{V})$, vesículas (seta azul), retículo endoplasmático rugoso (rer), mitocôndrias (m) e complexo de Golgi (seta larga). Barra de $2 \mu \mathrm{m}$ 


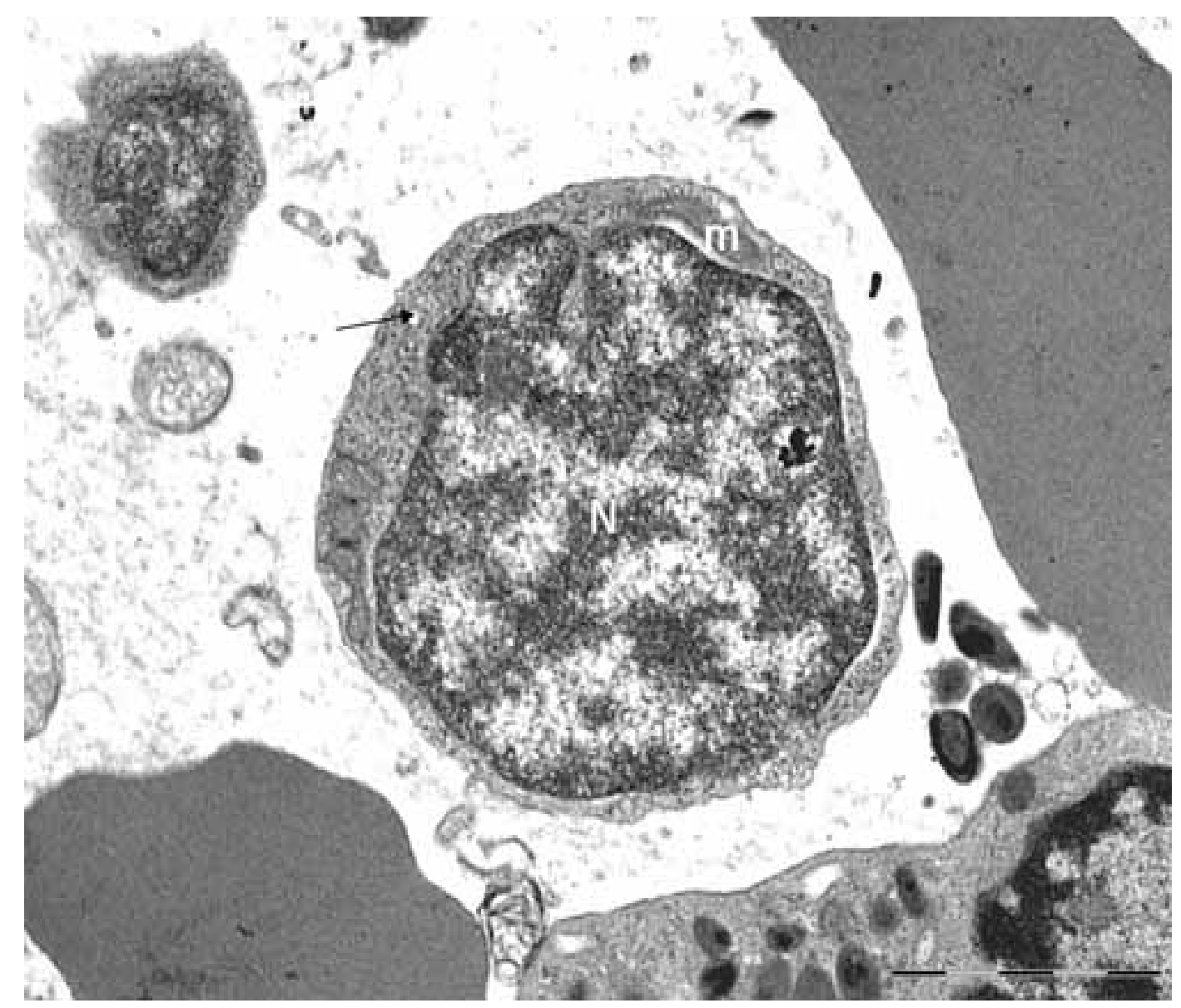

Figura 15 - Eletromicrografia de linfócito no rim cefálico. Observar um núcleo grande $(\mathrm{N})$ com muita eucromatina. No citoplasma mitocôndrias $(\mathrm{m})$, alguns vacúolos (seta pequena) e material granular. Barra de $2 \mu \mathrm{m}$. 


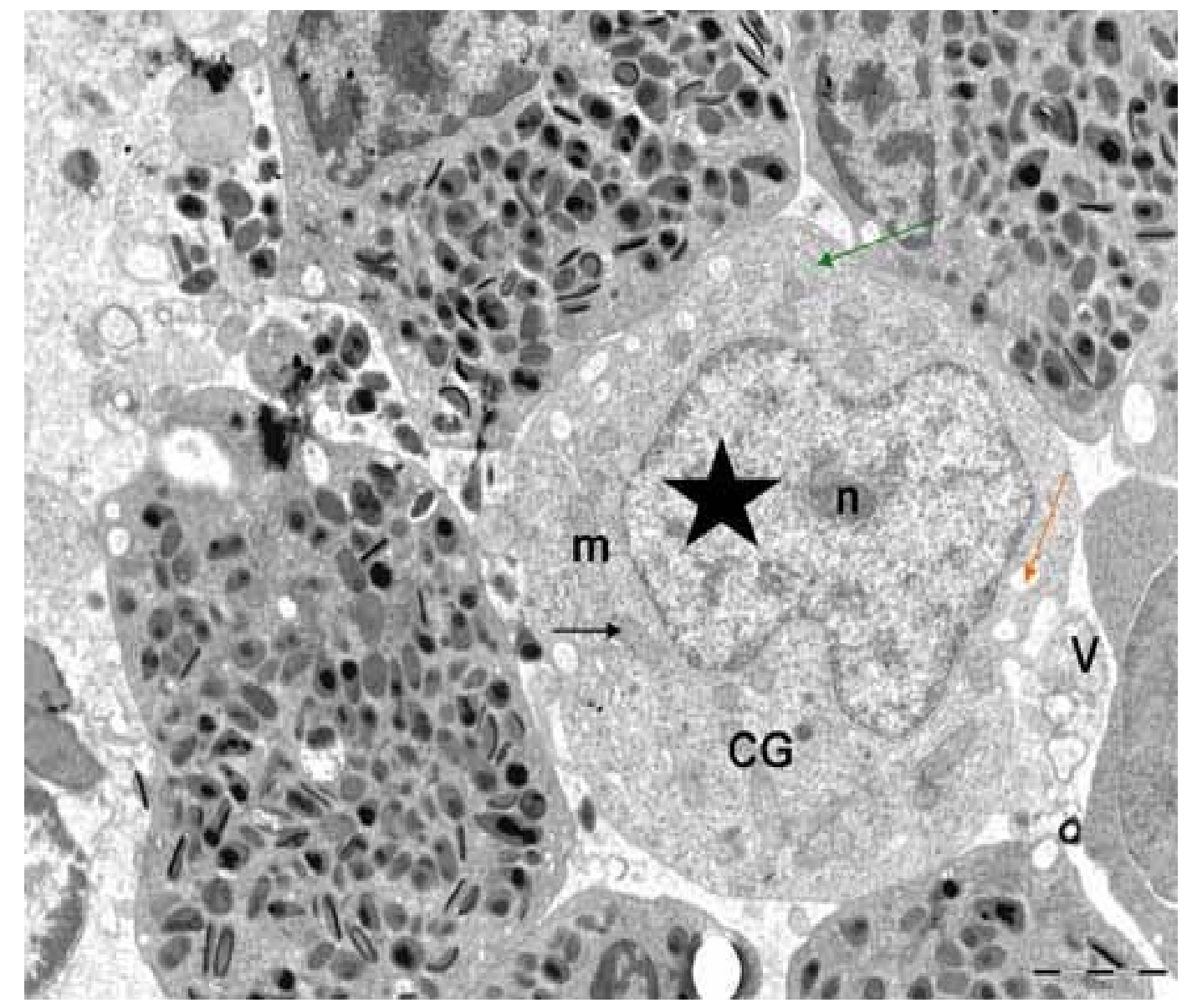

Figura 16 - Eletromicrografia de uma célula tronco no rim cefálico. Observar a o formato arredondado da célula com pequenas projeções da membrana. Seu núcleo grande com reentrâncias (estrela) e um nucléolo central ( $n$ ). No citoplasma complexo de Golgi (CG), vesículas $(\mathrm{V})$, vacúolos (seta vermelha), retículo endoplasmático (seta pequena) mitocôndrias $(\mathrm{m})$ e ribossomos livres (seta verde). Barra de $2 \mu \mathrm{m}$ 


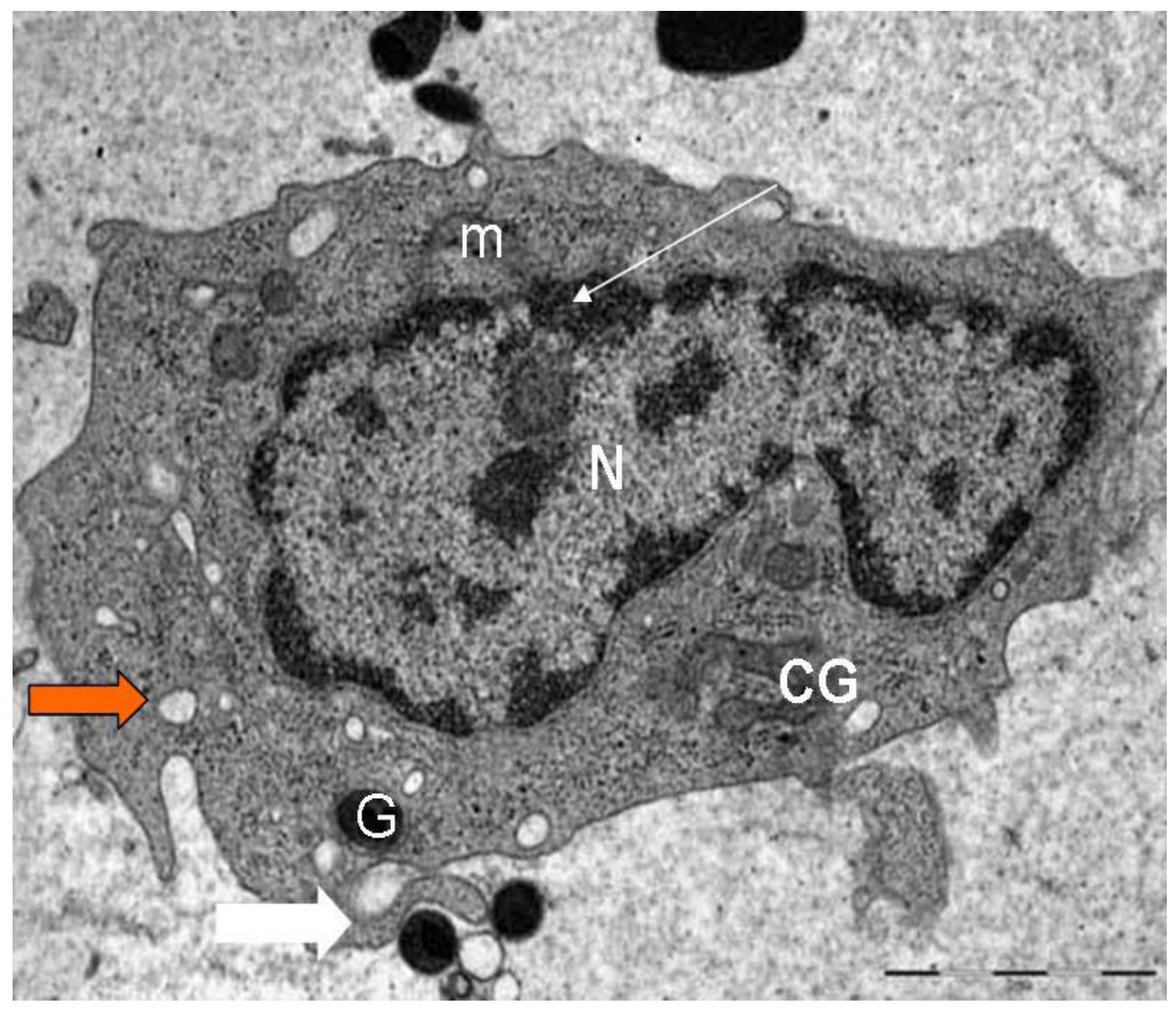

Figura 17 - Eletromicrografia de monócito no rim cefálico. Observar a forma irregular da célula com projeções citoplasmáticas (seta larga branca), núcleo grande $(\mathrm{N})$ com reentrâncias e heterocromatina e eucromatina (seta branca). No citoplasma presença de complexo de Golgi (CG), grânulos (G), vesículas (seta vermelha), mitocôndrias (m) e vacúolos (v). Barra de $2 \mu \mathrm{m}$ 


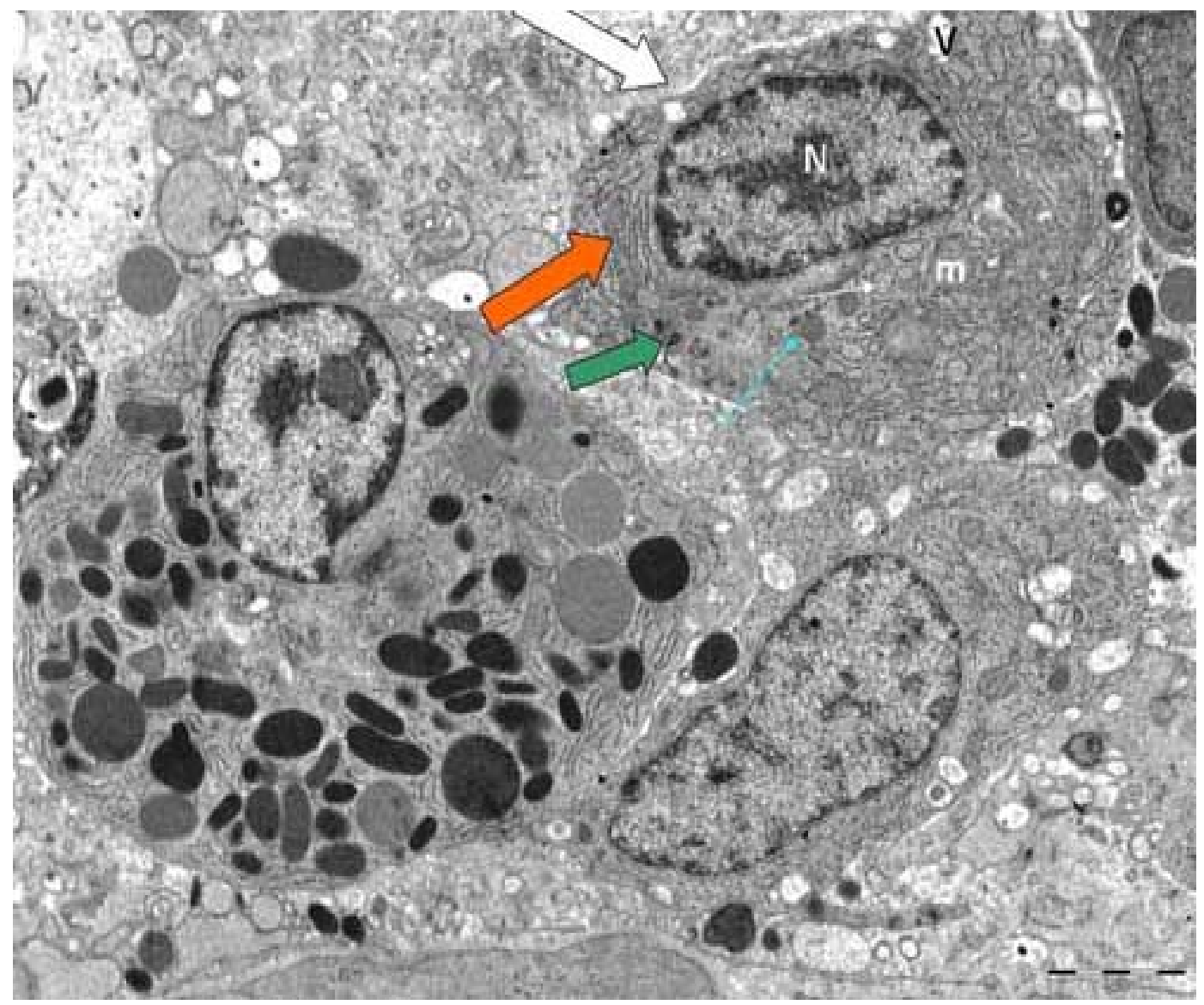

Figura 18 - Eletromicrografia de plasmócito no rim cefálico (seta larga). Célula caracterizada pela grande quantidade de reticulo endoplasmático rugoso em seu citoplasma (seta vermelha). Núcleo grande central com heterocromática na periferia $(\mathrm{N})$, algumas mitocôndrias $(\mathrm{m})$, vacúolos $(\mathrm{V})$, vesículas (seta azul) e material eletron denso (seta verde) disperso pelo seu citoplasma. Barra $2 \mu \mathrm{m}$ 


\subsubsection{Fígado}

O fígado é formado por hepatócitos de formato poliédrico constituindo a maior parte do parênquima. Apresentam um núcleo grande redondo central (Figura 19A).

O parênquima não é dividido em lóbulos e há formação do espaço porta, constituído por um ducto biliar, uma artéria e uma veia, envoltos por tecido conjuntivo (Figura 19A). Veias centrais associadas a ductos ou a outras veias e/ou pequenas artérias mostram-se dispersas aleatoriamente por todo o parênquima hepático (Figura 19B).

Este se apresenta como um campo contínuo de hepatócitos em forma de cordões. Esses cordões são constituídos por dois hepatócitos e entre cada dois se encontra um sinusoíde que se conecta a um vaso. A presença de várias veias centrais, vasos e sinusóides dispersos por todo o parênquima são observados. Células dendítricas ou células endoteliais são observadas no interstício, interconectando os hepatócitos. Pôde-se observar nos hepatócitos vacúolos onde possivelmente estaria armazenado gordura e gotas de coloração marrom claro que poderiam ser de ferritina (Figura 20).

Ultraestruturalmente os hepatócitos apresentaram um núcleo central grande arredondado com cromatina condensada na periferia e dispersa pelo núcleo (Figura 21). No seu citoplasma foi observado réticulo endoplasmático rugoso, grânulos, complexo de Golgi, mitocôndrias e vacúolos (Figura 22). 

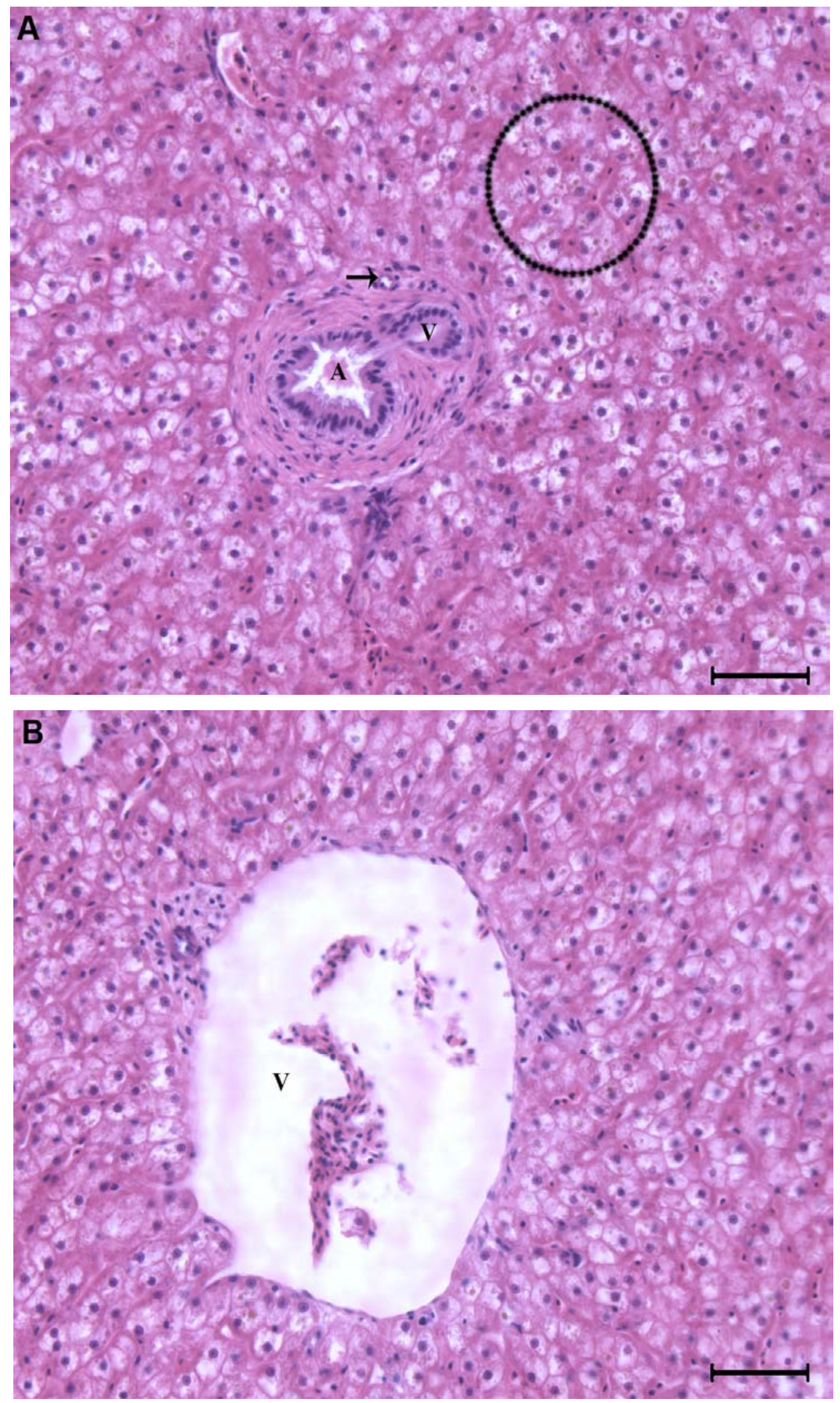

Figura 19 - Fotomicrografia A: Parênquima do fígado constituído por hepatócitos (círculo pontilhado), artéria hepática $(A)$, um ducto biliar (seta) e um ramo da artéria $(V)$. Barra: $50 \mu \mathrm{m}$ B: Veia central (V) associada a um ducto. Coloração HE. Barra: $50 \mu \mathrm{m}$ 


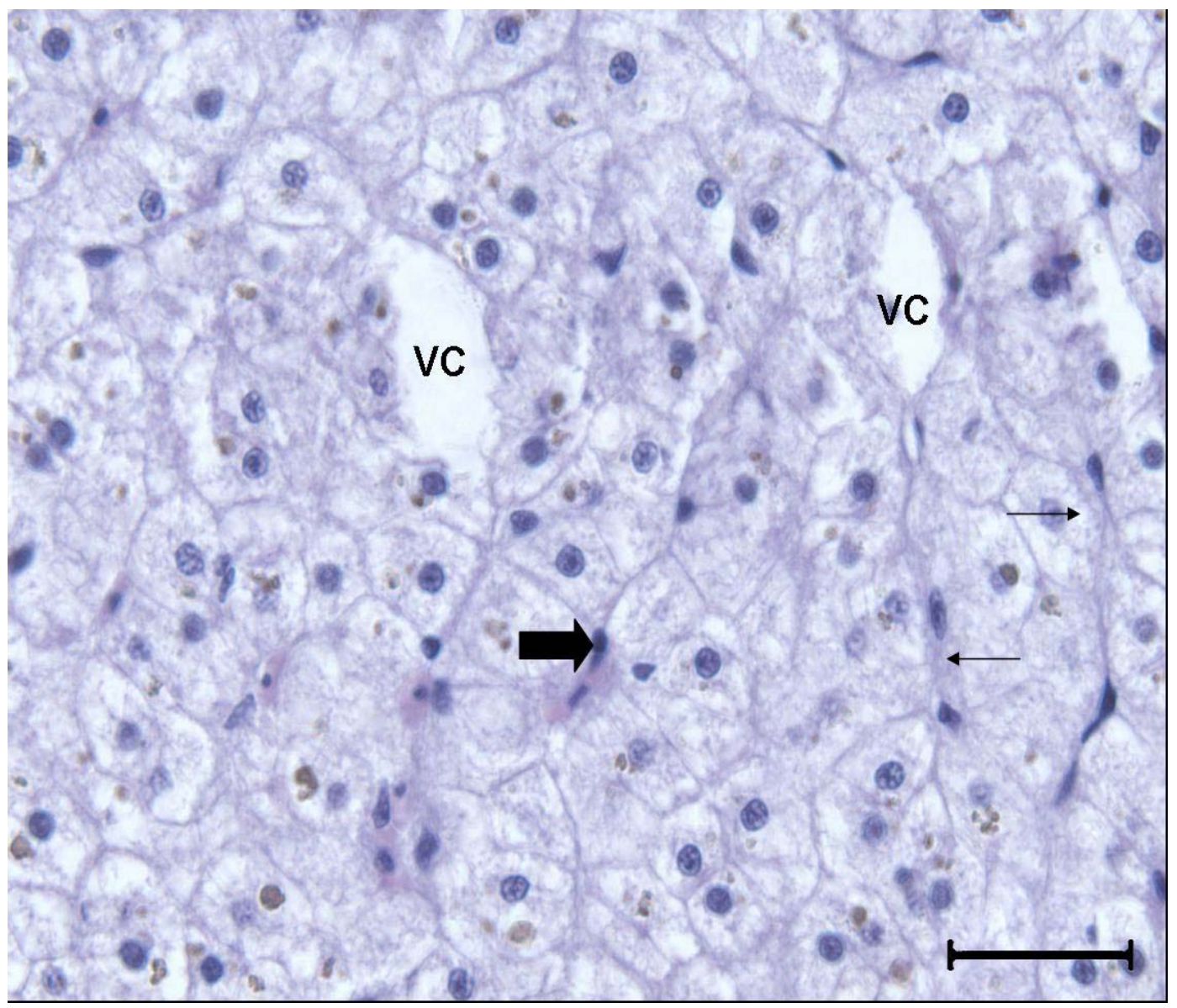

Figura 20 - Fotomicrografia do parênquima do fígado. Observar um parênquima formado por hepatócitos em forma de cordões e entre eles um pequeno vaso sinusóide (setas finas). Células dendriticas ou endoteliais (seta larga) aparecem entrem os hepatócitos. No interior dos hepatócitos observar a presença de gotículas amarronzadas e

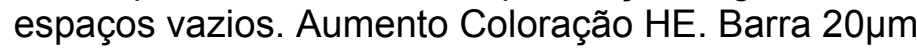




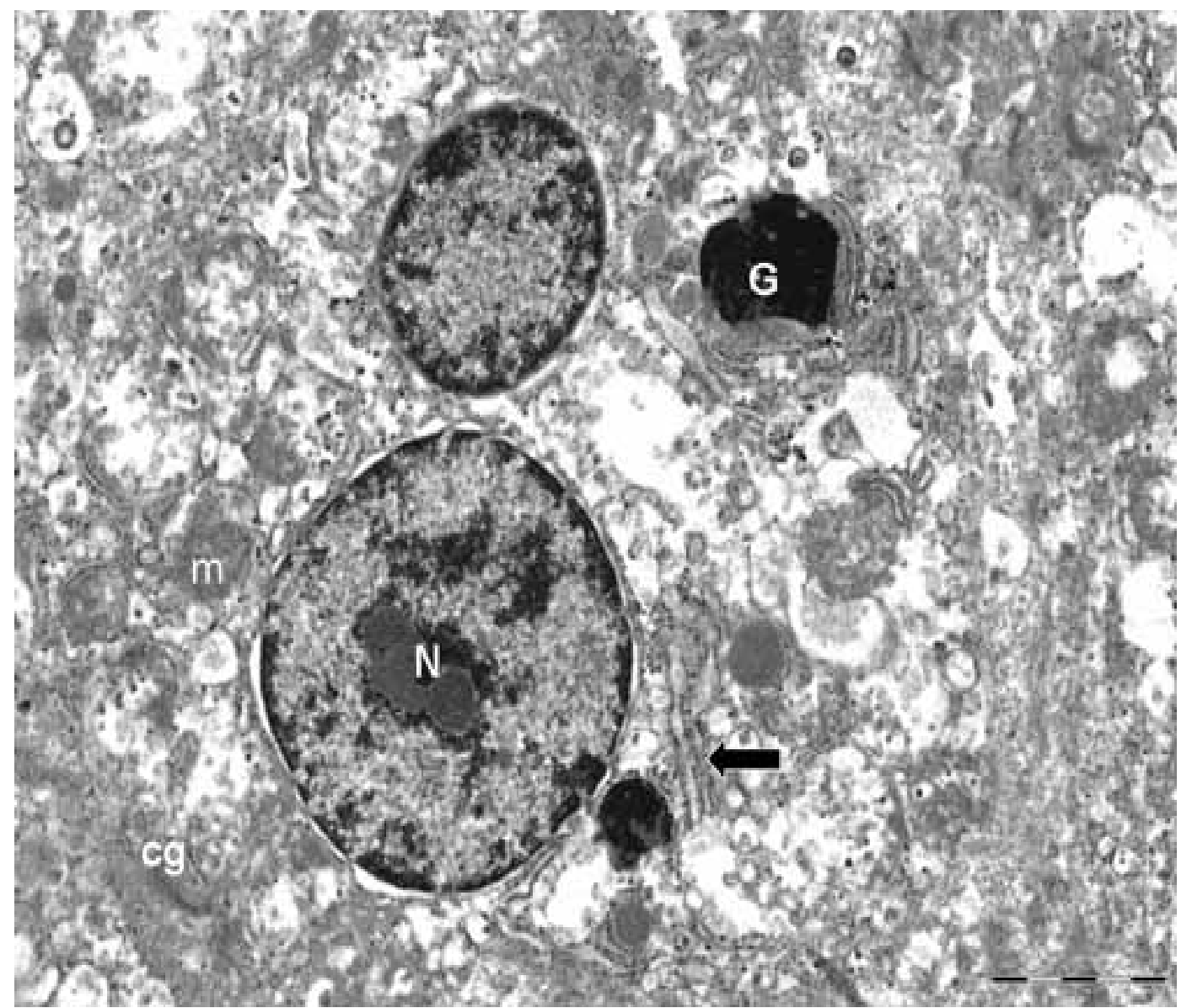

Figura 21 - Eletromicrografia do hepatócito. Esta célula apresentou um núcleo grande com cromatina condensada na periferia e dispersa pelo núcleo $(\mathrm{N})$. No citoplasma grânulos $(\mathrm{G})$, mitocôndrias $(\mathrm{m})$, complexo de Golgi (cg) e reticulo endoplasmático rugoso (seta). Barra $2 \mu \mathrm{m}$ 


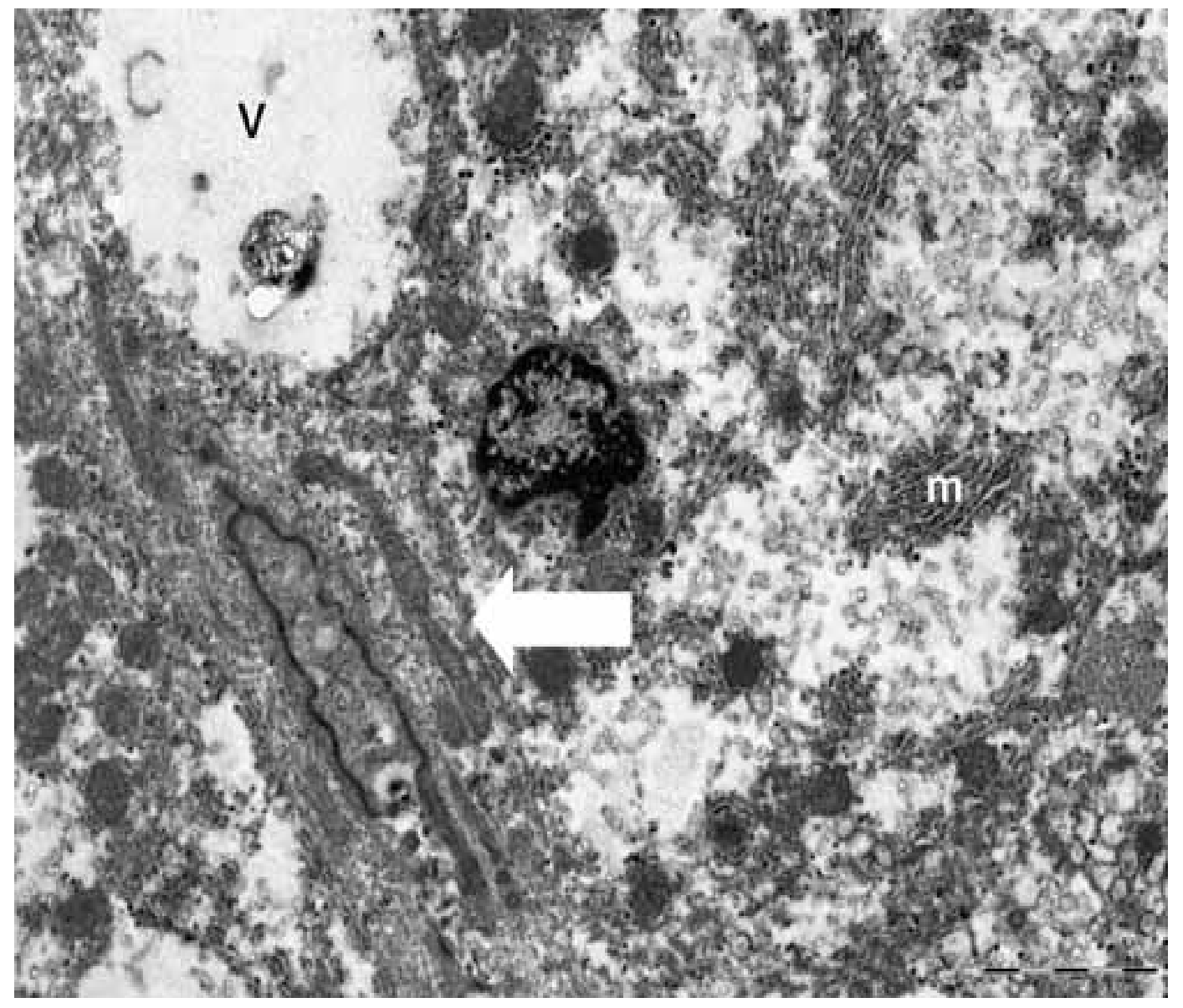

Figura 22 - Eletromicrografia de estruturas do hepatócito. Observar a presença de um complexo de Golgi (seta larga) bem desenvolvido, mitocôndrias $(\mathrm{m})$ e vacúolos $(\mathrm{V})$ onde poderia estar contido gordura. Barra $2 \mu \mathrm{m}$ 


\subsubsection{Timo}

O timo apresenta uma região de concentrados de timócitos formando os corpúsculos de Hassall (Figura 23A) sendo observadas no centro de alguns desses corpúsculos, células imaturas sofrendo divisão e nestes mesmos espaços, a presença de eosinófilos. Circundando os corpúsculos de Hassall, infiltrados mononucleares, provavelmente timócitos, são observados (Figura 23B).

Este órgão se mostrou bem vascularizado e próximo aos vasos infiltrados mononucleares, sendo também observado a presença de melano-macrófagos livres no parênquima (Figura 24).

O parênquima não apresentava uma zona medular e cortical distintas e constituindo o mesmo, foram observadas muitas hemácias, timócitos, alguns eosinofilos e células imaturas (Figura 25).

Nas análises ultraestruturais observamos no timo células tronco que apresentaram um formato irregular, núcleo grande com cromatina heterogênea, um nucléolo excêntrico e disperso no citoplasma mitocôndrias, complexo de Golgi e vacúolos (Figura 26).

Os eosinófilos apresentaram um formato irregular, núcleo excêntrico e grânulos dispersos em seu citoplasma (Figura 27).

Foram observadas trabéculas no interior do parênquima, constituídas por células epiteliais achadas que apresentavam um núcleo bem pequeno no ápice da célula. No seu interior pôde-se observar a presença de vaso sangüíneo. Disperso pelo parênquima fibras colágenas, células reticulares, grânulos e células limitantes se encontravam próximas a estas trabéculas (Figura 28).

Os timócitos se apresentaram como células pequenas de formas variadas. Seu núcleo era grande com heterocromatina condensada e seu citoplasma era curto e granulado. Em alguns casos mostrava extensões citoplasmáticas. Foram observados ribossomos livres, vacúolos e um pequeno complexo de Golgi no seu citoplasma (Figura 29). Foi encontrado geralmente conectado a uma célula limitante ou a uma célula "nurse cells". 
As células limitantes se caracterizaram por apresentar um núcleo grande, alongado e irregular que acompanhavam o formato da célula. Seu citoplasma emitia projeções que as interconectavam entre si e a outras células (Figura 30).

As "nurse-cells" apresentaram um núcleo grande, com reentrâncias, vacúolos, vesículas contendo material flocular e um pequeno complexo de Golgi (Figura 31). 

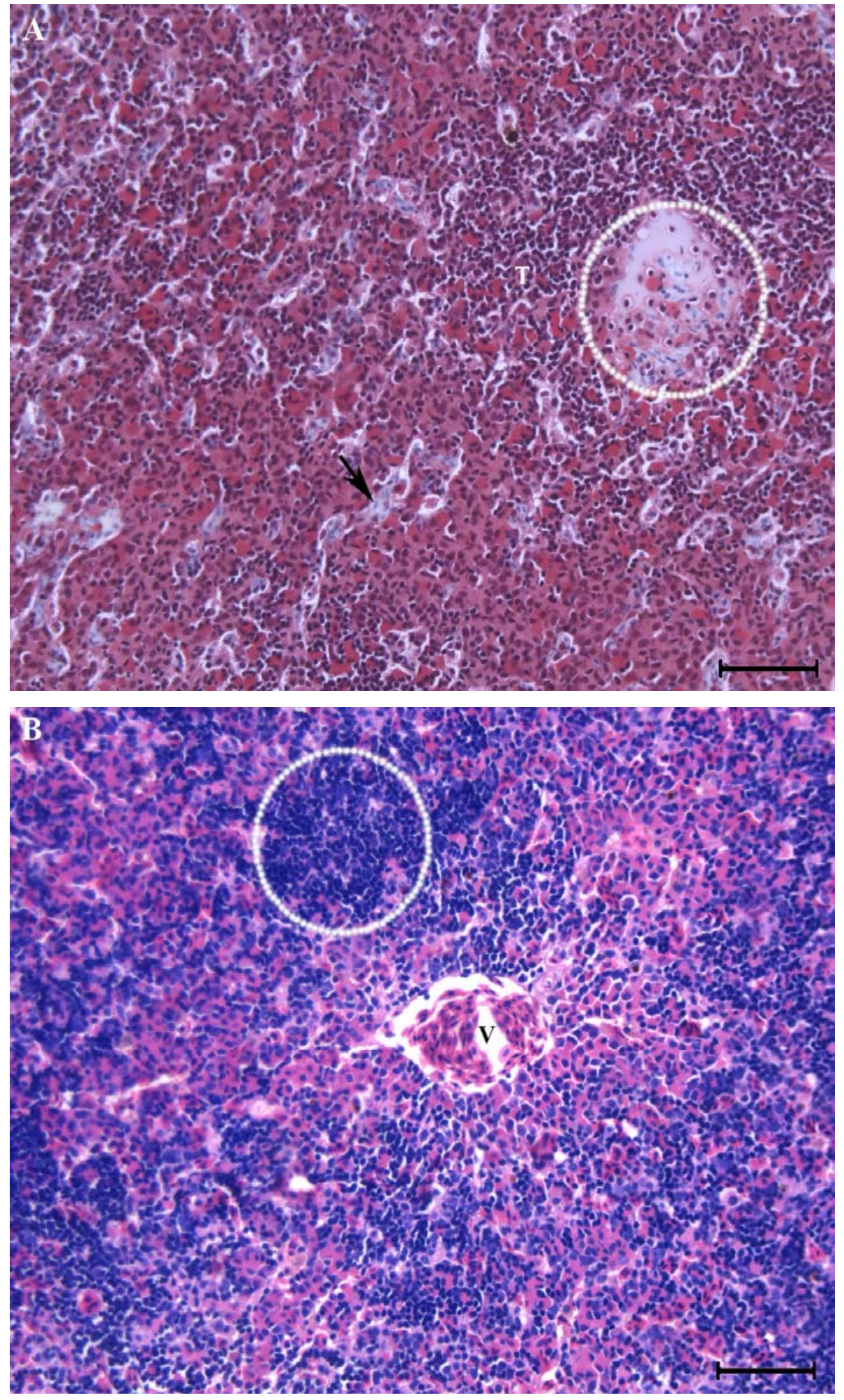

Figura 23 - Fotomicrografia. A: timo constituído pelo Corpúsculo de Hassall (circulo pontilhado), vasos sangüíneos (seta) Barra: $50 \mu \mathrm{m} \mathrm{B:}$ no tecido conjuntivo presença de vaso sangüíneo (V) e infiltrado mononuclear (circulo).

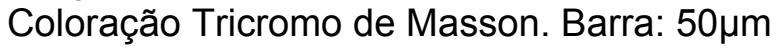




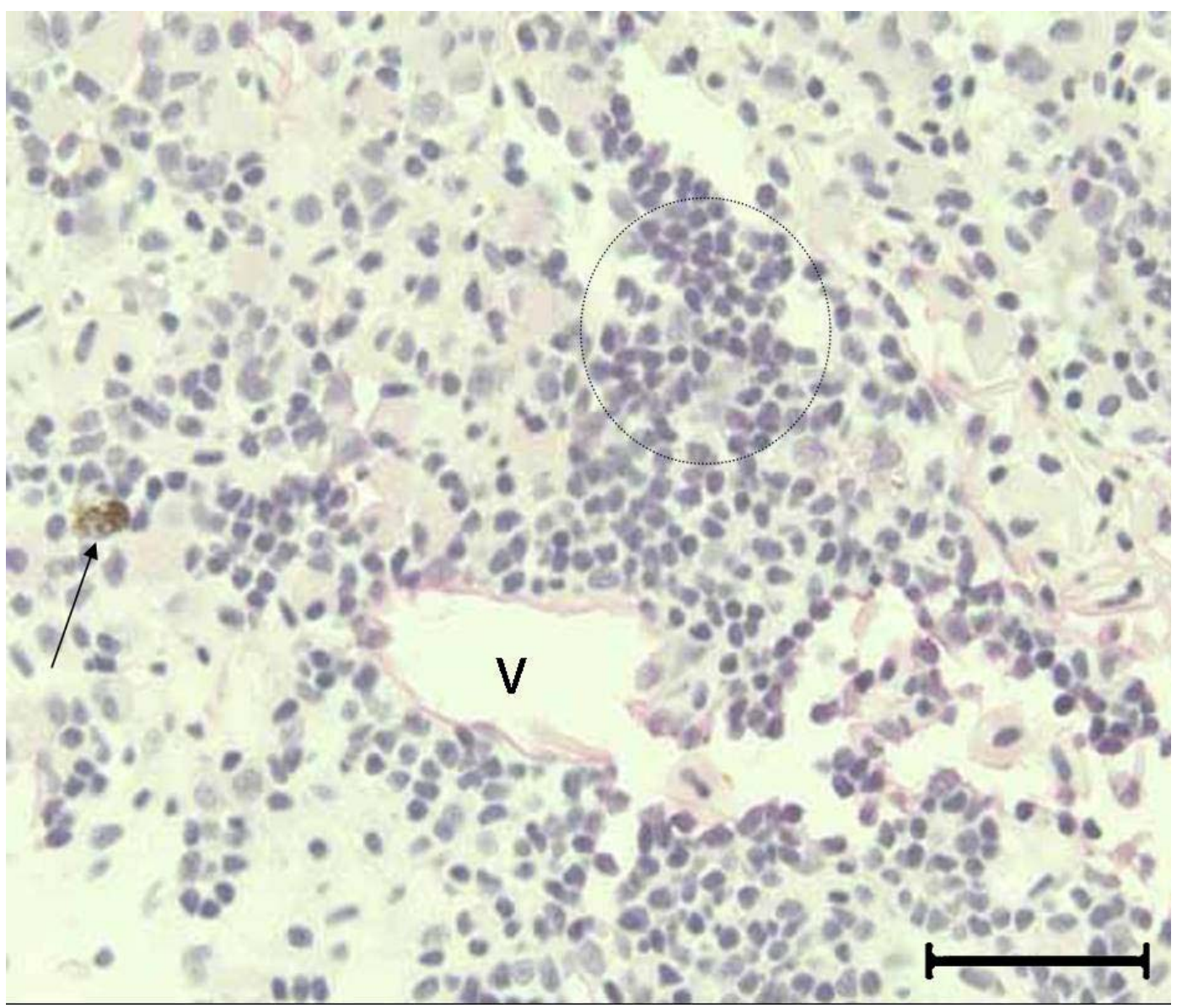

Figura 24 - Fotomigrafia de luz de parênquima tímico. Presença de muitos vasos sangüíneos contendo células sangüíneas maduras e imaturas (V), infiltrados mononucleares (circulo) e melanomacrófagos livres (seta). Coloração HE. Barra. $20 \mu \mathrm{m}$ 


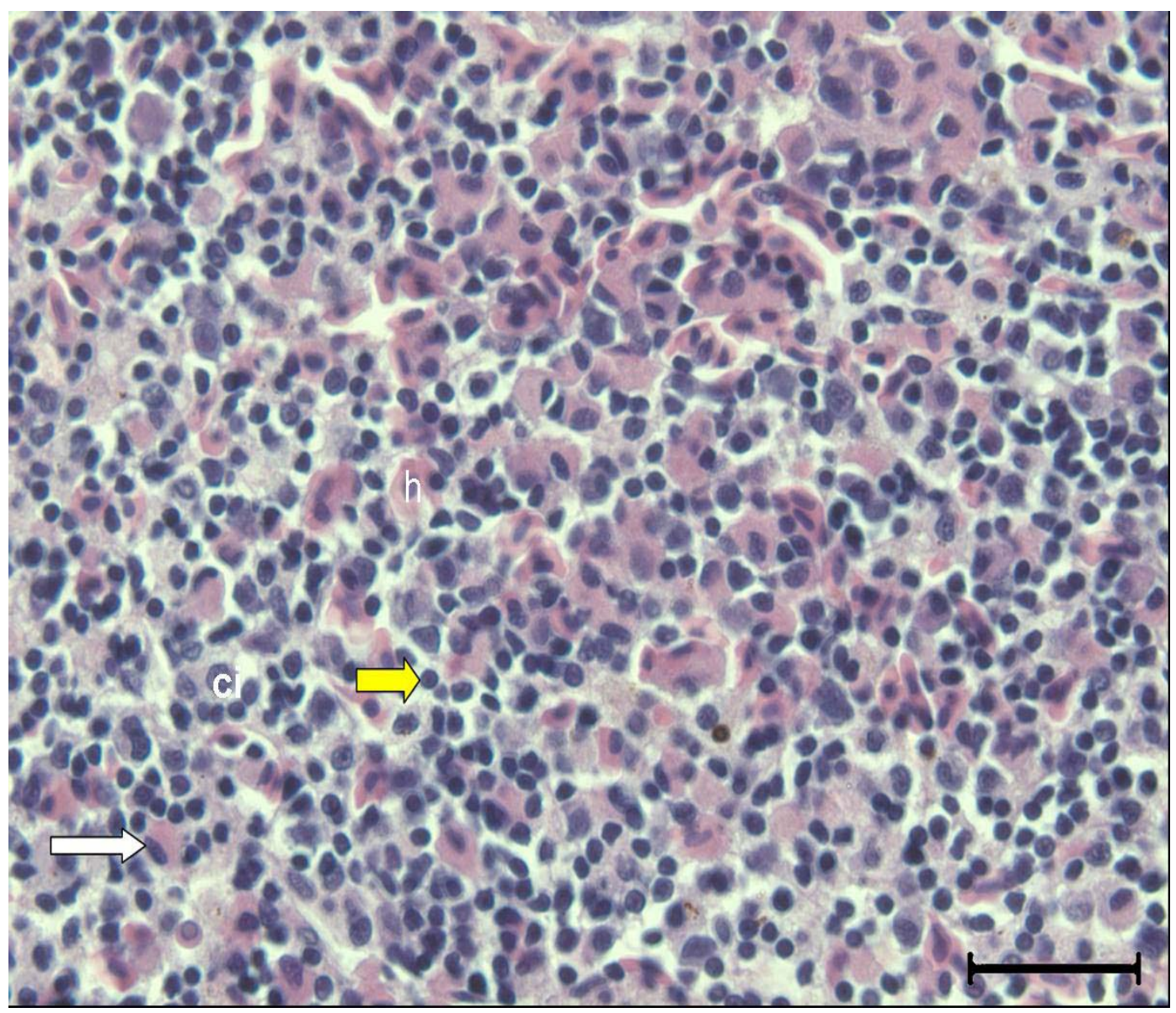

Figura 25 - Fotomicrografia de luz de parênquima tímico sem definição de zona cortical e medular. Parênquima constituído por hemácias (h), timócito (seta amarela), eosinófilo (seta branca) e células imaturas

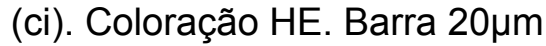




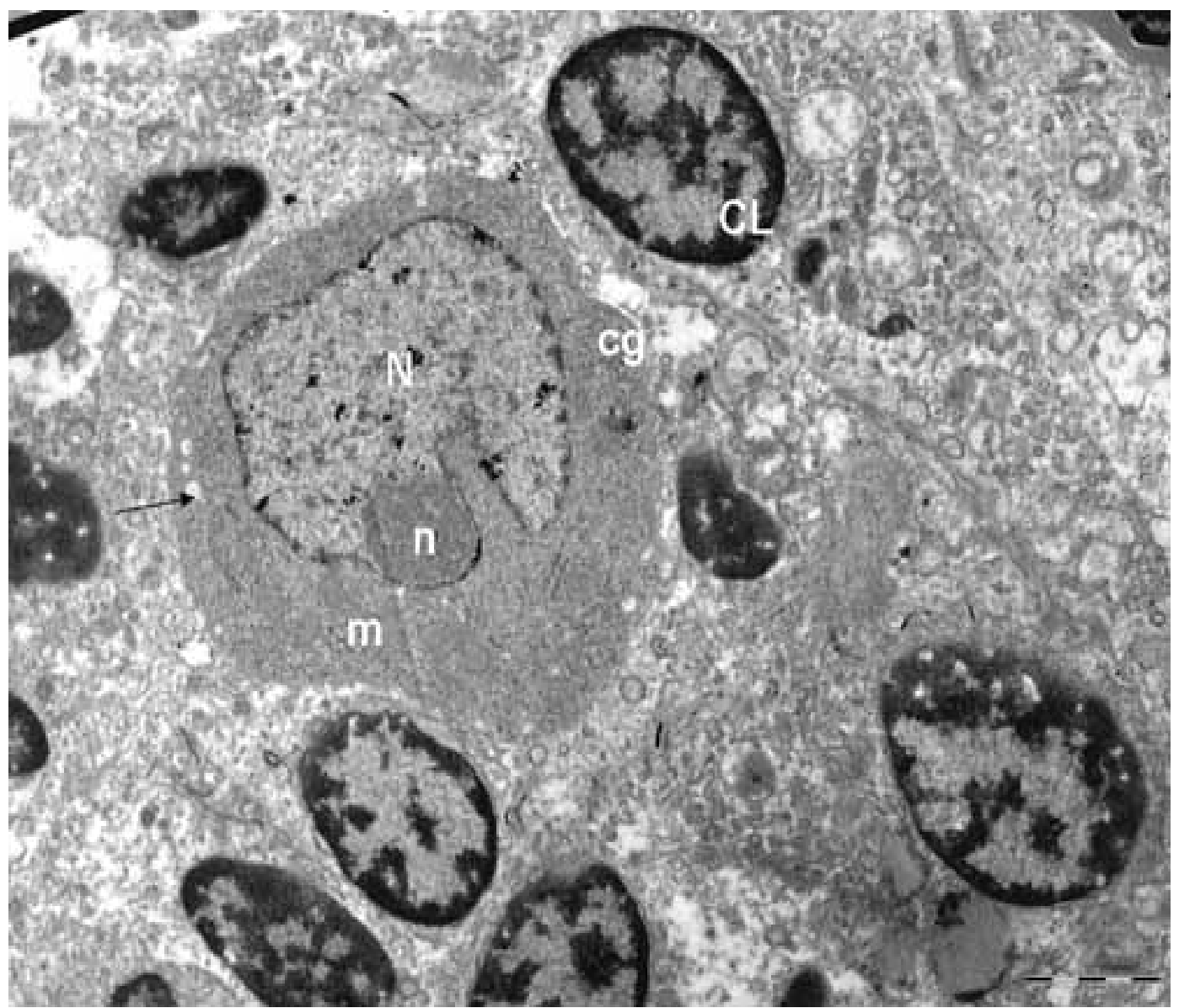

Figura 26 - Eletromicrografia de célula tronco do timo. Observar o formato irregular, com núcleo grande com cromatina heterogênea $(N)$, nucléolo excêntrico (n) e disperso no citoplasma mitocôndrias, Complexo de Golgi e vacúolos. Barra de $2 \mu \mathrm{m}$ 


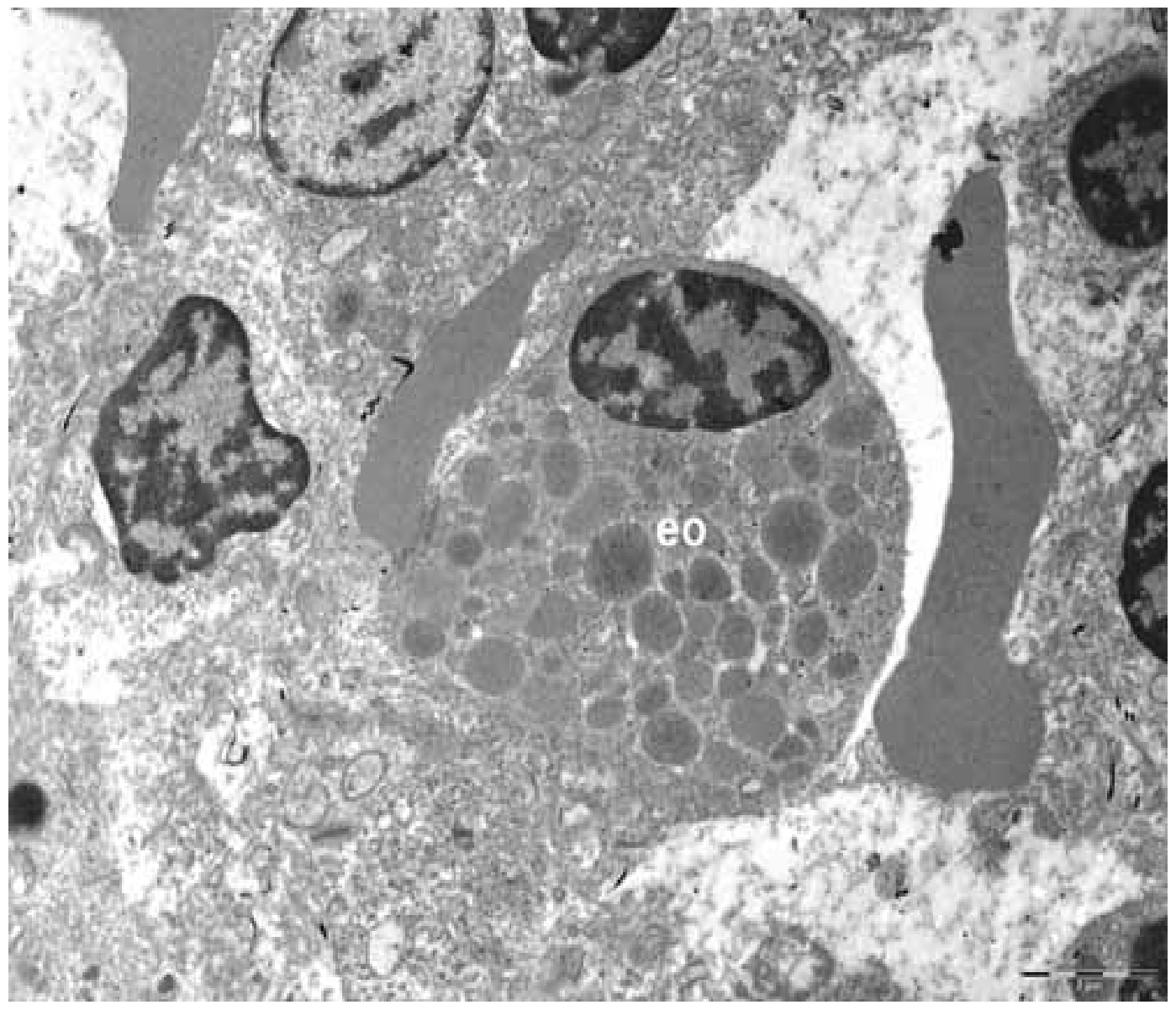

Figura 27 - Eletromicrografia de eosinófilo encontrado no timo de Piaractus mesopotamicus. Célula com formato irregular, núcleo excêntrico e grânulos dispersos em seu citoplasma. Barra de $2 \mu \mathrm{m}$ 


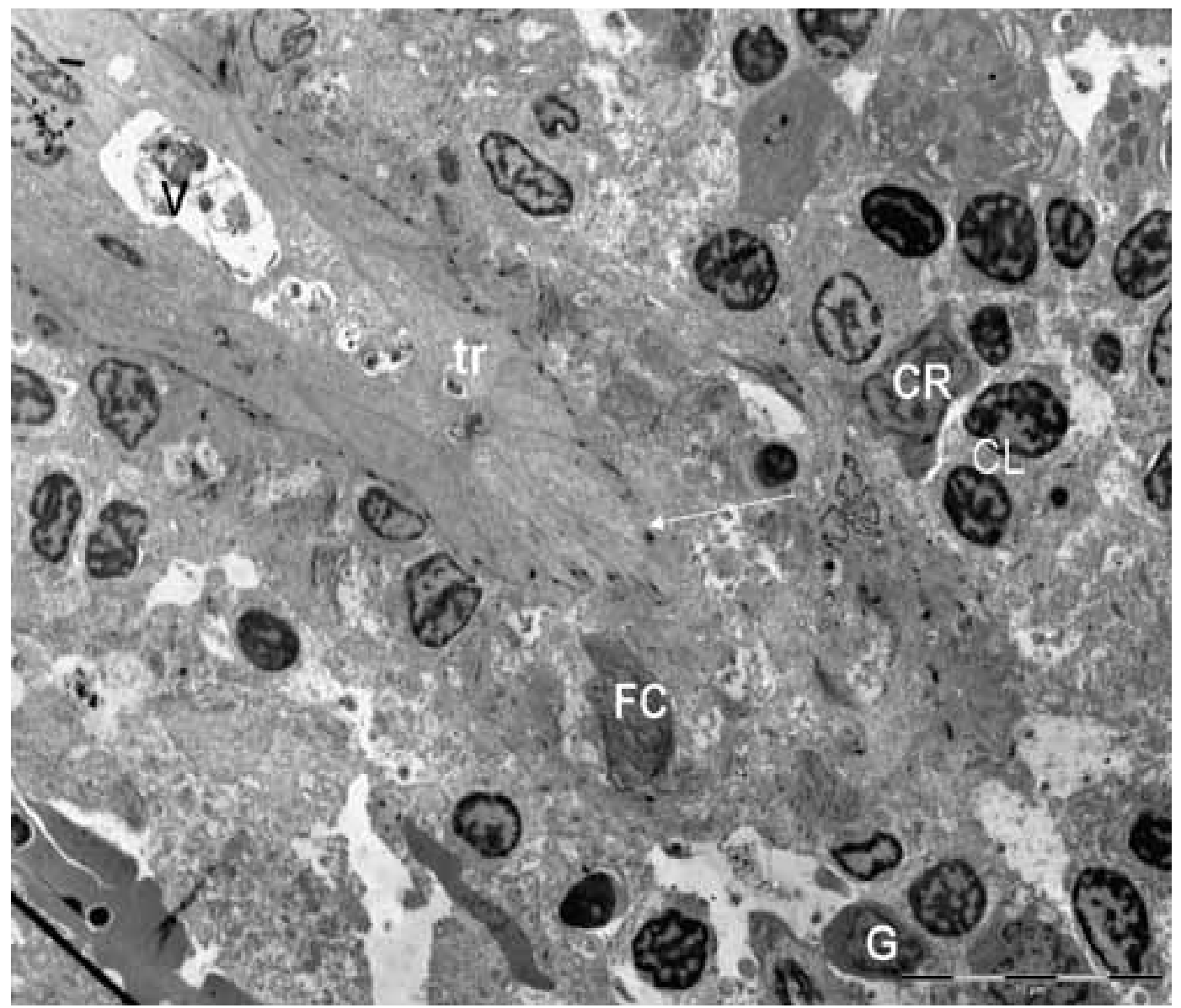

Figura 28 - Eletromicrografia de trabécula (tr) encontrada no timo. Constituída por células achatadas com núcleo pequeno no ápice celular (seta), vaso sangüíneo $(\mathrm{V})$, no parênquima fibras colágenos $(\mathrm{FC})$, células reticulares $(C R)$, células limitantes $(C L)$ e grânulos $(G)$. Barra de $10 \mu \mathrm{m}$ 


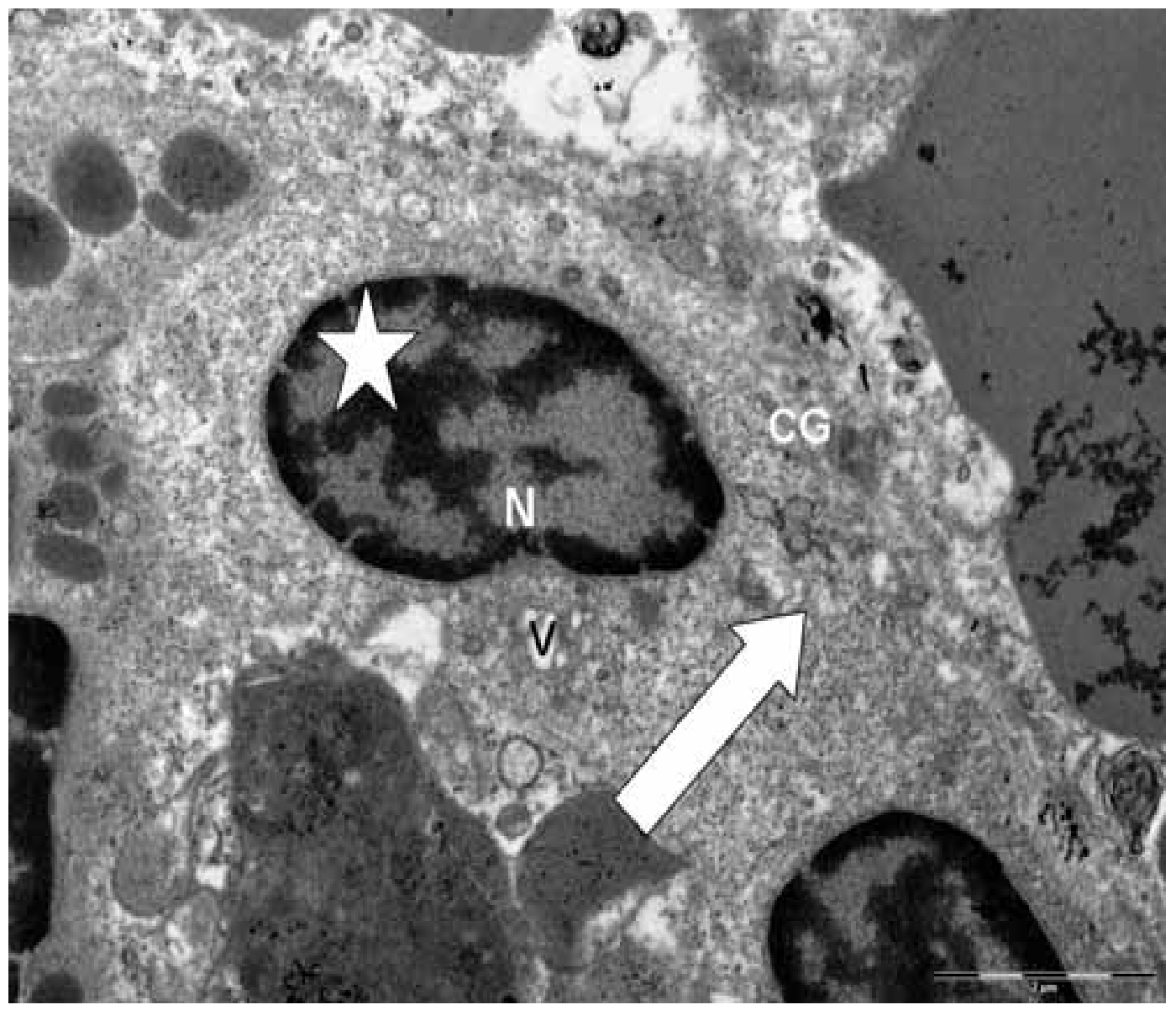

Figura 29 - Eletromicrografia de timócito. Célula com núcleo grande de formato irregular $(\mathrm{N})$, hetrorocromatico (estrela). Apresentando projeções na membrana citoplasmátiva (seta larga), vacúolos (V) e complexo de Golgi (CG) no citoplasma. Barra de $2 \mu \mathrm{m}$ 


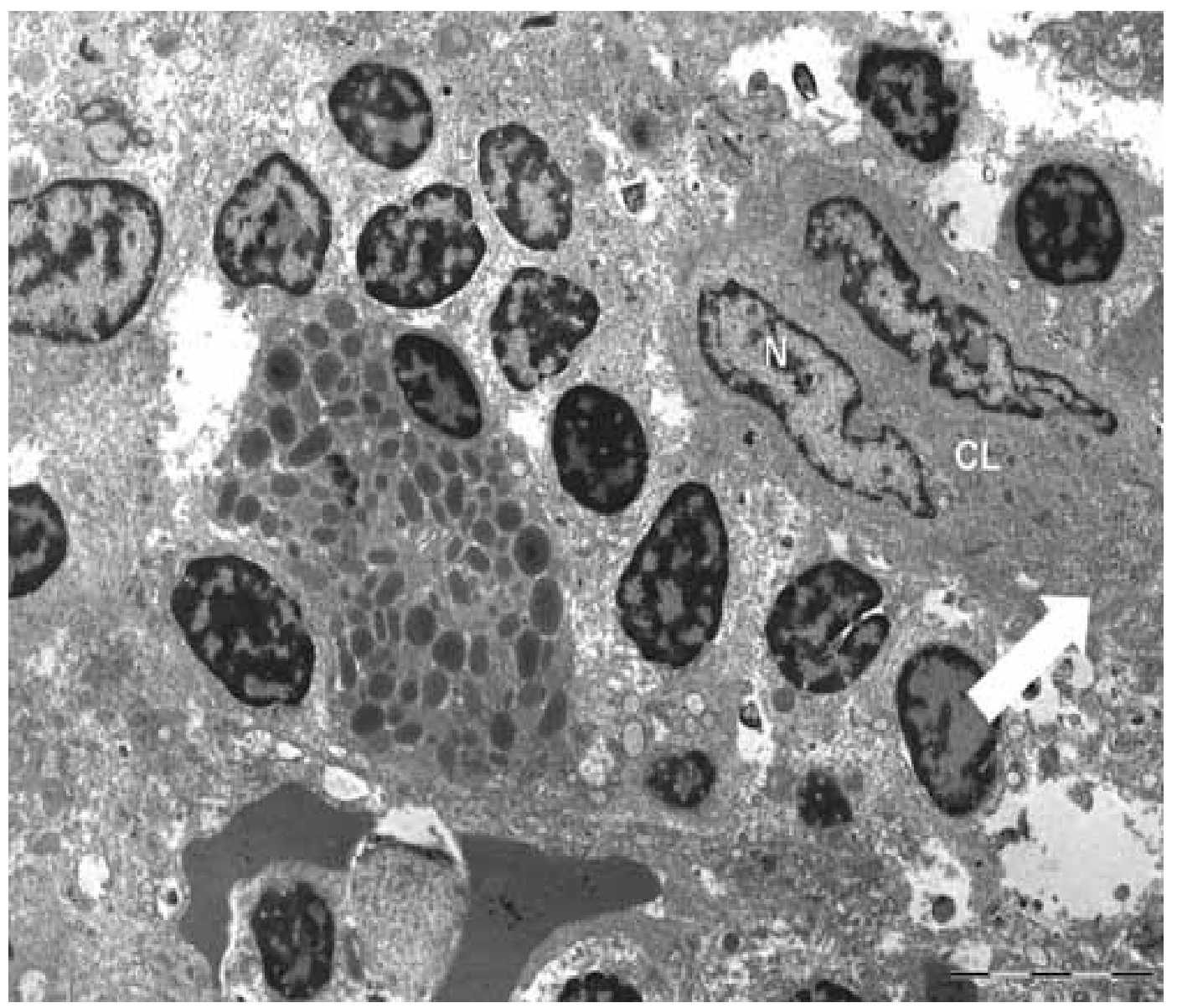

Figura 30 - Eletromicrografia de célula limitante no timo. Observar a forma irregular da célula (CL) com extensões citoplasmáticas (seta larga). Seu núcleo irregular acompanha a forma da célula $(\mathrm{N})$. Barra $2 \mu \mathrm{m}$ 


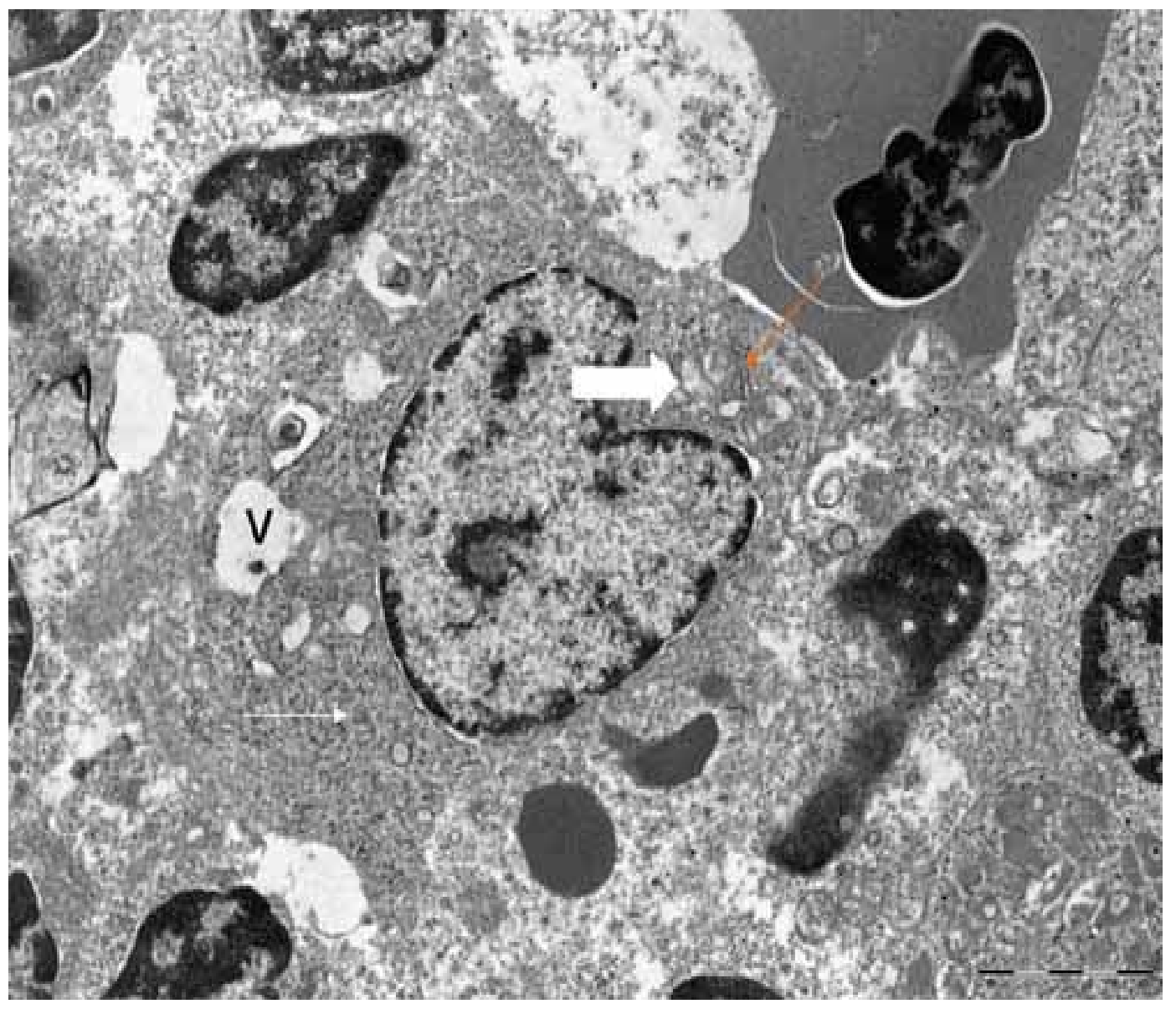

Figura 31 - Eletromicrografia de "nurse-cells". Observar vacúolos (V), vesículas com material flocular (seta larga) e pequeno complexo de Golgi (seta vermelha) dispersos no citoplasma . Barra de $2 \mu \mathrm{m}$ 


\subsubsection{Baço}

No baço são observadas uma polpa branca e uma polpa vermelha (Figura 32A). A polpa branca é formada por nódulos linfáticos constituídos por células imaturas, linfócitos e eosinófilos. A membrana deste nódulo é muito delgada, porém limita o espaço ocupado por eles no tecido conjuntivo.

A polpa vermelha constituiu-se num campo de células de hemácias e a polpa branca por nódulos linfáticos constituídos por infiltrados mononucleares.

Trabéculas, veias e artérias são observadas no parênquima envolvidas por tecido conjuntivo frouxo (Figura 32B).

São observados, dispersos no tecido conjuntivo da polpa vermelha vasos sangüíneos, melano-macrófagos livres, eosinófilos e linfócitos (Figura 33).

Ultraestruturalmente foram observadas vários tipos celulares. As células reticulares apresentaram um formato irregular com pequenas projeções citoplasmáticas, núcleo heterocromático e no seu citoplasma vesículas eletro-densas e mitocôndrias (Figura 34).

Esplenócitos se mostraram como células pequena com núcleo grande arredondado com heterocromatina condensada na membrana. Seu citoplasma era granular e não foi observada presença de organelas. Pode-se observar extensões celulares conectado a essas células a outras no parênquima (Figura 35).

Células limitantes foram observadas constituindo o parênquima envolvendo o que poderia ser uma "nurse cells". As células limitantes apresentavam um núcleo grande irregular heterocromático e sua forma parecia acompanhar a forma da célula (Figura 36). 

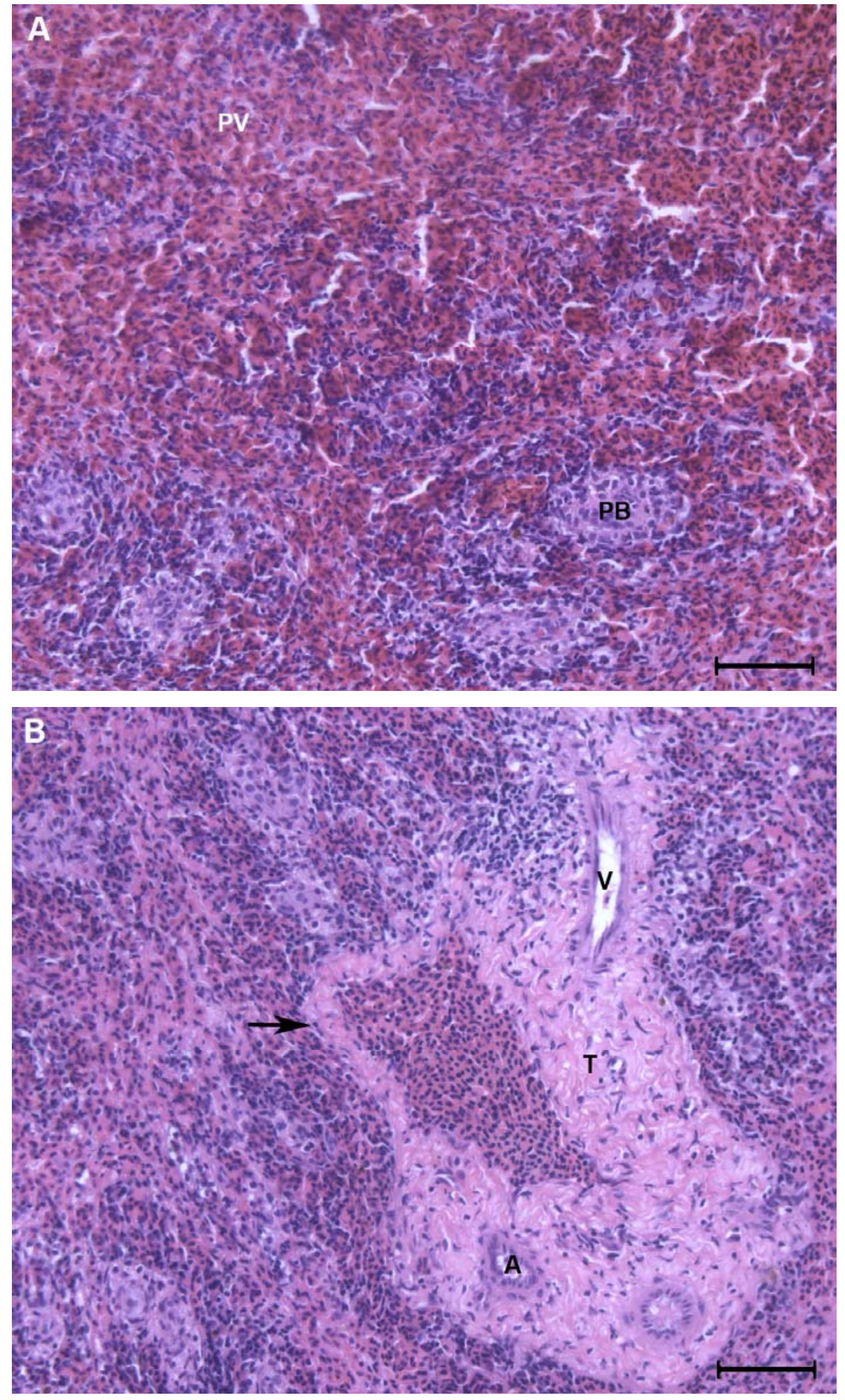

Figura 32 - Fotomicrografia. A: baço constituído por polpa branca (PB) e polpa vermelha (PV). Barra: $50 \mu \mathrm{m}$ B: trabécula ( $T$ ) dividindo o parênquima, constituída por tecido conjuntivo (seta), artérias (A) e veias (V). Coloração HE. Barra: $50 \mu \mathrm{m}$ 


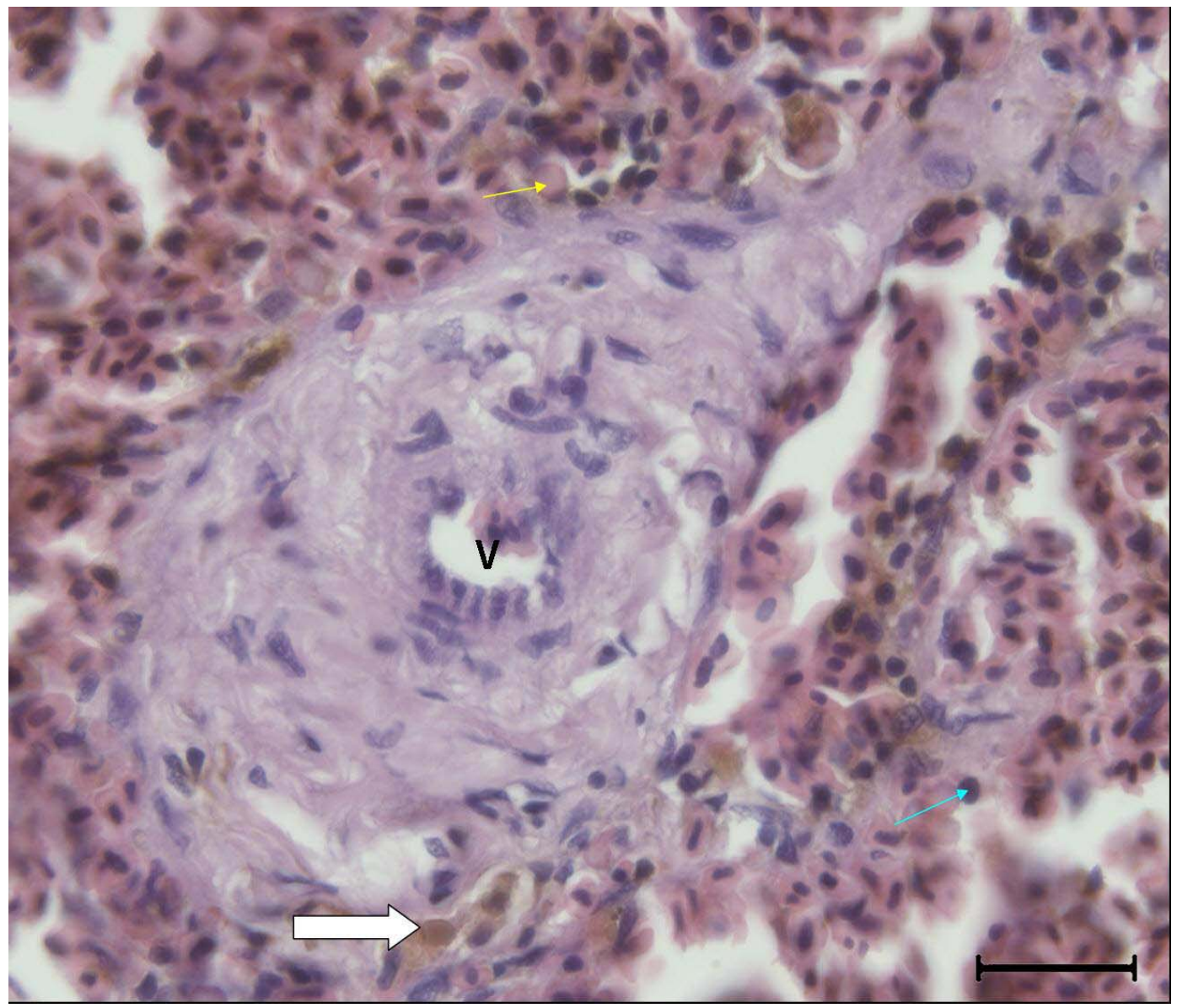

Figura 33 - Fotomicrografia de luz do parênquima do baço. Foram observados dispersos pelo parênquima vasos sanguineos (V), melanomacrófagos livres (seta branca), eosinófilos (seta amarela) e

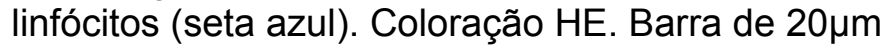




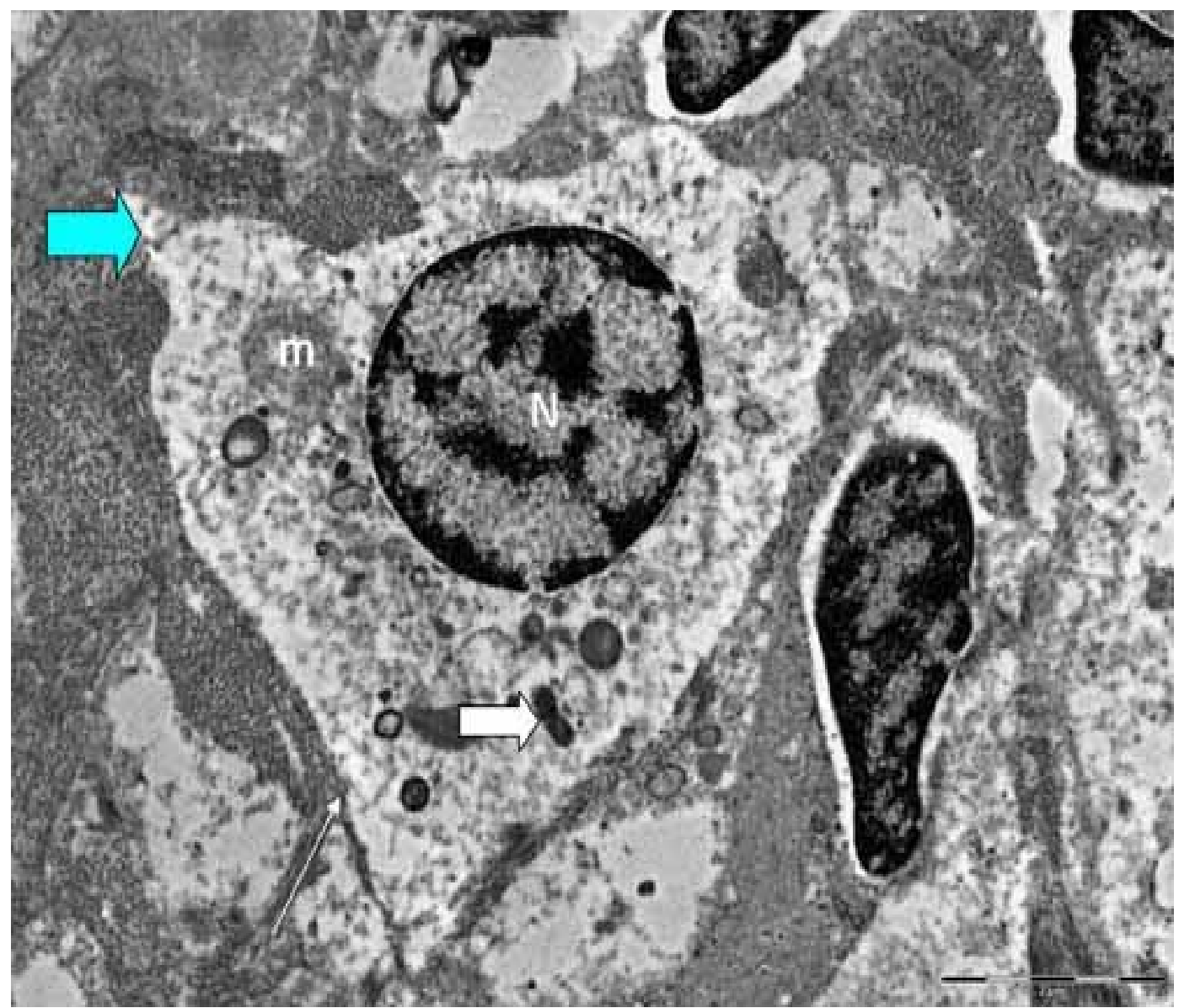

Figura 34 - Eletromicrografia de célula reticular do baço. Célula de formato irregular e pequenas projeções citoplasmáticas (seta azul), com núcleo grande heterocromático $(\mathrm{N})$. Observar no citoplasma mitocôndrias $(\mathrm{m})$ e material eletro-denso (seta branca). Barra de $2 \mu \mathrm{m}$ 


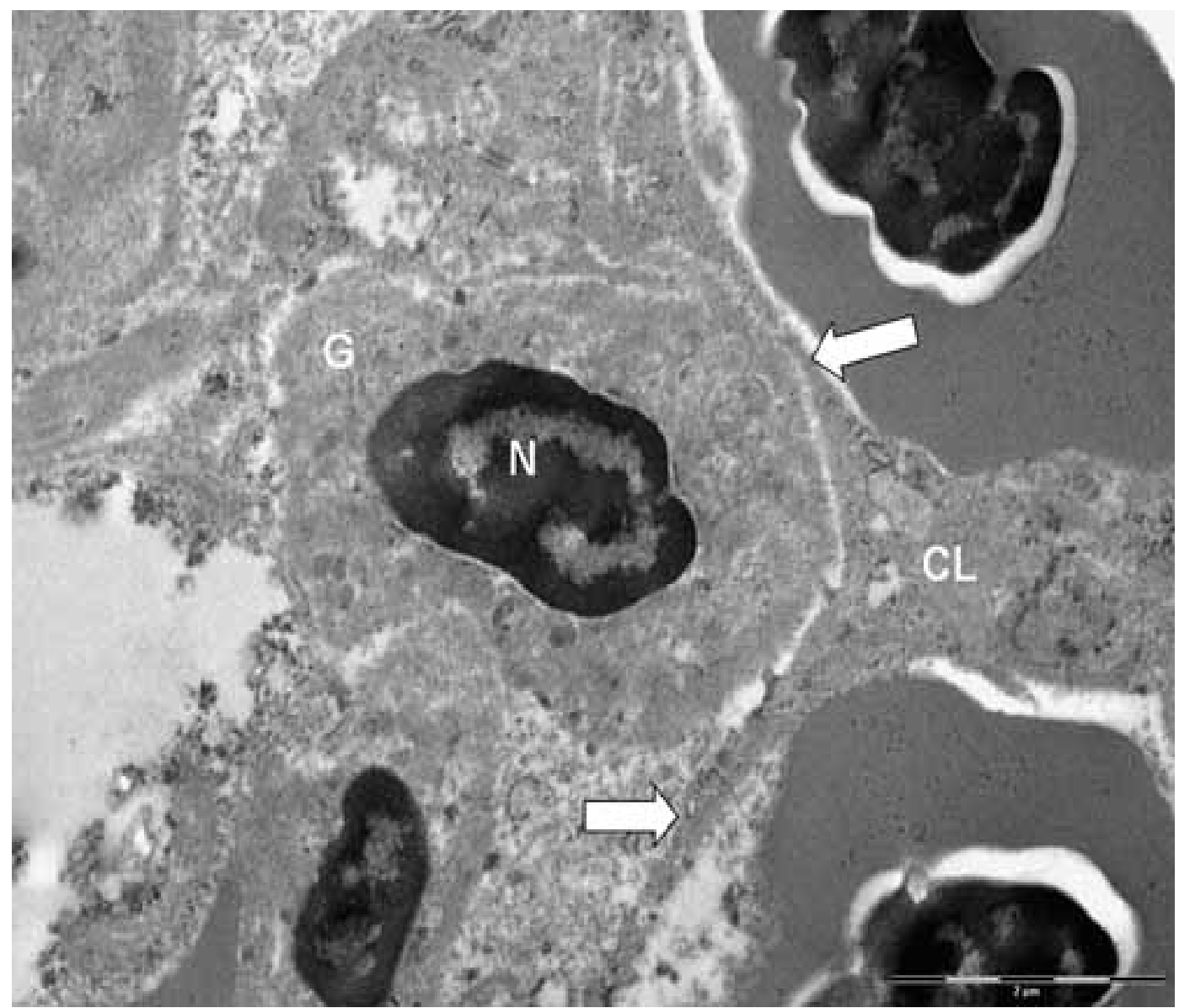

Figura 35 - Eletromicrografia de esplenócito. Observar a forma arredondada da célula, núcleo com cromatina condenada na membrana $(\mathrm{N})$ e citoplasma granular $(\mathrm{G})$. Observar extensões celulares de células limitantes (CL) conectando-as (seta). Barra $2 \mu \mathrm{m}$ 


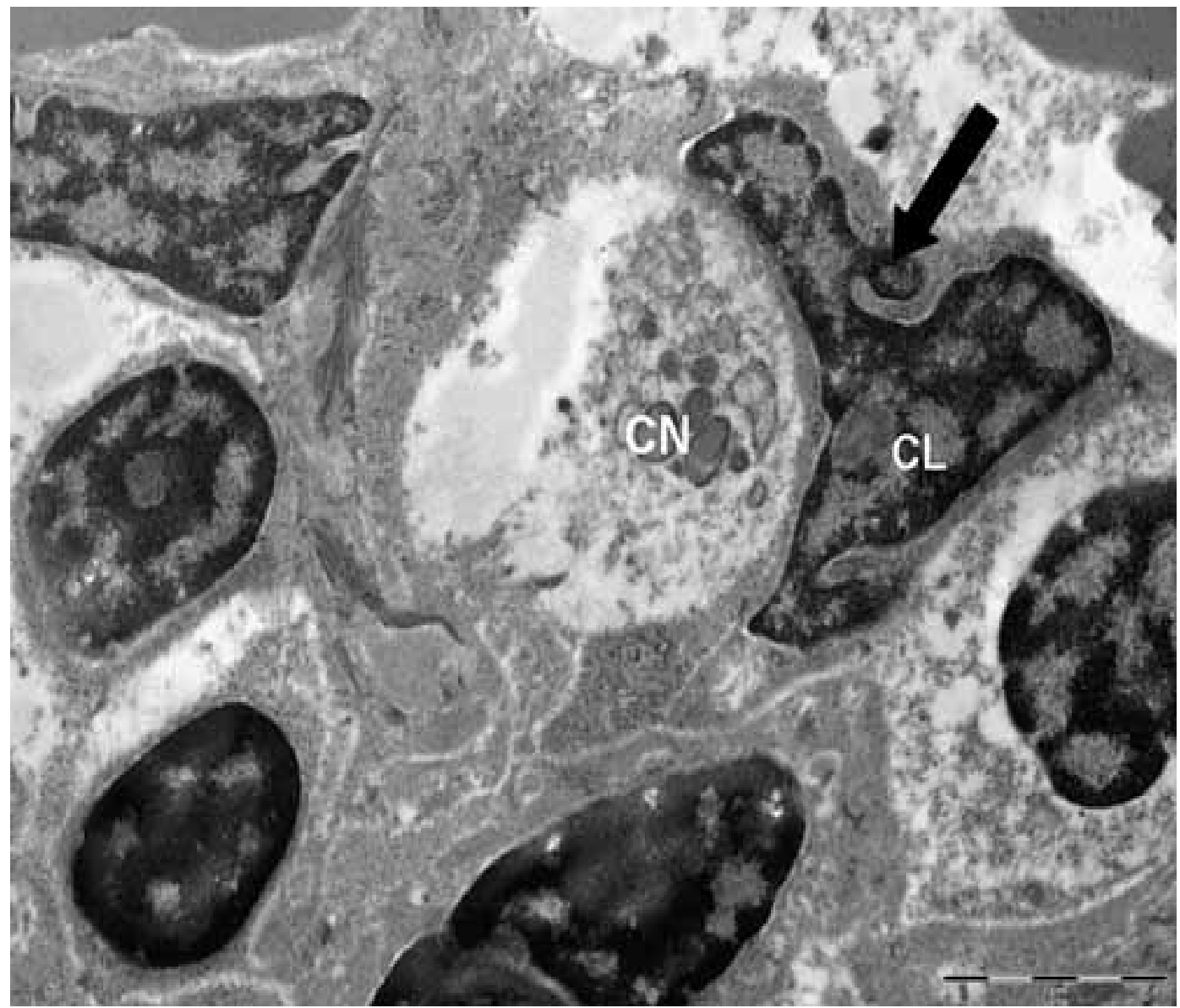

Figura 36 - Eletromicrografia de célula limitante no baço. Célula com forma irregular (CL) e núcleo heterocromático acompanhando a forma da célula (seta). Observar que a célula envolve uma "nurse cells" (CN). Barra de $2 \mu \mathrm{m}$ 


\subsubsection{Sangue}

Foi observado no sangue periférico de Piaractus mesopotamicus hemácias, trombócitos, células granulocíticas especiais, linfócitos, neutrófilos, monócitos, eosinófilos e células imaturas.

Pela microscopia de luz, as hemácias apresentam um formato ovalado, com núcleo central. Seu citoplasma se apresentou hialino e seu núcleo não apresentam granulação (Figura 37A). O tamanho das hemácias variou entre $12.21-14.16 \mu \mathrm{m} x$ 7.15 - $8.72 \mu \mathrm{m}$ (comprimento e largura), tendo o seu núcleo variado entre 5.07 $7.23 \mu \mathrm{m} \times 2.81-3.56 \mu \mathrm{m}$ (comprimento e largura).

Os trombócitos apresentam-se na forma elíptica, com núcleo grande e fusiforme. Seu citoplasma era hialino sem granulações (Figura 37A). O tamanho destas células nesta espécie variou entre $9.91-11.20 \mu \mathrm{m} \times 3.46-5.72 \mu \mathrm{m}$ e o núcleo em $6.55-8.35 \mu \mathrm{m} \times 2.58-3.38 \mu \mathrm{m}$.

Os linfócitos são células pequenas arredondas, com núcleo grande que ocupa quase todo espaço citoplástico, visualizado como uma fina luz na extremidade da célula, não tendo sido observado granulações no núcleo e citoplasma (Figura 37A). Seus tamanhos variaram entre $4.33-6.11 \mu \mathrm{m} \times 4.32-6.57 \mu \mathrm{m}$

Eosinófilos são células grandes arredondas e com núcleo pequeno excêntrico. Observam-se granulações no seu citoplasma e núcleo. Seu citoplasma é basófilo, corando-se de azul ou violeta (Figura 37A). Apresentaram tamanho entre 11.11 - $13.93 \mu \mathrm{m}$ x 11.60 - $13.26 \mu \mathrm{m}$ e o núcleo em 4.31 - $7.17 \mu \mathrm{m}$ x 4.31 - 5.58 $\mu \mathrm{m}$.

As células granulocíticas especiais são células grandes redondas, que no sangue periférico desta espécie foi observado disperso entre as hemácias. Apresentam um núcleo redondo, localizado no ápice da célula sem grânulos. Seu citoplasma é hialino sem grânulos (Figura 37B), com tamanhos que variaram entre 13.18 - $14.23 \mu \mathrm{m}$ x 12.75 - $14.05 \mu \mathrm{m}$, com o núcleo variando entre 3.36 - $7.00 \mu \mathrm{m}$ x $3.83-6.92 \mu \mathrm{m}$.

Neutrófilos são células grandes de formato arredondado, contendo grânulos no citoplasma. O núcleo em forma de ferradura está localizado no ápice 
citoplasmático (Figura 37C) Apresentaram tamanhos entre $12.39-12.73 \mu \mathrm{m} \times 12.20$ $-12.89 \mu \mathrm{m}$.

Células imaturas não apresentam uma forma definida. Seu núcleo é grande e central sem grânulos, seu citoplasma hialino se cora levemente (Figura 37C). Essas células demonstraram variados tamanhos que ficaram entre $12.75-16.98 \mu \mathrm{m} \times 9.81$ $-15.18 \mu \mathrm{m}$, tendo o seus núcleos variando entre $5.15-7.98 \mu \mathrm{m} \times 3.72-8.26 \mu \mathrm{m}$.

Monócitos são células grandes que não apresentam uma forma definida, seu citoplasma é hialino e seu núcleo é grande e apresenta grânulação. Projeções citoplasmáticas com aparência de braços são visualizadas na membrana (Figura 37D). A medida destas células se mostrou entre $11.28-12.58 \mu \mathrm{m} \times 7.37-10.38$ e o núcleo com tamanhos de $6.42-7.27 \mu \mathrm{m} \times 4.35-5.44 \mu \mathrm{m}$. 

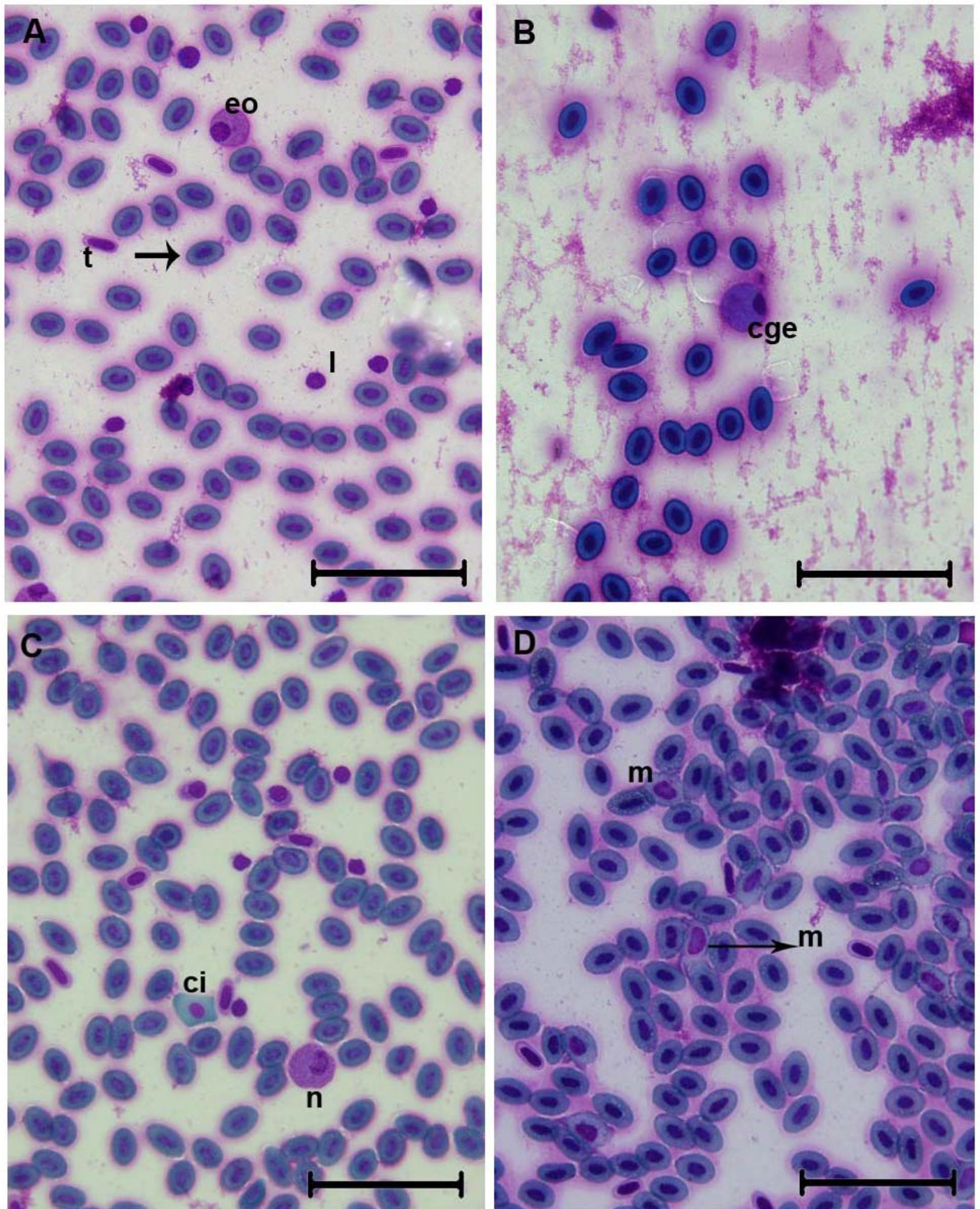

Figura 37- Fotomicrografia das células sangüíneas encontradas no sangue periférico de Piaractus mesopotamicus. A: eosinófilos (eo), trombócitos (t), hemácia (seta) e linfócito (I). B: célula granulocítica especial (cge). C: célula imatura (ci) e neutrófilo (n). D: monócito (m). Coloração de Panótico rápido. Barra: $20 \mu \mathrm{m}$ 


\section{DISCUSSÃO}

As observações macroscópicas realizadas em nosso trabalho tiveram por objetivo demonstrar a localização e anatomia do rim, rim cefálico, fígado, timo e baço de Piaractus mesopotamicus. As nossas análises nos mostraram muitas semelhanças destas estruturas com as de outras espécies de teleósteos e algumas diferenças encontradas no rim e o fígado desta espécie, que apresentam uma anatomia singular, a qual, até o momento, não foi descrita em outras espécies. Diferenças anatômicas entre os órgãos de diferentes espécies de peixes podem estar relacionadas à forma corpórea, hábitos alimentares, idade, stress e condições ambientais, variando entre espécies (BRUSLÉ e ANADON, 1996; ROCHA et al. 2001).

\section{$5.1 \mathrm{RIM}$}

A localização do rim de Piaractus mesopotamicus na cavidade celomática é a mesma encontrada em outras espécies de teleósteos (FERGUNSON, 1995). A forma em " $\mathrm{H}$ " apresentada pelo rim de pacu demonstra uma região central que se expande lateralmente sobre a bexiga natatória e dela partem a porção cranial direita e esquerda do rim e caudalmente a porção caudal direita e esquerda. Estas características anatômicas não foram relatadas em outras espécies, assim como foram escassos relatos sobre anatomia e consistência do rim de peixes na literatura. Hibiya (1982) relatou que a forma do rim de peixes varia de acordo com a espécie e divide o rim de teleósteos em duas porções: rim cefálico e um corpo ou rim, assim como Ellis e Souza (1974) e Zapata (1979, 1981).

Macroscopicamente, não se notou uma separação clara entre o rim e o rim cefálico em animais jovens e uma descrição semelhante foi feita por Becker; Fishelson e Amselgruber (2001) em Cyprinus carpio. Em animais mais velhos a distinção entre os dois órgãos ficou evidente pelo fato do rim cefálico apresentar-se 
como uma dilatação do órgão, porém esta característica não foi observada em outros teleósteos.

As análises histológicas do rim de Piaractus mesopotamicus revelaram similaridades com o rim de outras espécies de teleósteos, apresentando em sua constituição glomérulos, túbulos contorcidos proximais e distais e vasos sanguíneos como descritos por Ellis e Souza (1974); Zapata (1979, 1981); Hibyia (1982) e Stoskopf (1993). Não foi observada presença de alça de Henle. Esta é um segmento delgado que liga o túbulo contorcido proximal ao túbulo contorcido distal (JUNQUEIRA; CARNEIRO, 2004). Tal observação corroborou com Stoskopf (1993) que relata a ausência da alça de Henle no rim de peixes.

\subsection{RIM CEFÁLICO}

Em nossas análises macroscópicas o rim cefálico de Piaractus mesopotamicus localizou-se na extremidade da porção cranial do rim, o que foi confirmado através da microscopia de luz. Esta localização do rim cefálico também foi observada em outras espécies de teleósteos (ELLIS et al., 1976; ZAPATA, 1980; ROCHA et al., 2001; BECKER; FISHELSON; AMSELGRUBER, 2001).

Não foi possível observar uma clara distinção entre o rim cefálico e o rim em animais jovens. Macroscopicamente, os dois órgãos se mostraram como uma única estrutura que compunha a porção cranial do rim. Entretanto, em animais com idade mais avançada, o rim cefálico apresentou-se como uma dilatação na extremidade da porção cranial do rim, se tornando bem evidente a região do rim cefálico e a porção cranial do rim. Este achado não foi descrito por outros autores em outros teleósteos.

O rim cefálico é considerado o principal órgão formador de células do sangue de teleósteos (BIELEK, 1981), composto por uma variedade de células hematopoiéticas em diferentes estágios de maturação ocupando o espaço extravascular, assim como macrófagos, melano-macrófagos centrais, células reticulares, fibras reticulares e células sangüíneas imaturas (ESTEBAN et al., 1989).

Em nossas analises histológicas o rim cefálico se mostrou como uma massa celular dividida em uma região medular e uma região cortical e apresentou, na região de transição entre o rim e o rim cefálico, a presença de túbulos contorcidos 
proximais e alguns túbulos distais, o que também foi observado por Zuasti e Ferrer (1988), Fergunson (1995) e Powell (2000) em peixes teleósteos. Este órgão se caracterizou por ser constituído de vários tipos celulares como linfócitos, macrófagos, eosinófilos, alguns melano-macrófagos livres e melano-macrófagos centrais, células sangüíneas em vários estágios de maturação e vasos sanguíneos. A camada de revestimento e os tipos celulares que o constitui são similares às descritas para outras espécies de peixes (CHILMONCZYK, 1978; MILLER et al., 1985; ZUASTI; FERRER, 1989; MESSEGUER; ESTEBAN; AGULLEIRO, 1991; ROCHA et al., 2000; ROCHA et al., 2001; MELA et al., 2006).

Uma camada de tecido adiposo unilocular foi observada no parênquima do órgão, não havendo nenhum relato a respeito desta arquitetura na literatura consultada. Camadas de gordura foram frequentemente observadas recobrindo os órgãos de animais com idade mais avançada próximo ao período reprodutivo, provavelmente este fato pode estar relacionado a acúmulo de energia para este período.

Zapata (1979); Quesada; Villeva e Angulleiro (1990), Messeguer et al. (1991); Power (2000) e Rocha et al. (2000) descreveram o rim cefálico de várias espécies de peixes e suas características histológicas são similares às encontradas em Piaractus mesopotamicus. O rim cefálico seria um centro de processamento e formação de células sanguíneas, apresentando a capacidade de alojar e diferenciar células precursoras (AL-ADHAMl; KUNS, 1976), contendo um alto número de células hematopoiéticas e fagocíticas (POWER, 2000).

Os melano-macrófagos centrais observados pela microscopia de luz se apresentaram como um aglomerado de células de coloração marrom dispersos no parênquima próximos de vasos sangüíneos no rim cefálico. Estas características morfológicas dos melano macrófagos são as mesmas descritas para outras espécies de peixes teleósteos (MESSEGER et al., 1991; RABITTO et al., 2005; MELA et al., 2006).

As células encontradas e analisadas pela microscopia eletrônica de transmissão incluem células tronco, protombócito, trombócitos, mielócitos, eosinófilos, linfócitos, neutrófilos, macrófagos e linfócitos as quais foram observadas no rim cefálico em diferentes espécies de peixes teleósteos e descritas por diversos autores. Nossa identificação foi realizada comparando as diversas descrições da literatura consultada. Existem muitas divergências entre os autores quanto à 
nomenclatura e classificação destas células pela análise morfológica, seja essa microscópica ou ultraestrutural.

Os eosinófilos encontrados são células grandes de formato arredondado irregular, apresentavam em seu citoplasma muitos grânulos, alguns vacúolos e mitocôndrias. Essa característica dos eosinófilos é muito similar às encontradas em mamíferos (ROITT, 1991; TIZARD, 2002). Suas organelas como mitocôndrias, vacúolos e grânulos de variados tamanhos observados em nossos achados eram semelhantes às descritas em peixes teleósteos, os quais foram relatados como semelhantes aos de mamíferos (ZUASTI, 1988; ESTEBAN et al., 1989, 1990; RABITTO et al., 2005; MELA et al., 2006).

Os monócitos-macrófagos foram descritos com esta nomenclatura por se tratar de um tipo celular que se encaixava nos dois tipos descritos na literatura. Segundo Tizard (2002), monócitos são células que se encontram no sangue circulante e macrófagos são células que se localizam nos tecidos, podendo ser observados na corrente sangüínea. $O$ fato de alguns autores terem descrito estes tipos celulares no rim cefálico está ligado ao fato de o rim cefálico ser um centro de processamento e formação de células sanguíneas (AL-ADHAMI; KUNS, 1976; BIELEK, 1981). Estas células em Piaractus mesopotamicus se apresentaram em formato arredondado alongado ou sem uma forma definida, com pequenas projeções na membrana citoplasmática. As características apresentadas pelo seu núcleo como reentrâncias e material granular condensado heterogeneamente na periferia e pelas organelas observadas em seu citoplasma como complexo de Golgi, grânulos, vesículas, mitocôndrias e vacúolos, são características similares deste tipo celular descritas em todas as espécies de peixes (ELLIS, 1976; FERGUNSON, 1976; BIELEK, 1980; HIGHTOWER et al., 1984; PETERS; SCHWARZER, 1985; TATNER, 1985; MESEGUER; ESTEBAN; AGULLEIRO, 1991). Em nossos estudos não foi possível analisar em que estágio de maturação se encontravam estas células.

Os protombócito imaturos e protrombócitos maduros observados em nosso trabalho apresentavam núcleo grande edentados ou em forma de ferradura com cromatina heterogênea condensada, numerosos vacúolos, reticulo endoplasmático e grânulos no seu citoplasma. Os protrombocitos imaturos e maduros foram classificados quanto a forma do núcleo, tipo de cromatina e organelas dispersas em seu citoplasma e nossas observações ultraestruturais eram similares aos destes 
tipos celulares descritos para Salmo gairdneri (TATNER, 1985), Sparus auratus (ZUASTI, 1988, 1989) Dicentrarchus labrax (ESTEBAN et al., 1989; MESEGUER; ESTEBAN; AGULLEIRO, 1991). Contudo os protrombócitos maduros de Dicentrarchus labrax apresentaram também alguns processos na membrana celular (ESTEBAN et al., 1989), o que não foi encontrado em nossas análises .

Os mielócitos encontrados no rim cefálico de Piaractus mesopotamicus eram células grandes com núcleo grande periférico, apresentando em seu citoplasma mitocôndrias arredondadas ou alongadas, retículo endoplasmático rugoso, vesículas e complexo de Golgi. A escassez de grânulos no citoplasma de algumas destas células poderiam caracterizá-las como um mielócito da série de promielócito heterofílco (MESEGUER; ESTEBAN; AGULLEIRO, 1991). Estas células são descritas na literatura dentro de séries granulopoiéticas, onde são classificadas de acordo com o seu estágio de desenvolvimento (ZUASTI, 1988). Em nossas análises consideramos a morfologia celular e organelas encontradas no citoplasma, mitocôndrias, grânulos, complexo de Golgi e vesículas e a maioria delas apresentava-se similar aos mielócitos descritos em peixes teleósteos (ZUASTI, 1988; MESEGUER; ESTEBAN; AGULLEIRO, 1991).

Em Piaractus mesopotamicus os linfócitos se apresentaram como pequenas células com pouco citoplasma granular onde foram observadas algumas mitocôndrias e raros vacúolos. Exibiam um núcleo grande, arredondado que ocupava quase toda célula, com cromátina condensada distribuída irregularmente por ele. Essas características encontradas no linfócito de Piaractus mesopotamicus são semelhantes às características descritas em todas as espécies de peixes (ELLIS, 1976; FERGUNSON, 1976; CHILMONCZYK, 1978; BIELEK, 1980; MILLER et al., 1985; ZUASTI; FERRER, 1989) e aos de mamíferos (ROITT, 1991).

Plasmócitos encontrados entre linfócitos e eosinófilos no rim cefálico se caracterizaram por serem arredondadas ou ovóides, com núcleo grande central e heterocromatina condensada na periferia. Apresentavam em seu citoplasma uma quantidade muito alta de retículo endoplasmático rugoso mitocôndrias, vesículas, grânulos e material eletro-denso. Estas característica ultraestruturais dos plasmócitos eram semelhantes às Salmo gairdneri (CHILLER et al., 1969), Cyprinus carpio (SMITH et al., 1970) Esox lucius (SAVAGE, 1983) e Dicentrarchus labrax (MESEGUER; ESTEBAN; AGULLEIRO, 1991). 


\subsection{FIGADO}

O fígado, em algumas espécies, pode se encontrar separado dos outros órgãos na cavidade celomática e em outras, ligado ao intestino, podendo ter o comprimento da cavidade celomática (FERGUNSON, 1995). Pode ser composto por dois a três lobos ou não apresentar lobação, variando de acordo com a espécie. A forma, tamanho e volume deste órgão variam entre espécies e estão adaptados ao espaço utilizado pelos outros órgãos viscerais (BRUSLÉ; ANADON, 1996; OSTRANDER, 2000; VINCENTINE et al., 2005; FISHELSON, 2006).

Em nossos estudos em Piaractus mesopotamicus o fígado está localizado cranialmente na cavidade celomática. Esta localização é a mesma descrita por Stoskopf (1993) para os teleósteos marinhos. Entre o fígado e a cabeça, existe uma membrana que o separa desta na cavidade celomática. Não foi encontrado relatos na literatura sobre esta membrana ou qualquer estrutura que separe a cavidade celomática da cabeça. O fígado mostrou-se constituído por três lobos. Segundo Bruslé e Anadon (1996), muitas espécies de teleósteos apresentam um fígado constituído por três lobos, entretanto o fígado de tilápia do Nilo é formado apenas por dois lobos (VINCENTINE et al., 2005).

No pacu, a vesícula biliar encontra-se dividida em três porções: uma porção cranial, localizada no lobo ventral do fígado; uma porção média, que apresentou um estreitamento na sua estrutura e está localizada dorsalmente ao estômago, e uma porção caudal que se localiza caudalmente ao estômago e ventralmente à bexiga natatória.

A microscopia de luz demonstrou que o fígado de Piaractus mesopotamicus apresenta um parênquima formado por um campo de hepatócitos poliédricos, arranjados na forma de cordões, não apresentando lobação e mostrando bem evidente uma tríade portal com um ducto, uma veia e uma artéria. Entretanto, a tríade se mostrou em alguns momentos formada por um ducto e duas veias. Este tipo de arranjo do parênquima e a forma dos hepatócitos foi observado em várias espécies de teleósteos (BRUSLÉ; ANADON; 1996; AKIYOSHI; INOUE, 2004). Sinusóides, veias centrais, melano-macrófagos centrais e livres e células dendítricas no interstício foram observadas constituindo o parênquima hepático. As veias centrais encontravam-se distribuídas por todo parênquima e algumas se mostraram 
associadas a um ducto. A forma e constituição apresentada pelo fígado de Piaractus mesopotamicus foi a mesma descrita para as várias espécies de teleósteos já estudadas (HINTON; NIPES; KENDALL, 1972; HINTON; POOL, 1976; ROCHA; MONTEIRO; PEREIRA,1994; BRUSLÉ; ANADON, 1996; ROCHA; MONTEIRO; PEREIRA, 1997; VINCENTINE et al., 2005), não havendo nenhum tipo de característica particular no fígado desta espécie. Alguns autores relataram que diferenças na forma do parênquima hepático estariam relacionadas com tipo de alimentação, estresse ou alterações no meio ambiente, como temperatura e poluição ambiental (HINTON; LAUREN, 1980; FREDELLO et al., 2001).

As tríades hepáticas normalmente constituídas, em mamíferos por um ducto, uma veia e uma artéria, no fígado do pacu eram formadas por um ducto e duas veias, característica que não foi descrito em outros teleósteos. (ARELLANO; STORCH; SARASQUETE, 1999) relatou em Solea senegalenses que sistema porta, ducto biliar e arteríolas hepáticas não estão agrupados juntos na tríade hepática. Esta forma de arranjo da tríade encontrada em nossas análises pode ter ocorrido também devido a direção em que foi realizado o corte histológico.

Os melano-macrófagos centrais e livres observados pela microscopia de luz são similares aos encontrados em outros órgãos e se mostraram semelhantes aos encontrados em outras espécies (FERGUNSON, 1995; MELA et al., 2006).

Células dendítricas ou células endoteliais (HACKING; BUDD; HODSON, 1977 ) interconectando os hepatócitos no espaço perisinusoidal, apresentaram um formato irregular, núcleo central com projeções citoplasmáticas. Células estruturalmente similares e localizadas nestes mesmos espaços foram classificadas como células Ito ou estreladas que têm a função de suporte e arranjo de parênquima (ROCHA; MONTEIRO; PEREIRA, 1997; ARELLANO et al., 1999).

Ultraestruturalmente os hepatócitos de Piaractus mesopotamicusse apresentaram um núcleo central arredondado com cromatina condensada na periferia. Retículo endoplasmático rugoso, grânulos, complexo de Golgi, mitocôndrias e vacúolos estavam dispersos em seu citoplasma. Estas características ultraestruturais são similares as encontradas em espécies como Solea senegalenses (ARELLANO; STORCH; SARASQUETE, 1999), Hoplias malabaricus (RABITTO et al., 2005; MELA et al., 2006) e bacalhau (FUJITA, 1985). Estes autores relataram em seus trabalhos que seus achados eram similares aos descritos em outras espécies, 
demonstrando desta forma que os hepatócitos de peixes pouco variam entre as várias espécies.

\subsection{TIMO}

O timo de peixes é um órgão par, localizado acima dos arcos branquiais, atrás da cápsula ótica (HIBIYA, 1982; CHILMONCZYK, 1992; BECKER; FISHELSON; AMSELGRUBER, 2001; FISHELSON, 2006). Este órgão parece não involuir na maioria dos peixes (CHILMONCZYK, 1992; FISHELSON, 1995; BECKER; FISHELSON; AMSELGRUBER, 2001), entretanto há relatos de sua involução (CHILMONCZYK, 1992; LIU et al., 2004).

Em nossos estudos macroscópicos o timo de Piaractus mesopotamicus se apresentou com um órgão par, localizando-se acima dos arcos branquiais, caudalmente no crânio e cranial ao rim cefálico, parecendo ser uma continuação deste órgão. Apresentou uma consistência gelatinosa e coloração vermelho escura. A localização do timo, consistência e cor se mostraram semelhantes às descritas por Yatsutake e Wales (1983) em peixes, por Stoskopf (1993) para a maioria dos peixes teleósteos e por Fishelson (2005) em Apogon annularis, Apogon cyanosoma e Apogon cookii. A localização descrita para o timo não deixa claro se ele, nas espécies estudadas, se encontrava no interior do crânio ou fixado acima dos arcos branquiais.

O timo de Piaractus mesopotamicus mostrou-se constituído histologicamente por concentrados mononucleares, Corpúsculos de Hassall, timócitos, vasos e células epiteliais.

Os concentrados mononucleares eram formados por timócitos e junto às células epiteliais e sangüíneas constituíam o parênquima, que se mostrava relativamente frouxo. Células linfóides diferenciadas ou timócitos foram observados por Manning (1994) dentro de uma rede de células epiteliais e um parênquima relativamente frouxo foi observado em carpa doméstica por Becker, Fishelson e Amselgruber, (2001), como o encontrado em nossas análises.

Os Corpúsculos de Hassall se apresentam constituídos por um epitélio simples de células achatadas, sendo observadas, no seu interior, células imaturas 
sofrendo divisão e eosinófilos. Os Corpúsculos de Hassall juvenis são constituídos por algumas células e uma única camada de células reticulares que as circundam. Com a idade e o crescimento dos corpúsculos, o número de reticulócitos ao redor aumenta (FISHELSON, 2006).

Não houve uma clara distinção entre região medular e cortical na maior parte do parênquima, porém, nas áreas onde se encontravam os Corpúsculos de Hassall e os infiltrados mononucleares, o parênquima se dividia e se formava uma região medular. Nestas áreas a região cortical se tornava evidente e era constituída por células sangüíneas e células epiteliais. Para Manning (1994) a região cortical é formada por células epiteliais, enquanto que a região medular é constituída por células linfóides diferenciadas. Entretanto, observações realizadas em várias espécies de peixes por Chilmonczyk (1992); Trede e Zon (1998); De e Pal (1998); Luer (1995) e Liu et al. (2004) mostraram que o timo dessas espécies não apresentavam uma zona córtico-medular distinta. Fergunson (1995); Fishelson (1995, 2006) e Bowden; Cook e Rombout (2005) relataram uma região medular em peixes teleósteos constituída por Corpúsculos de Hassall e infiltrados mononucleares como observado em Piaractus mesopotamicus. Gorgolon (1983) e De e Pal (1998) relataram que estas regiões cortico-medulares e estruturas do timo de peixes variam muito entre as espécies.

Trabéculas constituídas por tecido conjuntivo e vasos sangüíneos também estavam presentes no parênquima tímico. No timo de mamíferos trabéculas não fazem parte da constituição do órgão (JUNQUEIRA; CARNEIRO, 2004), entretanto Zapata; Chiba e Varas, (1996) observou esta estrutura em elasmobrânquios e Bowden; Cook e Rombout (2005) em teleósteos, confirmando nossos achados.

Uma intensa vascularização caracterizou este órgão em Piaractus mesopotamicus, o que também foi observado em várias espécies de peixes teleósteos (NAKANISHI, 1986; CHILMONCZYK, 1992; MANNING, 1994; ZAPATA; CHIBA; VARAS, 1996; TREDE; ZON, 1998; LIU et al., 2004; BOWDEN; COOK; ROMBOUT, 2005).

Ultraestruturalmente os timócitos, célula mais abundante do timo, como também relata Chilmonczyk (1992) em teleósteos, demonstraram extensões citoplasmáticas e organelas como ribossomos, vacúolos e um complexo de Golgi, similares às descritas para timócitos por Press e Evensen (1999); Becker rt al. (2001) e Fishelson (2006). Células estruturalmente similares aos timócitos 
encontrados em nossas análises foram classificadas também como células mielóides (CHILMONCZYK, 1992), linfócitos (ZAPATA; CHIBA; VARAS, 1996; XIE et al., 2006) ou células T imunoativas (FISHELSON, 2006), embora todas tenham a mesma função e desenvolvimento. Nós classificamos esta pequena célula como timócito, por se tratar de uma nomenclatura mais clássica e usual para as mesmas.

Células limitantes apresentaram um núcleo grande, alongado e irregular que acompanhavam o formato da célula. Seu citoplasma emitia projeções que as interconectavam entre si e as "nurse cells" do timo apresentavam grânulos eletro densos, vacúolos, vesículas e um pequeno complexo de Golgi. Estes tipos celulares eram ultraestruturalmente similares aos descritos para Stcyases sanguineus (GORGOLON, 1983), Salmo gairneri (CASTILLO et al., 1990), Solea solea (PULSFORD et al., 1991), Oncorhynchus mykiss (FLAÑO et al., 1996), Diplopus puntazzo (ROMANO et al., 1999) e Siniperca chuatsi (XIE et al., 2006). Estas células têm função imune, de arranjo de parênquima e de suporte.

\subsection{BAÇO}

O baço de Piaractus mesopotamicus localiza-se centralmente na cavidade celomática, entre o fígado, bexiga natatória e a porção média da vesícula biliar. Apresenta sua superfície lisa em animais jovens e lobada em adultos, com uma coloração vermelho escura e consistência firme. Caracteristicas similares a estas foram descritas por Liu et al. (2004) em Paralichthys olivaseus e Fishelson (2006) em Cardinal fish. Descrições detalhadas quanto a localização e forma do órgão foram escassas na literatura.

Histologicamente o baço de Piaractus mesopotamicus apresentou uma distinção bem óbvia da polpa branca e polpa vermelha, porém desorganizados. A polpa vermelha era constituída por um campo de hemácias, vasos sangüíneos, melano-macrófagos livres, eosinófilos e linfócitos e a branca por nódulos linfáticos formados por infiltrados mononucleares. Segundo Fishelson (2006) o baço de peixes teleósteos é similar ao de vertebrados maiores, com uma bem pronunciada separação entre uma polpa branca, constituída de tecido linfático, e uma polpa vermelha que contém uma rede de cordões celulares enrolados, rico em 
macrófagos, neutrófilos e eosinófilos. Esta característica de formação de parênquima foi também observada em nossos achados. No baço de Paralichthys olivaseus não há distinção entre polpa vermelha e polpa branca em animais jovens e adultos (LIU et al., 2004).

Trabéculas bem evidentes constituídas por tecido conjuntivo, veias e artérias foram observadas invaginando-se do epitélio de revestimento para o interior do órgão. Trabéculas são estruturas que fazem parte do parênquima esplênico de todos os mamíferos (BANKS, 1992; JUNQUEIRA; CARNEIRO, 2004) e são frequentemente encontradas no baço de teleósteos com constituição similar às observadas em Piaractus mesopotamicus (SAILENDRI; MUTHUKKARUPPAN, 1975; HIBIYA, 1982; ZATAPA;1982).

Melano-macrófagos livres foram observados presentes no parênquima da polpa vermelha. Em Trichogaster leeri e Xiphophorus maculatus os melano macrófagos foram observados em sua maioria envolvidos em uma cápsula celular fina (LEKNES, 2004, 2007). Em muitos teleósteos o baço contém numerosos elipsóides e grandes áreas de células brancas e melano-macrófagos centrais (ELLIS et al., 1976; MESEGUER et al., 1994; ROMANO et al., 2000). Em nossos achados só foi confirmada presença de melano-macrófagos livres, a presença de muitos vasos e leucócitos, o que mostra que o baço de Piaractus mesopotamicus é similar a de outras espécies de teleósteos estudadas até o momento.

Ultraestruturalmente células reticulares, células interdigitantes, linfócitos, melano-macrófagos e plasmócitos apresentaram forma e composição semelhantes às encontradas em outros órgãos. Esta classificação ultraestrutural foi baseada nas similaridades destas células com as mesmas observadas em outros órgãos devido a escassez de informação e descrição específica de células no baço de peixes.

\subsection{SANGUE}

Os tipos celulares observados no sangue periférico de Piaractus mesopotamicus foram hemácias, trombócitos, células granulocíticas especiais, linfócitos, neutrófilos, monócitos, eosinófilos e células imaturas. 
As hemácias ou células vermelhas constituíam a maior parte das células no sangue periférico. Apresentaram forma oval a alongada, com núcleo central sem granulação e citoplasma hialino. Segundo Fänge (1994) normalmente 98-99\% das células do sangue em peixes são de hemácias. O que se confirmou em nossas análises.

Os trombócitos foi o tipo celular, depois das hemácias, mais observado no sangue de Piaractus mesopotamicus e de acordo com Ueda et al., (1997), estas células representam $50 \%$ dos leucócitos circulantes no sangue dos peixes. A forma elíptica apresentada por eles em nossas análises, também foi relatada em Rhamdia quelen (jundiá) e Cichlasoma dimerus (TAVARES-DIAS et al., 2002). Entretanto diferentes formas são relatadas para trombócitos, que podem se apresentar fusiformes, em formas ovais, irregulares e que podem variar de arredondado a alongado (CANNON et al., 1980; CAMPBELL; 1988; FÄNGE, 1994; KFOURY JR., 1999; VÁSQUEZ; GUERREIRO, 2007). Para Tavares-Dias e Moraes (2004) os trombócitos são células predominantemente elípticas em teleósteos.

O tamanho dos trombócitos nesta espécie variou entre $11.20-9.91 \mu \mathrm{m} \times 5.72$ - $3.46 \mu \mathrm{m}$ e o núcleo em 8.35 - $6.55 \mu \mathrm{m}$ x 3.38 - $2.58 \mu \mathrm{m}$. Em Cichlasoma dimerus essas células demonstração tamanhos entre $8.9-8 \mu \mathrm{m} \times 2.1-2.7 \mu \mathrm{m}$ (VÁSQUEZ; GUERREIRO, 2007), os trombócitos de formato fusiforme em Dlcentrarchus labrax apresentaram tamanhos médios de $7.72 \pm 2.19 \mu \mathrm{m}$ (ESTEBAN, 2000). Esta variação demonstra que o tamanho dos trombócitos varia entre espécies.

Os linfócitos são células pequenas arredondas, com núcleo grande que ocupa quase todo espaço citoplasmático. A morfologia destes linfócitos se mostrou similar a descrita em Dicentrarchus labrax (ESTEBAN et al., 2000), em Rhamdia quelen (TAVARES-DIAS et al., 2002) e Cichlasoma dimerus (VÁSQUEZ; GUERREIRO, 2007), sendo semelhantes também aos que compõem as populações celulares de pequenos linfócitos observados em truta arco-iris (KFOURY JR., 1999). O tamanho dos linfócitos desta espécie não apresentou diferenças significantes quando comparadas as de outros teleósteos descritos na literatura (KFOURY JR., 1999; ESTEBAN, 2000; VÁSQUEZ; GUERREIRO, 2007).

As células granulocíticas especiais foram observadas dispersas entre as hemácias e se caracterizaram por ter um citoplasma hialino sem grânulos. Estas células apresentam similaridades morfológicas de forma e tamanho as descritas em Prochilodus scrofa (curimbatá) (RANZANI-PAIVA; GODINHO, 1983), Brycon sp. 
(pirapitinga do sul) (RANZANI-PAIVA, 1991), Brycon cephalus (TAVARES-DIAS, 2004), o hibrido tambacu (TAVARES-DIAS, 2004) e Rhamdia quelen (jundiá) (TAVARES-DIAS et al., 2004).

Os eosinófilos encontrados em Piaractus mesopotamicus apresentaram morfologia semelhante as de Aristichthys nobilis e Astronotus ocellatus (TAVARESDIAS; MORAES, 2004) e Cichlasoma dimerus (VÁSQUEZ; GUERREIRO, 2007). Estas células também se mostraram muito parecidas as de Salminus maxilosus (VEIGA et al., 2000), entretanto não apresentavam projeções citoplasmáticas. A forma descrita para eosinófilos de Piaractus mesopotamicus foi semelhante a descrita na literatura, contudo apresentou um tamanho celular maior do que eosinófilos de outras espécies (VÁSQUEZ; GUERREIRO, 2007).

A morfologia observada nos neutrófilos de Piaractus mesopotâmicos é muito semelhante a encontrada em neutrófilos de mamíferos (JUNQUEIRA; CARNEIRO, 2004), apesar de se assemelharem em alguns aspectos aos descritos para espécies como Rhamdia quelen (jundiá) (TAVARES-DIAS et al., 2002) e Salminus maxilosus (VEIGA et al., 2000) os nossos achados mostraram uma semelhança muito maior com neutrófilos de mamíferos.

A mesma morfologia descrita para células imaturas de Rhamdia quelen (TAVARES-DIAS et al., 2002) foi observada em Piaractus mesopotamicus.

A morfologia encontrada nos monócitos é semelhante a observada por Campbell (1988) os quais se apresentam como células grandes, mostrando ocasionalmente vacúolos no citoplasma com projeções na sua membrana. Seu núcleo ocupa menos de $50 \%$ da célula e tem formatos variados, frequentemente redondo e ocasionalmente oval. Para Tavares-Dias et al. (2002) os monócitos de Rhamdia quelen, são células predominantemente grandes, de forma arredondada com citoplasma basofílico, núcleo freqüentemente excêntrico, geralmente alongado, ocasionalmente esférico. Em Pimelodus maculatus, uma célula arredondada, com citoplasma basofílico, vacuolizado, núcleo excêntrico alongado a esférico foi denominado como célula monocitóide por Ribeiro (1978). 


\section{CONCLUSÕES}

As análises macroscópicas do timo e baço de Piaractus mesopotamicus revelaram que estes apresentam semelhantes com outros peixes.

$\mathrm{O}$ rim demonstrou forma em "H" que se expandia sobre a bexiga natatória, não descrito em outros teleósteos.

O rim cefálico se apresentou como uma dilatação na porção anterior do rim em animais com idade mais avançada, o que não foi observado em animais jovens.

A vesícula biliar apresentou uma morfologia particular, sendo muito extensa e dividida em três porções que se estendiam por toda cavidade celomática, não tendo sido encontrado relato similar na literatura a observada em Piaractus mesopotamicus.

O fígado era constituído por três lobos que formavam uma estrutura semelhante a uma asa.

Histologicamente todos os órgãos se mostraram similares aos de outras espécies.

O fígado apresentou o arranjo do parênquima em forma de cordões, semelhante ao de outras espécies de teleósteos.

Ultraestruturalmente, os tipos celulares encontrados foram semelhantes aos descritos na literatura para outras espécies de peixes, demonstrando não haver diferenças significativas na composição das organelas destas células.

Ficou evidenciada em nossos estudos uma grande divergência na nomenclatura e uma falta de consenso na classificação de tipos celulares. Evidenciando em alguns casos, a nítida impressão de que vários autores estavam descrevendo um mesmo tipo celular, com mesma função, localização, tamanho e forma com nomes diferentes.

O sangue do Piaractus mesopotamicus é compostos pelos mesmos tipos celulares encontrados em outras espécies de peixes teleósteos, segundo classificação e descrição usada para teleósteos neotropicais. 


\section{REFERÊNCIAS}

AFONSO, A.; ELLIS, A. E.; SILVA, M. T. The leucocyte population of the unstimulated peritoneal cavity of rainbow trout (Oncorhynchus mykiss). Fish and Shellfish Immunology, v. 7, p. 335-348, 1997.

AGIUS, C. Phylogenetic development of melano-macrophage centres in fish. Journal of Zoology, v. 191, p. 11-31, 1980.

AGIUS, C.; AGBEDE, S. A. An electron micorscopical study on the genesis of lipofuscin, melanin and haemosiderin in the haemopoietic tissues of fish. Journal of Fish Biology, v. 24, p. 471-488, 1984.

AKIYOSHI, H.; INOUE, A. Comparative histological study of teleost livers in relation to phylogeny. Zoological Science, v. 21, p. 841-850, 2004.

AL-ADHAMI, M. A.; KUNZ, Y. W. Hematopoietic centres in the developing angelfish Pterophyllum scalare (Curier and Valenciennes). Wilheim Roux's Archives, v. 179, p. 393-401, 1976.

ALMEIDA, G. S. C. Suplementação dietética de vitamina C, desenvolvimento e sanidade do Pacu (Piaractus mesopotamicus, Holmberg, 1887). 2003. 47p. Dissertação de Mestrado - Escola Superior de Agricultura Luiz de Queiroz, Piracicaba

ARELLANO, J. M.; STORCH, V.; SARASQUETE, C. Histological changes and copper accumulation in liver and gills of the Senegales Sole, Solea senegalensis. Ecotoxicology and Environmental Safety, v. 44, p. 62-72. 1999.

ARKOOSH, M. R.; KAATTARI, S. L. Development of immunological memory in rainbow trout (Oncorhynchus mykiss). I. An immunochemical and cellular analysis of 
the B cell response. Developmental and Comparative Immunology, v. 15, p. 279293, 1991.

BANKS, W. J. Histologia veterinária aplicada. 2.ed. São Paulo Editora Monole Ltda. 1992. 629 p.

BARREDA, D. R.; NEUMANN, N. F.; BELOSEVIC, M. Flow cytometric analysis of PKH26-labeled goldfish kidney-derived macrophages. Developmental and Comparative Immunology, v. 24, p. 395-406, 2000.

BECKER, K.; FISHELSON, L.; AMSELGRUBER, M. Cytological ontogenesis and involution of the thymus and head-kidney in juvenile and old domestic carp: is ageing in fish a chronological or growth-related phenomenon? Journal of Applied Ichthyology, v. 17, p. 1-13, 2001.

BEERLI, E. L.; LOGATO, P. V. R.; FREITAS, R. T. F. de. Alimentação e comportamento de larvas de pacu, Piaractus mesopotamicus (Holmberg, 1887). Ciências Agrotécnicas, v. 28, n. 1, p. 149-155, 2004.

BEHMER, O. A.; TOLOSA, E. M. C.; FREITAS-NETO, A. G. Manual de técnicas histológicas normal e patológica. São Paulo, Editora Edart. 1976. 456 p.

BIELEK, E. Developmental stages and localization of peroxidatic activity in the leucocyts of the three teleost species (Ciprinus carpio L.; Tince ince L.; Salmo gairdneri Richardson). Cell and Tissue Reserch, v. 220, p. 163-180, 1981.

BOWDEN, T. J.; COOK, P.; ROMBOUT, J. H. W. M. Development and function of the thymus in teleosts. Fish e Shellfish Immunology, v. 19, p. 413-427, 2005.

BRITISKI, H. A. Peixes de água do doce do Estado de São Paulo - Sistemática. In: BRANCO, S. M. (Ed.). Poluição e piscicultura, São Paulo. Cimissão Interestadual da Bacia Paraná-Uruguai, USP, Faculdade de Saúde Pública; Instituto de Pesca de São Paulo, 1970. P. 79-108. 
BRUSLÉ, J.; ANADON, G. G. The structure and function of fish liver. In: MUNSHI: J. S. D.; DUTTA, H. M. (Eds). Fish Morphology- Horizon of New Research. New Delhi, Calcutta, India. Oxford, IBH Publishing Co. Pvt. Ltd., 1996. P. 77-78.

CAMPBELL, T. W. Fish cytology and hematology. 1988. In: STOSKOPF, M. K. The Veterinary Clinics of North America. Small Animal Medicine. Tropical fish medicine. Philadelphia: W. B. Sounderes, 1988. P. 349-364.

CANNON, M. S.; MOLLENHAUER, H. H.; EURELL, T. E.; LEWIS, D. H.; CANNON, A. M.; TOMPFINS, C. H. An ultrastructural study of the leukocytes of the channel catfish, Ictalurus punctatus. Journal of Morphology, v.164, p. 1-23, 1980.

CASTAGNOLLI, N. Criação de peixes de água doce. Jaboticabal: FUNEP, 1992. P.189.

CASTAGNOLLI, N.; CYNIRO, J. E. P. Piscicultura nos trópicos. São Paulo. Ed. Manolo, 1986. P.152.

CASTILLO, A.; LÓPEZ-FIERRO, P.; ÁlVAREZ, P.; ZAPATA, A.; VILLENA, A. J.; RAZQUIN, B. E. Post-hatching development of the thymus microenviroment in the rainbow trout, Salmo gairdneri: and ultrastructural study. American Journal of Anatomy, v. 190, p. 200-307, 1991.

CESTAROLLI, M. A.; GODINHO, H. M.; VERANI, J. R.; BASILE-MARTINS, M. A.; FENERICH-VERANI, N.; LEITE, R. G. Observações sobre o comportamento do pacu, Colossoma nitrei (Berg, 1895), em tanque experimental. In: SIMPÓSIO BRASILEIRO DE AQÜICULTURA (3). 1984, São Carlos. Anais: São Carlos: ABRAq; Universidade Federal de São Carlos,1984. P. 537-545.

CHESTER, J.; PHILLIPS, J. C. The adrenal and interrenal glands, In: Pang, M. P.; Schreibman, E. C., eds. Vertebrates Endocrinology: fundamentals and biomedical implications. New York: Academic Press., 1986. P. 319-350.

CHILMONCZYK, S. The thymus of the rainbow trout Salmo gairdneri. .Light and electron microscopy study. Development and Comparative Immunology, v. 7, p. 59-68, 1984. 
CHILMONCZYK, S. The thymus of fish: development and possible function in the immune response. Annual Reviews of Fish Diseases, v. 2, p. 181-200, 1992.

CROCKER, P. R.; MORRIS, L.; GORDON, S. Novel cell surface adhesion receptors involved in interactions between stromal macrophages and haemopoietic cells. Journal Cell Science Supplement, v. 9, p. 185-206, 1988.

DANNEVIG, B. H.; LAUVE, A. M. C. L.; PRESS, C.; LANDSVERK, T. Receptormediate endocytosis and phagocytosis by rainbow trout head kidney sinusoidal cells. Fish and Shellfish Immunology, v. 4, p. 3-18, 1994.

DE, S. K.; PAL, S. G. Studies on a gobiid fish thymus. Journal Freshwater Biology, v. 10, p. $63-67,1998$.

ELLIS, A. E.; DE SOUSA, M. A. B. Phylogeny of the lymphoid system. I. A study of the fate of circulating lymphocytes in plaice. European Journal Immunology, v. 4, p. 338-343, 1974.

ELLIS, A. E. Leucocytes and related cells in the plaice, Pleuronectes platessa. Journal Fish Biology, v. 8, p. 143-156, 1976.

ELLIS, A. E. The leucocytes of fish: A review. Journal Fish Biology, v. 11, p. 453491, 1977.

ELLIS, A. E.; ROBERTS, R. J.; TYTLER, P. The anatomy and physiology of teleosts. In: ROBERTS, R. J. (Ed.) Fish patology. London: Bailliere Tindall, 1989. P. 13-55.

ELLESAESSER, C. F.; MILLER, N. W.; CUCHENS, M. A.; LOBB, C. J.; CLEM, L. W. Analysis of channel catfish peripheral blood leukocytes by bright-field microscopy and flow cytometry. Transactions of the American Fisheries Society, v. 114, p. 279-285, 1985. 
ESTEBAN, M. A.; MESEGUER, A.; GARCIA, A.; AGULLEIRO, A. Erythropoiesis and thrombopoiesis in the lead-kidney of the sea bass (Dicentrarchus labrax L.): An ultrastructural study. Archives Histology Cytology, v. 52, n. 4, p. 407-419, 1989.

ESTEBAN, M. A.; MESEGUER, J. Phagocytic defense mechanisms in sea bass (Dicentrarchus labrax L.): an ultrastructural study. Anatomy Receiver, v. 240, p.589 $-597,1994$.

EVANS, D. L.; CARLSON, R. L.; GRAVES, S. S.; HOGAN, K. T. Nonspecific cytotoxix cells in fish (Ictalurus punctatus). IV: Target cell binding and recycling capacity. Journal Immunology, v. 141, p. 324-332, 1984.

EVANS, D. L.; JASO-FRIEDMANN, I. Nonspecific cytotoxic cells as effectors of immunity in fish. Annuales Zoology, v. 29, p. 409-418, 1992.

FÄNGE, R. Blood cells, haemopoiesis and lymphomyeloid tissues in fish. Fish e Shellfish Immunology, v. 4, p. 405-411, 1994.

FÄNGE, R.; PULSFORD, A. The thymus of the angler fish, Lophius piscatorius (Pisces:Teleostei) - a light and electron microscopic study. In: Manning, M. J.; Tatner, M. F. (eds). Fish Immunology. Orlando, Academic Press, 1985. P 293-312.

FERGUSON, H. W. The relationship between ellipsoids and melano-macrophage centres in the spleen of turboy (Scophthalmus maximus). Journal of Comparative Pathology, v. 86, p. 377-380, 1976.

FERGUSON, H. W. Systemic pathology of fish. Library of Congress Cataloging in Publication Data: 1995. P. 263.

FERRAZ DE LIMA, C. L. B.; REIS, N. S.; CECCARELLI, P. S. Alterações histológicas do lábio inferior do pacu, Piaractus mesopotamicus, Hoelmberg, 1887 (Teleostei, Serrasalminae), submetido a ambientes com baixa de oxigenio dissolvido. Histologia de Peixes In: II SEMANA SOBRE HISTOLOGIA DE PEIXES.1995.Jabotocabal. 153p. 
FERRAZ DE LIMA, J. A. Recursos pesqueiros em ambientes imundáveis (Rio Cuiabá - Pantanal de Mato Grosso). In: ENCONTRO BRASILEIRO DE ICTIOLOGIA, 10. 1993. São Paulo. Anais: São Paulo: Sociedade Brasileira de Ictiologia; USP, Instituto Oceanográfico, 1993. P. $302-310$.

FISHELSON, L. Cytological and morphological ontogenesis and involution of the thymus in cichlid fishes (Cichlidae, Teleostei). Journal of Morphology, v. 223, p.175 $-190,1995$.

FISHELSON, L. Ontogenesis and functional metamorphosis of the head-kidney in bottomspawner and mouthbrooder cichlid fishes (Cichlidae,Teleostei). Journal of Morphology, v. 229, p.1-21, 1996.

FISHELSON, L. Cytomorphological alterations of the thymus, spleen, head-kidney, and liver in cardinal fish (Apogonidae, Teleostei) as bioindicators of stress. Journal of Morphology, v. 267, p. 57-69, 2006.

FLANO, E.; ÁLVAREZ, F.; LÓPEZ-FIERRO, P.; RAZQUIM, B. E.; VILLENA, A. J.; ZAPATA, A. G. In vitro and in situ characterization of fish thymic nurse cells. Develpmental Immunology, v. 5, p. 17-24, 1996.

FREDELLO, J. P.; RAQBI, A.; MATTEI, X.; VIALE, D.; MARCHAND, B. Quantification of macrophage aggregates in the liver of Mugil cephalus. Journal of Submicroscopy Cytology and Pathology, v. 33, p. $473-473,2001$.

FUGITA, H.; TAMARU, T.; MIYAGAWA, J. Fine structural characteristics of the hepatic sinusoidal walls of the goldfish (Carassius auratus). Archives Histology Japanse, v. 43, p. 265-273, 1980.

FUGITA, H.; TATSUMI, H.; BAM, T.; TAMURA, S. Fine structural characteristics of the liver of the cool (Gadus morhuamacrocephalus), with special regard to the concept of hapatoskeletal system formed by Ito cells. Cell and Tssue Research, v. 244, p. 63-67, 1986. 
GORGOLLON, P. Fine structure of the thymus in the adult cling fish Sicyases sanguineus (Pisces, Gobiesocidae). Journal of Morphology, v. 177, p. 25-40, 1983.

HACKING, M. A.; BUDD, J.; HODSON, K. The ultrastructure of the liver of rainbow trout : normal structure and modifications after chronic administration of a polychlorinated biphenyl Aroclor 1254. Canadiam Journal of Zoology, v. 56, p. 477491, 1977.

HIBIYA, T. Digestive system - Liver. In: An Atlas of Fish Histology: normal and pathological features. Tokyo: Kodansha Ltd, 1982. P.82-90,

HINTON, D. E.; LAUREN, D. J. Liver structural alterations accompanying chronic toxicity in fishes: potential biomarkers of exposure. In: MCCARTHY J. F., SHUGART L. R, (Ed.) Biomarkers of environmental contamination.Chelsea, UK: Lewis, 1990.P. $17-57$.

HINTON, D. E.; POOL, C. R. Ultrastructure of the liver in channel catfish Ictatalurus punctatus (Rfinesque). Journal of Fish Biology, v. 8, p. 209-219. 1976.

HINTON, D. E.; SNIPES, R.; KENDALL, M. W. Morphology and enzyme histochemistry in the liver of largemouth bass (Micropterus salmoides). Journal Fish Research, v. 29, p. 531-534, 1972.

IWAMA, G.; NAKANISHI, T. The fish immune system: organism, pathogen, and environment. Fish Physiology Series, 1996. v. 15, 380 p.

KITA, J.; ITAZAWA, Y. Microcirculatory pathways in the spleen of the rainbow trout Oncorhynchus mykiss L. Journal of Ichthyology, v. 37, p. 265-272, 1990.

KFOURY JR., J. R.; KURODA, A.; NAKAYASU, C.; FUKUDA, H.; OKAMOTO, N. Analysis of rainbow trout peripheral blood leucocytes separated by flow cytometry cell sorting. Fish Pathology, v. 34, p. 1-6, 1999. 
KFOURY JR., J. R.; NAKAYASU, C.;SOUZA, J. C. R.; OKAMOTO, N. Characterization of a monoclonal antiboby specific to rainbow trout thrombocytes. Journal of Experimental Zoology, v. 284, p. 309-316, 1999.

KOLLNER, B.; WASSERRAB, B.; KOTTERBA, G.; FISHIER, U. Evaluation of immune functions of rainbow trout (Oncorhynchus mykiss) - how can environmental influences be detected? Toxicology Letters, v. 131, p. 83-95, 2002.

LEKNES, I. L. Endocytosis of horse-spleen ferritin in the black tetra, Gymnocorymbus ternetzi, (Characidae: Teleostei). Acta Anatomica, v. 106, p. 195-198, 2004.

LEKNES, I. L. Melano-macrophage centres and endocytotic cells in kidney abnd spleen of pearl gouramy and platyfish (Anabantidae, Poeciliidae: Teleostei). Acta Histochemica, v. 109, p. 164-168, 2007.

LIU, Y.; ZHANG, S.; JIANG, G.; YANG, D.; LIAN, J.; YANG, Y. The development of the lymphoid organs of flounder, Paralichthys olivaceus, from hatching to 13 months. Fish and Shellfish Immunology, v. 16, p. 621-632, 2004.

LORENZI, T. F. Manual de hematologia propedêutica e clínica. São Paulo: MDSI, 1999. 641p,

LUER, C. A.; WALSH, C. J.; BODINE, A. B.; WYFFES, J. T. SCOTT, T. R. The elasmolnanch thymus anatomical, histological and preliminary functional characterization. Journal Experimental Zoology, v. 273, p. 342-354, 1995.

MAINWARING, G.; ROWLEY, A. F. Studies on granulocyte heterogeneity in elasmobranches. In: MANNING, M. J.; TATNER, M. F. (Eds). Fish immunology. Orlando Academic Press, 1985. P. 57-69.

MANNING, M. J. Fish. In: TURNER, R. J. (Ed.). Immunology: a comparative approach. Chichester: US. J. Wiley e Sons Ltd, 1994. P. 69-100. 
MARLASCA, M. J.; SANPERA. C.; RIVA, M. C.; SALA, R.; CRESPO, S. Hepatic alteration and induction of micronuclei in rainbow trout (Oncorhynchus mykiss) exposed to a textile effluent. Histology and Histopathology, Cellular and Molecular Biology, v. 13, p.703-712, 1998.

MATTY, A. J. The adrenal and the kidney hormones. In: MATTY, A. J., Fish Endocrinology. ed. Portland: Timber Press, 1985.P. 112-137.

MELA, M.; RANDI, M. A. F.; VENTURA, D. F.; CARVALHO, C. E. V.; PELLETIER, E.; OLIVEIRA RIBEIRO, C. A. Effects of dietary methylmercury on liver and kidney histology in the neotropical fish Hoplias malabaricus. Ecotoxicology and Environmental Safety, 2006.

MESEGUER, J.; ESTEBAN, M. A.; AGULLEIRO, B . Stromal cells, macrophages and lymphoid cells in the head-kidney of sea bass (Dicentrarchus labrax L.). An Ultrastructural study. Archives of Histology and Cytology, v. 54, n. 3, p. 299-309, 1991.

MICALE, V.; PERDICHIZZI, F. A quantitative and histochemical study on melanomacrophage centres in the spleen of the teleost Diplodus annularis $L$. Journal of Fish Biology , v. 37, p. 191-197, 1990.

NAKANISHI, T. Effects of X-radiation end thymectomy on the immune response in the marine teleost Sebasticus marmoratus. Developmental and Comparative Immunology, v. 10, p. 519-528, 1986.

NANDI, J. 1962. The structure of the interrenal gland in teleost fishes. In: FISHELSON, L. Cytomorphological Alterations of the Thymus, Spleen, Head-Kidney, and Liver in Cardinal Fish (Apogonidae, Teleostei) as Bioindicators of Stress. Journal of Morphology, v. 267, p.57-69, 2006.

NEUMANN, N. F.; BARREDA, D.; BELOSEVIC, M. Production of a macrophage growth factor(s) by a goldfish macrophages derived from goldfish kidney leukocytes. Developmental and Comparative Immunology, v. 4, p. 417-432, 1998. 
OSTRANDER, G.; BULLOCK, G.; BUNTON, T. The laboratory fish. 1. ed. San Diego. Academic Press, 2000. P. 678.

PETRERI JR., M. River fisheries in Brazil: a review. Regulated Rivers Research and Manegement, v. 4, p. 1-16, 1989.

PRESS, C. M. L.; DANNEVIG, B. H.; LANDSVERK, T. Immune and enzyme histochemical phenotypes of lymphoid and nonlymphoid cells within the spleen and head kidney of Atlantic salmon (Salmo salar L.). Fish Shellfish Biology, v. 4, p. 7993, 1994.

POWELL, D. B. Blood and lymphatic vessels. In: Ostrander, G. K. (Ed,) The laboratory fish. San Diego, USA: Academic Press, 2000. Chap 26. P. 441-448.

PULSFORD, A.; FANGE, R.; MORROW, W. J. M. Cell types and interactions in the spleen of the dogfish Scyliorhinus canicula L.: An electron microscopic study. Journal Fish Biology, v. 17, p. 649-662, 1982.

PULSFORD, A.; FÄNGE, R.; ZAPATA, A. G. The thymus microenviroment of the common sole, Solea solea. Acta Zoology, v. 72, p. 209-216, 1991.

QUENTEL, C.; OBACH, A. The cellular composition of the blood and haematopoietic organs of turbot Scophthalmus maximus L. Journal of Fish Biology, v. 41, p. 709716, 1992.

QUESADA, J.; VILLEVA, M. I.; ANGULLEIRO, B. Structure of the spleen in the sea bass (Dicentrarchus labrax): a light and electron microscopy study. Journal of Morphology, v. 206, p.273-281, 1990.

RABITTO, I. S.; ALVES COSTA, H. C.; SILVA DE ASSIS, É.; AKAISHI, F. M.; ANJOS, A.; RANDI, M. A. F.; OLIVEIRA RIBEIRO, C. A. Effects of dietary Pb (II) and tributytin on neotropical fish, Hoplias malabaricus: histopathological and biochemical findings. Ecotoxicology and Environmental Safety, v. 60, p. 147-156, 2005. 
ROCHA, E.; MONTEIRO, R. A. F.; PEREIRA, C. The liver of the trout, Salmo trutta fario: a light and electron microscope study. Journal of Anatomy, v. 185, p. 241249, 1994.

ROCHA, E.; MONTEIRO, R. A. F.; PEREIRA, C. Liver of the brown trout, Salmo trutta (Teleostei, Salmonidae): A stereological study at light and electron microscopic leves. The anatomical Record, v. 247, p. 317-328, 1997.

ROCHA, R. M.; LEME-DOS SANTOS, H. S.; VICENTINI, C. A.; DA CRUZ, C. Structural and Ultrastructural Characteristics of Interrenal Gland and Chromaffin Cell of Matrinxã, Brycon cephalus Gunther 1869 (Teleostei-Characidae). Anatomy Histology Embryology, v. 30, p. 351-355, 2001.

ROITT, I. M. Essencial Immunology, London, Oxford. Blackwell Scientific Publications, 1991, 356p.

ROMANO, N.; TAVERNE-THIELE, A. J.; FANELLI, M.; BALDASSINI, M. R.; ABELLI, L.; MASTROLIA, L.; MUISWINKEL, W. B. V.; ROMBOUT, J. H. M. W. Ontogeny of the thymus in a teleost fish, Cyprinus carpio L.: developing thymocytes in the epithelial microenvironment. Developmental and Comparative Immunology, v. 23, p. 123-137, 1999.

ROMBOUT, J. H. W. M.; VAN DE WAL, J. W.; COMPANJEN, A.; TAVERNE, N.; TAVERNE-THIELE, J. J. Characterization of a T cell lineage marker in carp, Cyprinus carpio L. Developmental and Comparative Immunology, v. 21, p. 35-46, 1997.

ROWLEY, A. F.; HUNT, T. C.; PAGE, M.; MAINWARING, G. Fish. In: ROWLEY, A. F. AND RATCLIFFE, N. A. (Eds.) Vertebrate blood cells. Cambridge: University Press Cambridge, 1988. P.19-127.

SAILENDRI, K.; MUTHUKKARUPPAN, V. R. Morphology of lymphoid organs in a Clichlid Teleost, Tilapia mossambica (Peters). Journal of Morphology, v. 147, p. 109-122, 1975.

SECOMBES, C. J.; FLETCHER, T. C. The role of phagocytes in the protective mechanisms of the fish. Annual Review of Fish Disease, v. 2, p. 53-71, 1992. 
SILVA, A. J. Aspectos de alimentação do pacu adulto, Colossoma mitrei (berg, 1985) (pisces, Characidae), no pantanal do Mato Grosso. 1985. 92 p. Dissertação (Mestrado em Ciências Biológicas) - Universidade Federal do Rio de Janeiro, Rio de Janeiro, 1985.

STAFFORD, J. L.; MCLAUCHLAN, P. E.; SECOMBES, C. J.; ELLIS, A. E.; BELOSEVIC, M. Generation of primary monocyte-like cultures from rainbow trout head kidney leukocytes. Developmental and Comparative Immunology, v. 25, n. 5-6, p. 447-459, 2001.

STEINHAGEN, D.; JENDRYSEK, S. Phagocytosis by carp granulocytes; in vivo and in vitro observations. Fish and Shellfish Immunology, v. 4, p. 521-524, 1994.

STOSKOPF, M. K. Fish Medicine. Philadelphia: W. B. Saunders Company, 1992, 882p,

TAVARES-DIAS, M.; MELO, J. F. B.; MORAES, G.; MORAES, F. R. Características hematológicas de teleósteos brasileiros. IV. Variáveis do jundiaí Rhamdia quelen (Pimelodidae). Ciência Rural, Santa Maria, v. 32, n. 4, p. 693-698, 2002.

TAVARES-DIAS, M.; MORAES, F. R. Hematologia de peixes teleósteos. Ribeirão Preto: Villimpress Complexo Gráfico, 2004.144 p.

TATNER, M. F. The migration of labeled thymocytes to the peripheral lumphoid organs in the rainbow trout, Salmo gairdneri Richardson. Developmental and Comparative Immunology, v. 9 p. 85-91, 1985.

TIZARD, I. R. Imunologia veterinária - Uma introdução. 6.ed., São Paulo. Editora Roca, 2002, 532 p.

TREDE, N. S.; ZON L. I. Development of T-cells during fish embryogenesis. Developmental and Comparative Immunology, v. 22, p. 253-263, 1998. 
TSUJI, T.; SENO, S. Melano-macrophage centres in the aglomerular kidney of the seahorse (Teleost): morphological studies on its formation and possible function. Anatomical Record, v. 226, p. $460-470,1990$.

UEDA, L. K.; EGAMI, M. I.; SASSO, W. S.; MATUSHIMA, E. R.Estudos hematológicos em Oreochromis niloticus (Tilápia) (linneus, 1758) (Cichlidae, teleostei). Brazilian Journal of Veterinary Research and Animal Science, v. 34:5, p.270-275, 1997.

VÁZQUEZ, G. R.; GUERRERO, G. A. Characterization of blood cells and hematological parameters in Cichlasoma dimerus (Teleoistei, Perciformes). Tissue and Cell, v. 39, p. 151-160, 2007.

VERMEULEM, G. J.; LAMBERT, J. G. D.; TEITSMA, C. A.; ZANDBERGEN, M. A. GOOS, H. J. T. Adrenal tissue in the male African catfish, Clarias gariepinus: localization and steroid hormone secretion. Cell and Tissue Research, v. 280, p. 653-657, 1995.

VENTURIERI, R. Pesque - Pague no Estado de São Paulo, São Paulo: Eco Associação para Estudos do Ambiente, 2002.151 p.

VINCENTINE, C. A.; FRANCESCHINI-VICENTINE, I. B.; BOMBONATO, M. T. S.; BERTOLUCCI, B.; LIMA, S. G.; SANTOS, A. S. Morphological study of the liver in the teleost Orechromis niloticus. International Journal of Morphology, v. 23, n. 3, p. 211-216. 2005.

WALSH, C. J.; LUER, C. A. Comparative phagocytic and pinocytic activities of leucocytes from peripheral blood and lymphomyeloid tissues of the nurse shark (Ginglymostoma cirratum, Bonaterre) and the clearnose skate (Raja eglanteria, Bosc). Fish and Shellfish Immunology, v. 8, p. 197-215, 1998.

YATSUTAKE, W. T.; WALES, J. H. Microscopic anatomy of salmonids; An Atlas. In: STOSKOPF, M. K. Fish medicine. Philadelphia: W. B. Saunders Company, 1992. 882p. 
YOAKIM, E. G.; GRIZZLE, J. M. Histological, histochemical and ultrastructural studies on the interrenal and chromaffin cells of the fathead minnow, Pimephales promelas Ratinesque. Journal Fish Biology, v. 17, p. 477-494, 1980.

YOFFEY, M. A contribution to the study of the comparative histology and physiology of the spleen, with reference chiefly to its cellular constituents. Journal of Anatomy, v. 63, p. 314-344, 1929.

YU, M. L.; SAROT, D. A.; FILAZZOLA, R. J.; PERLMUTTER, A. 1970. Effects of splenectomy on the immune response of the blue gourami, Trichogaster trichopterus, to infections pancreatic necrosis (IPN) virus. In: IWAMA, G.; NAKANISHI, T. The fish immune system: Organism, Pathogen, and Environment. v. 15, 1996, v. 15, 380p. (Fish Physiology series).

XIE, H. X.; ZHANG, Y. A.; SUN, B. J.; SUN, J.; YAO, W. J.; GAO, Q. Histologycal and cytological studies on the developing thymus of mandarin fish Siniperca chuatsi (Perciformes: Teleostei). Journal of Applied Ichthyology, n. 22, p. 125-131, 2006.

ZAPATA, A. Phylogeny of the fish immune system. Bulletin l'Institut Pasteur, v. 81, p. 165-186, 1983.

ZAPATA, A. Ultrastructural study of the teleost fish kidney. Developmental and Comparative Immunology, v. 3, p. $55-65,1979$.

ZAPATA, A.; CHIBÁ, A.; VARAS, A. Cell tissues of the immune system of fish. In Iwanma, G.; Nakanishi, T. editors. The fish immune system: organism, pathogen and environmental. San Diego:,academic Press, 1996a. p.255-287.

ZAPATA, A. G.; CHIBÁ, A.; VARAS, A. Cell tissues of the immune system of fish. In: IWANMA, G.; NAKANISHI, T. (Ed.). The fish immune system: organism, pathogen and environmental. San Diego:academic Press,1996b. p.1-62.

ZAPATA, A.; DIEZ, B.; CEJALVO, T.; GUTIÉRES-DE FRÍAS, C.; CORTÉS, A. Ontogeny of the immune system of fish. Fish e Shellfish Immunology, v. 20, p. 126-136, 2006. 
ZAPATA, A. G. Lymphoid organs of teleost fish.II. Ultrastructure of renal lymphoid tissue of Rutilius rutilius and Gobio gobio. Developmental and comparative Immunology, v. 5, p. 43-52, 1981.

ZUASTI, A.; FERRER, C. Granulopoiesis in the head kidney of Sparus auratus. Archives of Histology and Cytology, v. 51, n. 5, p. 425-431, 1988.

ZUASTI, A.; FERRER, C. Haemopoiesis in the head kidney of Sparus auratus. Archives of Histology and Cytology, v. 52, n. 3, p. 249-255, 1989. 